\title{
Methane Recovery from Animal Manures The Current Opportunities Casebook
}

P. Lusk

Resource Development Associates

Washington, DC

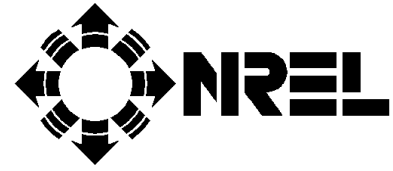

National Renewable Energy Laboratory 1617 Cole Boulevard Golden, Colorado 80401-3393

A national laboratory of the U.S. Department of Energy Managed by Midwest Research Institute for the U.S. Department of Energy under contract No. DE-AC36-83CH10093 


\section{Methane Recovery from Animal Manures \\ The Current \\ Opportunities Casebook}

P. Lusk

Resource Development Associates

Washington, DC

NREL technical monitor: A.E. Wiselogel

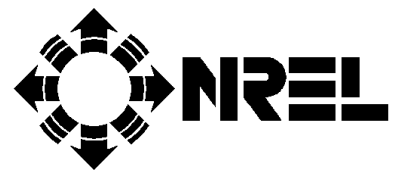

National Renewable Energy Laboratory 1617 Cole Boulevard

Golden, Colorado 80401-3393

A national laboratory of the U.S. Department of Energy Managed by Midwest Research Institute for the U.S. Department of Energy under contract No. DE-AC36-83CH10093

Prepared under Subcontract No. ECG-8-17098-01

September 1998 
This publication was reproduced from the best available copy Submitted by the subcontractor and received no editorial review at NREL

NOTICE

This report was prepared as an account of work sponsored by an agency of the United States government. Neither the United States government nor any agency thereof, nor any of their employees, makes any warranty, express or implied, or assumes any legal liability or responsibility for the accuracy, completeness, or usefulness of any information, apparatus, product, or process disclosed, or represents that its use would not infringe privately owned rights. Reference herein to any specific commercial product, process, or service by trade name, trademark, manufacturer, or otherwise does not necessarily constitute or imply its endorsement, recommendation, or favoring by the United States government or any agency thereof. The views and opinions of authors expressed herein do not necessarily state or reflect those of the United States government or any agency thereof.

Available to DOE and DOE contractors from:

Office of Scientific and Technical Information (OSTI)

P.O. Box 62

Oak Ridge, TN 37831

Prices available by calling (423) 576-8401

Available to the public from:

National Technical Information Service (NTIS)

U.S. Department of Commerce

5285 Port Royal Road

Springfield, VA 22161

(703) $605-6000$ or (800) 553-6847

or

DOE Information Bridge

http://www.doe.gov/bridge/home.html 


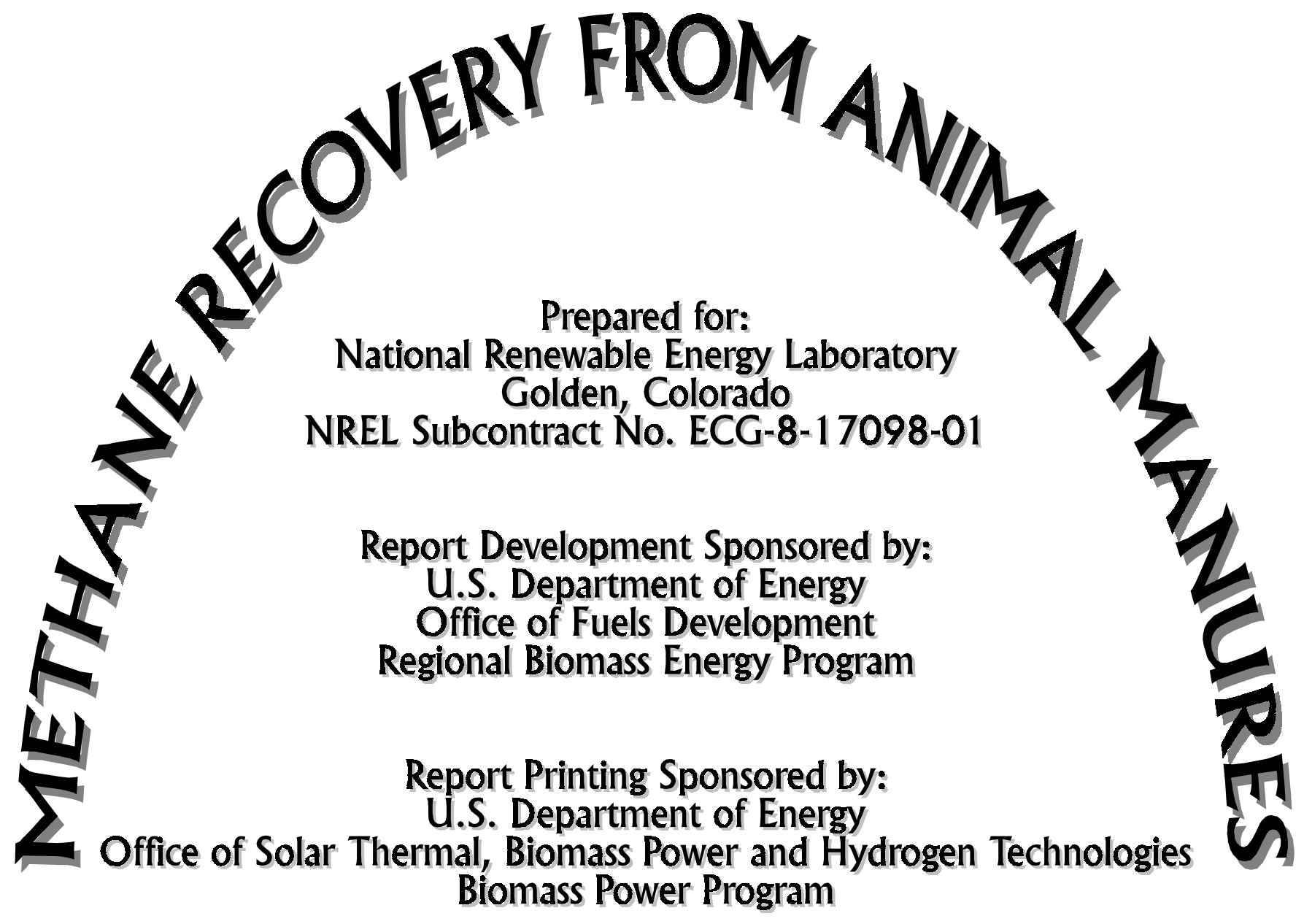

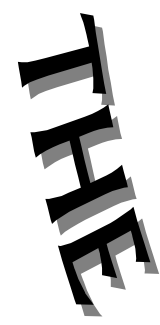

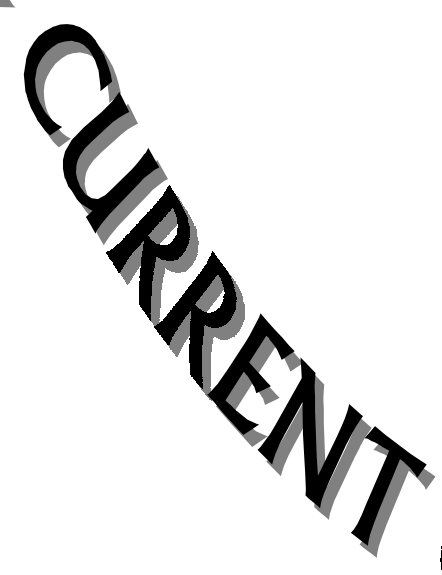

Prepared by:

Philip D. Lusk

Resource Development Associates

240 Ninth Street, NE

Washington, DC 20002-6110

tel: 202.546 .6283

fax: 202.546 .3518

email: plusk@pipeline.com

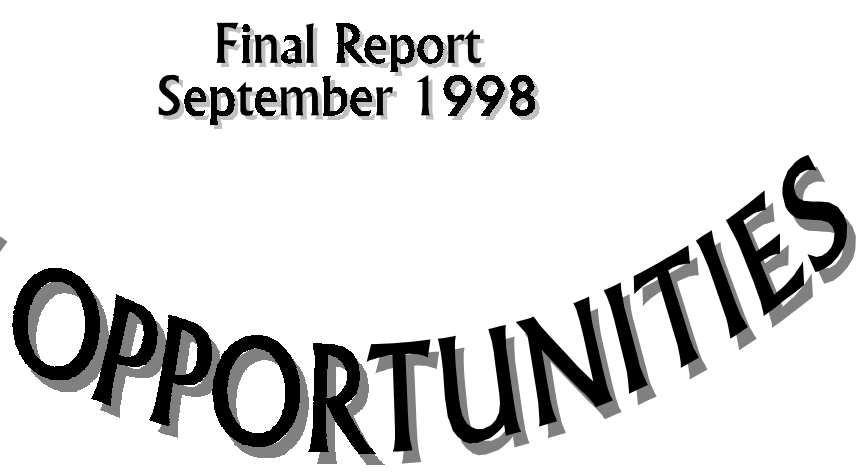




\section{TABLE OF CONTENTS}

$\underline{\text { PAGE }}$

\section{ABSTRACT}

Section 1.0

EXECUTIVE SUMMARY $1-1$

1.1 Status of Livestock Manure Anaerobic Digestion in the United States $1-1$

"Lessons Learned" $1-1$

Cautious Optimism

And What of the Future? $1-4$

3.1.1 Base Water Usage Cost and Energy Estimates

3.1.2 Base Water Usage Economic Evaluation 
TABLE OF CONTENTS (CONTINUED)

$\underline{\text { PAGE }}$

3.1.4 Reduced Water Usage Economic Evaluation ............................................. 3-8

Plug-Flow Digester Profile (.............................................................................. 3-9

3.2.1 Size and Product Estimates _............................................................. 3-10

3.2.2 Costs and Benefits Estimates ….............................................................. 3-13

3.2.3 Economic Evaluation ............................................................................ 3-14

Coproduct Utilization Illustration ...................................................... 3-17

3.3.1 1000-Head California Dairy with Covered Lagoon Digester ....................... 3-17

3.3.2 300-Head South Dakota Dairy with Plug-Flow Digester .............................. 3-18

3.3.3 10000-Head Nebraska Swine Farm with Complete-Mix Digester ............... 3-19

3.4 Other Economic Considerations .............................................................. 3-19

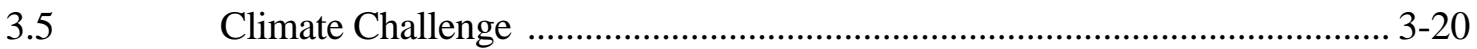

Economic Evaluation Summary …................................................... 3-22

Section $\quad 4.0 \quad$ CASE STUDIES OF ANAEROBIC DIGESTION PROJECTS ................... 4-1

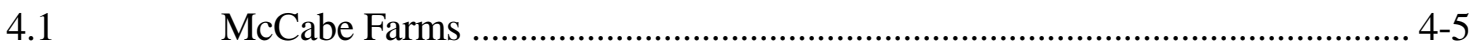

Not Publicly Identified …….................................................................... 4-8

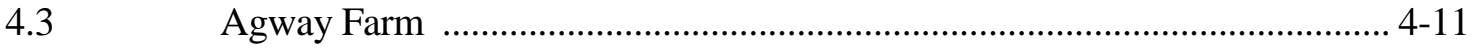

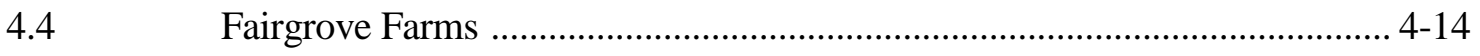

Foster Brothers Dairy Farm …................................................................ 4-17

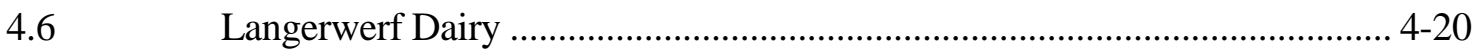

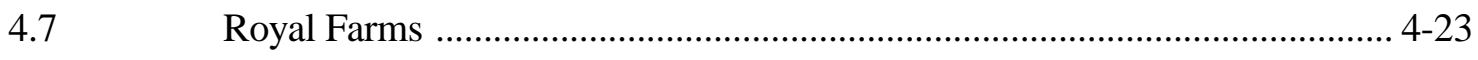

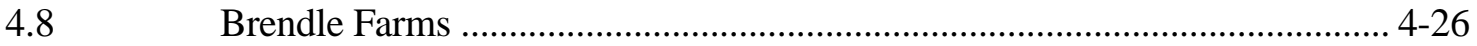


TABLE OF CONTENTS (CONTINUED)

$\underline{\text { PAGE }}$

4.9 Darrell Smith Farm

4.10 Oregon Dairy Farm 4-32

4.11 Cooperstown Holstein Corporation Farm 4-35

4.12 BTI Gonzales R\&D and Production Plant 4-38

4.13 Rocky Knoll Farm 4-41

4.14 Carroll's Foods, Inc. 4-44

4.15 Martin Farms $4-47$

Beltsville Agricultural Research Center ..... $4-50$

Craven Dairy Farms 4-52

Barham Farms 4-55

Cushman Dairy ...... 4-58

Freund Farm 4-60

AA Dairy. 4-62

Kirk Carrell Dairy....... 4-65

BTI-Noble Fertilizer Production Facility. 4-67 


\section{LIST OF TABLES}

$\underline{\text { PAGE }}$

Table 1.1

Table 2.1

Table 2.2

Table 2.3

Table 3.1

Table 3.2

Table 3.3

Table 3.4

Table 3.5

Table 3.6

Table 3.7

Table 3.8

Table 3.9

Table 3.10

Table 3.11
Status of Farm-Based Digesters in the United States $1-2$

Important Nitrogenic Compounds Derived from Agriculture .....

Effect of Fixed-Film Digestion at 3-day HRT on Flushed Dairy Manure Odor . $2-22$

Controlled Sanitation Equivalents to $158^{\circ} \mathrm{F}\left(70^{\circ} \mathrm{C}\right)$ for 1 Hour $2-23$

Macro CashFlow Variables 3-4

Covered Lagoon Digester Base Water Usage Economic Summary 3-6

Covered Lagoon Digester Reduced Water Usage Economic Summary

Plug-Flow Digester Hypothetical Outputs.

Plug-Flow Digester Air Emissions Estimator.

Plug-Flow Digester Capital Budgeting Summary $3-14$

Plug-Flow Digester Economic Summary 3-15

Plug-Flow Digester Financing Summary. 3-16 1,000-Head California Dairy Farm with Covered Lagoon Digester 3-18 300-Head South Dakota Dairy Farm with Plug-Flow Digester 3-19 10,000-Head Nebraska Swine Farm with Complete-Mix Digester 3-19 


\section{LIST OF FIGURES}

\section{PAGE}

Figure 2.1

Figure 3.1

Figure 3.2

Figure 3.3

Figure 3.4

Figure 3.5

Figure 3.6

Figure 4.1

Figure 4.2

Figure 4.2

Figure 5.1

Figure 5.2
The Anaerobic Digestion Process

. -1

Sensitivity of IRR and SPP to Electricity Rate for Base Water Usage

Swine Farm Covered Lagoon Digester with Heat Recovery

Sensitivity of IRR and SPP to Electricity Rate for Reduced Water Usage

Swine Farm Covered Lagoon Digester with Heat Recovery

Hypothetical Dairy Farm Plug-Flow Digester Outputs

Economic Sensitivity of Discount Rate to NPV Dairy Cow

Plug-Flow Digester.

Economic Sensitivity of Project Life to IRR Dairy Cow

Plug-Flow Digester.

Finance Sensitivity of Discount Rate to NPV Dairy Cow

Plug-Flow Digester.

Status of U.S. Farm-Based Anaerobic Digesters by System Type

Performance of U.S. Farm-Based Anaerobic Digesters

Status of U.S. Farm-Based Anaerobic Digesters by Installation Date

Supply Curve of Economically Recoverable Methane Emissions from Dairy and Swine Farms by Key States

Economically Recoverable Methane Emissions from Dairy and Swine Farms

by Regional Biomass Energy Program Area 5-8

\section{ACKNOWLEDGEMENTS}

Many thanks to the numerous persons contributing to the referenced studies, and especially to the individual system operators for their cooperation during site visits. Special recognition to Stefanie Woodward of NREL and Joan H. Ward of Resource Development Associates for editorial services. Also, much appreciation to Richard P. Mattocks of Environomics, Mark A. Moser of Resource Conservation Management, and Dr. Ann C. Wilkie from the Soil and Water Science Department of the University of Florida for their reviews and insightful comments.

Recommended Citation:

Lusk, P. (1998). Methane Recovery from Animal Manures: A Current Opportunities Casebook. 3rd Edition. NREL/SR-25145. Golden, CO: National Renewable Energy Laboratory. Work performed by Resource Development Associates, Washington, DC. 


\section{ABSTRACT}

Growth and concentration of the livestock industry create opportunities for the proper disposal of the large quantities of manures generated at dairy, swine, and poultry farms. Pollutants from unmanaged livestock wastes can degrade the environment, and methane emitted from decomposing manure may contribute to global climate change.

One management system not only provides pollution prevention but also can convert a manure problem into a new profit center. Economic evaluations and case studies of operating systems indicate that the anaerobic digestion (AD) of livestock manures is a commercially available bioconversion technology with considerable potential for providing profitable coproducts, including a cost-effective renewable fuel for livestock production operations.

This Casebook examines some of the current opportunities for the recovery of methane from the $\mathrm{AD}$ animal manures. U.S. livestock operations currently employ four types of anaerobic digester technology: slurry, plug-flow, complete-mix, and covered lagoon. An introduction to the engineering economies of these technologies is provided, and possible end-use applications for the methane gas generated by the digestion process are discussed. The economic evaluations are based on engineering studies of digesters that generate electricity from the recovered methane.

Case studies of operating digesters, with project and maintenance histories and the operators "lessons learned," are included as reality checks. Factors necessary for successful projects, as well as a list of reasons explaining why some AD projects fail, are provided. The role of farm management is key; not only must digesters be well engineered and built with high-quality components, they must also be sited at farms willing to incorporate the uncertainties of a new technology.

More than two decades of research has provided much information about how manure can be converted to an energy source; however, the American farmer has not been motivated to adopt new practices. More cost-effective and easily managed manure management techniques are still needed to encourage farmers to use animal manure for conversion into energy and nutrients, especially for smaller farms.

$\mathrm{AD}$ benefits farmers monetarily and mitigates possible manure pollution problems, thereby sustaining development while maintaining environmental quality. Moreover, rural economic development will benefit from the implicit multiplier effect resulting from jobs created by implementing digester systems. Promising future waste-to-profit activities may add to the economic performance of $\mathrm{AD}$. New end-use applications, which provide added value to coproducts, are discussed.

KEYWORDS: anaerobic digestion, bioconversion, engineering economy, environmental quality, pollution prevention, sustainable development. 


\subsection{EXECUTIVE SUMMARY}

Growth and concentration of the livestock industry in the United States create opportunities for the proper disposal of the large quantities of manures generated at dairy, swine, and poultry farms. The potential pollutants from decomposing livestock manures are biochemical oxygen demand (BOD), pathogens, nutrients, methane, and ammonia emissions. The major pollution problems associated with these wastes are surface and groundwater contamination and surface air pollution caused by odors, dust, and ammonia. There is also concern about the contribution of methane emissions to global climate change. Consequently, manure management systems that enable prevent pollution prevention and produce energy are becoming increasingly attractive.

The Casebook provides an examination of some current opportunities for the recovery of methane from the anaerobic digestion (AD) of animal manures. Case studies of operating digesters, with project and maintenance histories and the operators "lessons learned," are included as reality checks. Factors necessary for successful projects, as well as a list of reasons explaining why some $\mathrm{AD}$ projects fail, are provided. The role of farm management is key; not only must digesters be well engineered and built with high-quality components, they must also be sited at farms willing to incorporate the uncertainties of a new technology.

\subsection{Status of Livestock Manure Anaerobic Digestion in the United States}

This Casebook examines some of the conversion technologies employed to manufacture methane-rich biogas from the AD of animal manures. U.S. livestock operations currently use four types of anaerobic digester technology: slurry, plug-flow, complete-mix, and covered lagoons. The Casebook provides an introduction to digester technology and discusses possible end-use applications for the biogas product. Following the overview is a series of proforma economic evaluations, which are based on engineering studies of digesters that generate electricity from recovered biogas on dairy and swine farms with differing herd sizes. The economic evaluations and case studies indicate that the $\mathrm{AD}$ of livestock manures is a commercially available bioconversion technology with potential for providing profitable coproducts, including a renewable fuel for livestock production operations.

\section{2 "Lessons Learned"}

To provide a reality base to the economic evaluations, the Casebook surveys a number of operating and non-operating AD systems and compiles information on actual project and maintenance histories. Operators "lessons learned" offer insight into practical experience with digesters.

Table 1.1 provides a numerical status report of farm-based anaerobic digesters in the United States. The data presented include the digesters that are installed on or were planned for working dairy, swine, and caged-layer poultry farms. It excludes 65-70 digesters that are installed on or were planned for beef farms, and digesters that are primarily university research oriented. 
Table 1.1: Status of Farm-Based Digesters in the United States

Operating

Not Operating

Farm Closed

Under Construction/Planning Phase

Planned but Never Built

TOTAL

\begin{tabular}{|c|c|c|c|c|c|} 
Slurry & Plug & Mix & Lagoon & Other & TOTAL \\
\hline 7 & 8 & 6 & 7 & 0 & 28 \\
0 & 18 & 10 & 1 & 0 & 29 \\
0 & 11 & 5 & 1 & 0 & 17 \\
0 & 2 & 4 & 0 & 4 & 10 \\
0 & 8 & 1 & 1 & 0 & 10 \\
\hline 7 & 47 & 26 & 10 & 4 & 94 \\
\hline
\end{tabular}

The numerical status is not the whole story. Surveyed farmers who have installed and continue to operate digesters are generally satisfied with their investment decisions. Some chose to install digesters for non-economic reasons, primarily to control odor or contain excess nutrient runoff. Farmers have found that the returns provided from electricity and coproduct sales from the digester, however limited, are preferred to the sunk-cost of conventional disposal that provides zero return on investment. Moreover, without the environmental benefits provided by AD technology, some might have been forced out of livestock production. AD is sometimes the only technology that allows growth in the livestock production business. Turning a waste liability into a profit center that generates annual revenues can moderate the impacts of declining commodity prices and diversify farm income.

None of the farmers surveyed with an operating anaerobic digester said that they regret their basic decisions. Most would have preferred to spend less money on design and installation, but they are unsure of exactly how costs could have been cut. Many seek new ways to increase profitability by selling coproducts, primarily the digested solids. They would like additional assistance in determining how best to optimize the value-added coproducts. Beating the odds, a few have met the challenge of making their systems work despite bad design or equipment. The hard knock of practical experience makes them the true superstars of farm-based AD technology in the United States.

Still, at face-value, the performance data are not encouraging to a farmer considering whether to install an anaerobic digester as a waste treatment option. Overall, the chance for failure, i.e., having a non-operating anaerobic digester, is about 50\% in the United States. However, given the fairly dismal track records of other energy technologies ranging from synthetic fuels to other renewables, this level of performance is probably no better or worse than others that received government support during the energy crises of the 1970s.

Among the types of farm-based digesters actually built, the failure rates for complete-mix and plug-flow technologies are staggering; $70 \%$ and 63\%, respectively. For covered lagoon digesters, the failure rate is $22 \%$. Because there are fewer operating slurry digesters, their current $100 \%$ success rate is certainly inconclusive. Once slurry digesters have a larger market share, the opportunity for system failures caused by poor design, fabrication, and operation will be more equal to that of the other technologies, and the slurry digesters performance can then be gauged. 
One encouraging note is that reliability of the digesters constructed since 1984 is far better than for those constructed from 1972-1984. This is generally due to a more simplified digester design. Even more encouraging is the resurgence of interest in farm-based $\mathrm{AD}$ technology. For example, in the past 3 years 5 new systems were installed. Ten others are currently under construction or in a design phase. There is also some movement toward the development of centralized AD projects. Centralized systems might also be considered in areas where dairy, swine, or poultry farms are too small to support a cost-effective on-farm facility.

\subsection{Cautious Optimism}

Beyond their ability to manufacture biogas, digester designs based on use of thicker manures may offer the most benefits of the systems evaluated to date. When combined with a mechanical scraping system for manure collection, there is little added water compared to hydraulic flushing. Because the organic acids are not volatilized, the methane and odor associated with manure decomposition can be minimized to the greatest extent possible. Plug-flow digestion, and its Slurry cousin, are economically sensitive to coproduct use and other offsets from current manure management practices, but they are less expensive and technically easier to operate and maintain than a comparable complete-mix digester. Covered lagoon digesters appear to have economic merit for the large number of swine and dairy operations in the Southeast and West, which incorporate hydraulic flushing to collect manure and conventional anaerobic lagoons to treat waste. Complete-mix digesters generally have higher capital costs and operating and maintenance $(\mathrm{O} \& \mathrm{M})$ requirements than slurry-based, plug-flow, and covered lagoon digesters. This will generally limit complete-mix digester applications to very large farms or centralized facilities, or to farms having waste streams with total solid (TS) concentrations too low for slurry and plugflow digestion and to locations where the climate is too cold to economically justify covering an anaerobic lagoon.

The AD process is biologically based; therefore, each site must be individually evaluated and implemented. As a result, few meaningful generalizations can be made. Factors for successful project implementation include an adequate match of digester type to the farm's manure management program, competent design and installation (which simplifies digester O\&M), and maximizing coproduct use to enhance economic performance.

The list of reasons explaining why some AD projects fail must be headed by bad design or installation. When selecting the "best" qualified contractor to design or install an anaerobic digester system, an investor should rarely consider a firm without a significant amount of practical experience in the field. Poor equipment and materials selection is the second most common reason for failure. Although buying the best and most expensive equipment and materials available cannot guarantee project success, amortizing the cost of quality components over the life cycle of the project is a far better prospect than experiencing a failure resulting from the use of inferior products.

The role of farm management is key; not only must digesters be well engineered and built with high-quality components, they must also be sited at farms willing to incorporate the uncertainties of a new technology. 


\subsection{And What of the Future?}

The conversion of agricultural wastes, animal manures in particular, into a renewable energy resource has been the focus of intensive research for more than two decades. Much has been learned about how manure can be used as an energy and nutrient source. Several available digester systems are both cost-effective and easily managed; however, American farmers have not been motivated to adopt these new practices. More cost-effective and easily managed manure management techniques are still needed, especially for smaller farms, to encourage farmers to use animal manure for energy and nutrients.

Not only will farmers benefit monetarily, AD will also help mitigate animal manure's contribution to air, surface, and groundwater pollution. There are additional indirect benefits for rural economic development from the implicit multiplier effect resulting from the creation of jobs resulting from providing, installing, and maintaining the digester system equipment. The implicit multiplier effect of integrated agricultural production and processing can be 2-3 times the traditional production-only values.

Promising future waste-to-profit activities may enhance the economic performance of the overall farm manure management system. New end-use applications that can provide added value to coproducts and maximize nutrient utilization include advanced technologies to generate electricity and process heat; greenhouses; and, algae, plant and fish aquaculture. The use of attached greenhouses can also provide enhanced plant growth rates if the available carbon dioxide is captured. Wastewater effluent can also be discharged into ponds and used as a growth culture for high-protein content algae or other aquatic plants. A combination of these activities could be incorporated on farms with multi-function production systems. "Agri-Plex" would be a more accurate name for such an operation.

Extending the $\mathrm{AD}$ process to recover methane has considerable potential beyond the farm to other industries with a waste stream characterization similar to livestock manures. Example industries include processors of milk, meat, food, fiber, and pharmaceuticals. Some of these industries already recover methane for energy.

\subsection{Methane Recovery and the Climate Change Action Plan}

As a part of the methane emission reduction component of the Climate Change Action Plan ${ }^{1}$, the U.S. Environmental Protection Agency (EPA) and the U.S. Departments of Energy (DOE) and Agriculture (USDA) have expanded the voluntary AgSTAR pollution prevention program with the livestock industry. An AgSTAR livestock producer agrees to explore profitable methane reduction activities by signing a Memorandum of Understanding (MOU). With AgSTAR assistance, producers will survey farm facilities to identify profitable opportunities to capture and use methane. Producers will install systems for the recovery and use of methane only where it is profitable to do so.

1 Clinton, W.J.; Gore, A.C. (1993). Climate Change Action Plan. Washington, DC: Executive Office of the President. 
A recent survey of dairy and swine farms in the United States reaffirmed that AD is a technology with considerable potential. Assuming that the end-use of the biogas manufactured at these facilities is to generate electricity in internal combustion engines, two key factors determining digester profitability are farm size and electricity rates.

Ignoring caged layer poultry, the inventory of these economically recoverable emissions suggests that about $0.426 \mathrm{Tg}$ of methane are potentially recoverable from 3,000 dairy and swine farms in 19 states. Deploying digesters in just three key states (North Carolina, California, and Illinois) could potentially recover $79 \%$ of these methane emissions. This deployment level could basically meet the AgSTAR program's goal as defined in the President's Climate Change Action Plan.

Assuming that all recoverable methane emissions are converted into electricity at today's low efficiency rates suggests that slightly more than $165-\mathrm{mW}$ of new capacity could be brought online. Potentially more important, given methane's current global warming potential (GWP) of 21 , it represents a reduction in greenhouse gas emissions equivalent to the carbon dioxide emissions from about 3,500-mW of generating capacity from traditional fuels. To give some sense of scale, this represents about half of the current biomass-electric generating capacity in the United States. 


\subsection{INTRODUCTION TO ANAEROBIC DIGESTION}

Biogas is formed solely through the activity of bacteria, unlike composting in which fungi and lower creatures are also involved in the degradation process. Microbial growth and biogas production are very slow at ambient temperatures. They tend to occur naturally wherever high concentrations of wet organic matter accumulate in the absence of dissolved oxygen, most commonly in the bottom sediments of lakes and ponds, in swamps, peat bogs, intestines of animals, and in the anaerobic interiors of landfill sites.

The overall process of $\mathrm{AD}$ occurs through the symbiotic action of a complex consortium of bacteria, as shown by Figure 2.1.

FIGURE 2.1: The Anaerobic Digestion Process

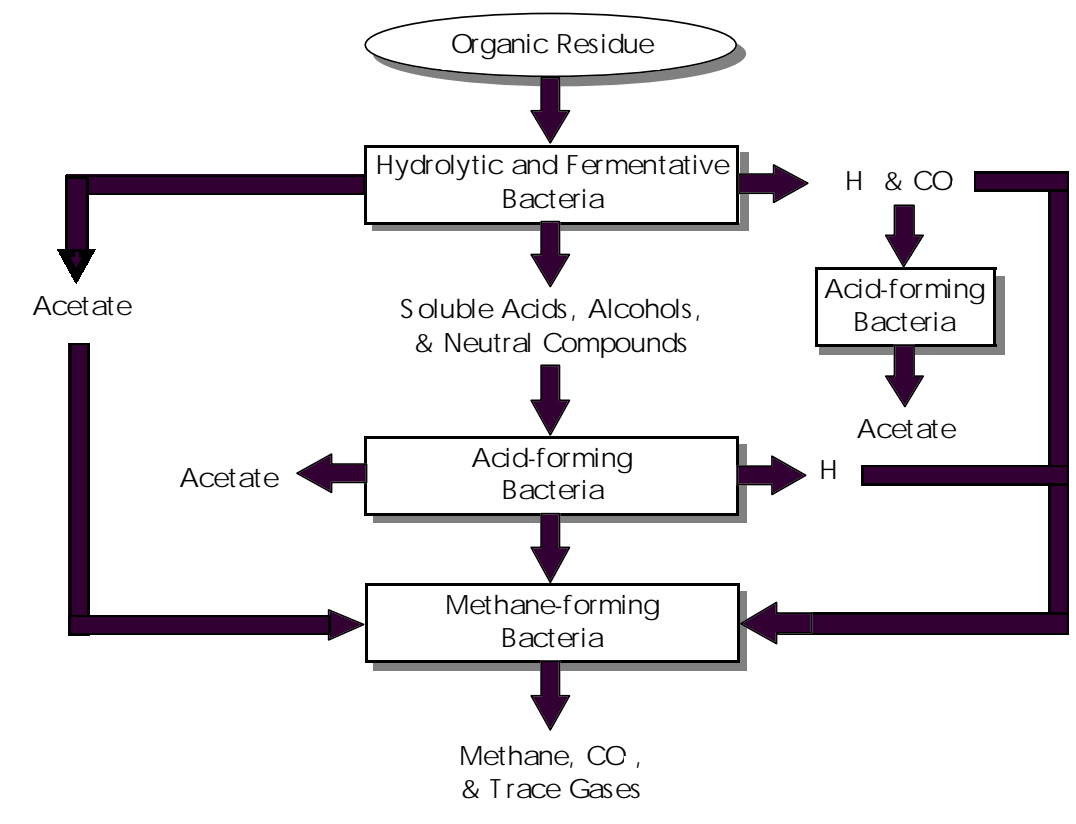
Hydrolytic microorganisms, including common food spoilage bacteria, break down complex organic wastes. These subunits are then fermented into short-chain fatty acids, carbon dioxide, and hydrogen gases.

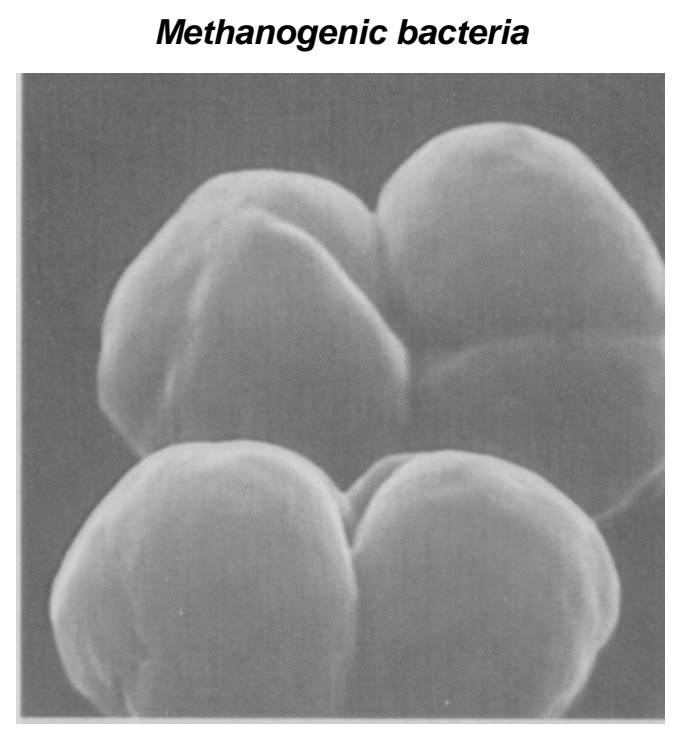

Syntrophic microorganisms then convert the complex mixture of short-chain fatty acids to acetic acid with the release of more carbon dioxide, and hydrogen gases. Finally, methanogenesis produces biogas from the acetic acid, hydrogen and carbon dioxide. Biogas is a mixture of methane, carbon dioxide, and numerous trace elements. According to some, the two key biological issues are determining the most favorable conditions for each process stage and how non-optimal circumstances affect each process stage as a whole, and the governing role of hydrogen generation and consumption. ${ }^{1}$

\footnotetext{
${ }^{1}$ Rivard, C; Boone, D. (1995). "The Anaerobic Digestion Process.” Second Biomass Conference of the Americas; August 21-24, 1995, Portland Oregon. Golden, CO: National Renewable Energy Laboratory, pp. 785790.
} 
Sulfate-reducing bacteria, which reduce sulfates and other sulfur compounds to hydrogen sulfide, are also present during the process. Most of the hydrogen sulfide reacts with iron and other heavy metal salts to form insoluble sulfides, but there will always be some hydrogen sulfide in the biogas.

The widespread natural occurrence of methane bacteria demonstrates that $\mathrm{AD}$ can take place over a wide temperature range from $40^{\circ} \mathrm{F}$ to more than $212^{\circ} \mathrm{F}$ and at a variety of moisture contents from around $60 \%$ to more than $99 \%$. This distinguishes the methane bacteria favorably from most aerobic microorganisms involved in the composting process.

$\mathrm{AD}$ occurs in the psychrophilic temperature range (less than $68^{\circ} \mathrm{F}$ ), and is routinely observed in marsh gas and in the ambient temperature lagoons used for livestock. Conventional anaerobic digesters, as will be explained in greater detail, are commonly designed to operate in either the mesophilic temperature range $\left(95^{\circ}-105^{\circ} \mathrm{F}\right)$ or thermophilic temperature range $\left(125^{\circ}-135^{\circ} \mathrm{F}\right)$.

There are usually two reasons why the mesophilic and thermophilic temperatures are preferred. First, a higher loading rate of organic materials can be processed and, because a shorter hydraulic retention time ${ }^{2}$ (HRT) is associated with higher temperatures, increased outputs for a given digester capacity result. Second, as will be discussed in more detail in Section 2.6, higher temperatures increase the destruction of pathogens present in raw manure.

\subsection{A Short History of Anaerobic Digestion}

Anecdotal evidence indicates that biogas was used for heating bath water in Assyria during the $10^{\text {th }}$ century BC and in Persia during the $16^{\text {th }}$ century. Jan Baptita Van Helmont first determined in $17^{\text {th }}$ century that flammable gases could evolve from decaying organic matter. Count Alessandro Volta concluded in 1776 that there was a direct correlation between the amount of decaying organic matter and the amount of flammable gas produced. In 1808, Sir Humphry Davy determined that methane was present in the gases produced during the AD of cattle manure.

The first digestion plant was built at a leper colony in Bombay, India in $1859 .{ }^{3}$ AD reached England in 1895 when biogas was recovered from a "carefully designed" sewage treatment facility and used to fuel street lamps in Exeter. ${ }^{4}$ The development of microbiology as a science led to research by Buswell ${ }^{5}$ and others in the 1930s to identify anaerobic bacteria and the conditions that promote methane production.

\footnotetext{
${ }^{2}$ n.b., HRT is the length of time that the average fragment of a feedstock like manure spends inside a digester.

${ }^{3}$ Meynell, P-J. (1976). Methane: Planning a Digester. New York: Schocken Books. pp. 3.

${ }^{4}$ McCabe, J; Eckenfelder, W. eds. (1957). Biological Treatment of Sewage and Industrial Wastes. Two volumes. New York: Reinhold Publishing.

${ }^{5}$ Buswell, A.M.; Hatfield, W.D. (1936). Bulletin 32, Anaerobic Fermentations. Urbana, IL: State of Illinois Department of Registration and Education.
} 
In the world of $\mathrm{AD}$ technology, farm-based facilities are perhaps the most common. Six to eight million family-sized, low-technology digesters are used to provide biogas for cooking and lighting fuels with varying degrees of success. In China and India, there is a trend toward using larger, more sophisticated systems with better process control that generate electricity.

In Europe, AD facilities generally have had a good record in treating the spectrum of suitable farm, industrial, and municipal wastes. The process was used quite extensively when energy supplies were reduced during and after World War II. Some AD facilities in Europe have been in operation for more than 20 years. More than 600 farm-based digesters operate in Europe, where the key factor found in the successful facilities is their design simplicity. Around 250 of these systems have been installed in Germany alone in the past 5 years.

Other factors influencing success have been local environmental regulations and
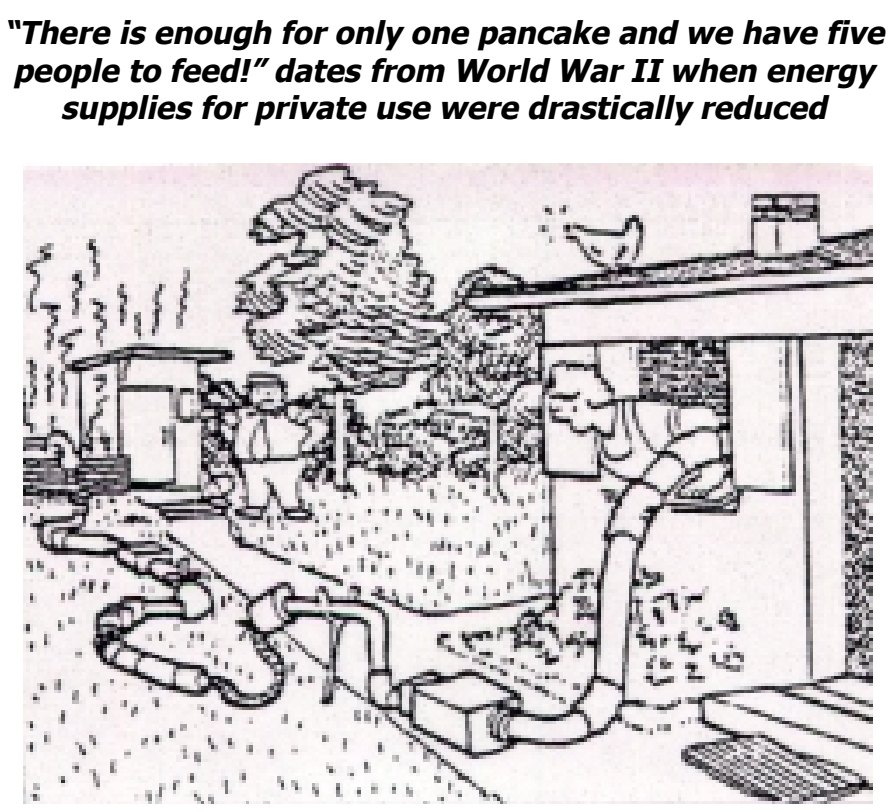
other policies governing land use and waste disposal. Because of these environmental pressures, many nations have implemented or are considering methods to reduce the environmental impacts of waste disposal.

The country with the greatest experience using large-scale digestion facilities has been Denmark, where 18 large centralized plants are now in operation. In many cases these facilities

A centralized Danish digester processing manure, organic industrial residue, and biowaste

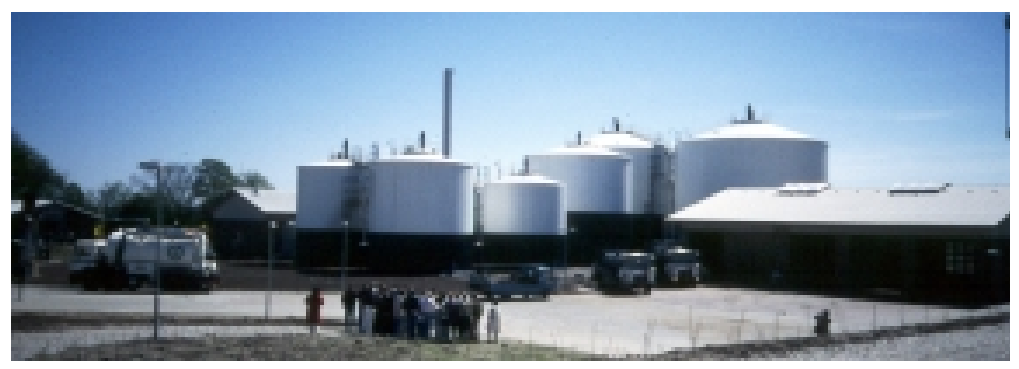

codigest manure, clean organic industrial wastes, and sourceseparated municipal solid waste (MSW).

Denmark's commitment to AD increased with an energy initiative $^{6}$ that will double biogas production by the year 2000, and triple it by the year 2005. One of

the key policy tools used to encourage technology deployment is "green pricing," i.e., allowing manufacturers of biogas-generated electricity to sell their product at a premium. Interestingly, the sales of cogenerated hot water to specially-built district heating systems is becoming an important source of revenue for project developers.

\footnotetext{
${ }^{6}$ Danish Ministry of Energy and Environment (1996). Energy 21; The Danish Government's Action Plan for Energy 1996. Copenhagen, Denmark.
} 
The use of the AD process for treating industrial wastewaters has grown tremendously during the past decade. Worldwide, more than 1,000 vendor-supplied systems now operate or are under construction. It is estimated that European plants comprise $44 \%$ of the installed base. Only $14 \%$ of the systems are located in North America. A considerable number of the systems are located in South America, primarily Brazil, where they are used to treat the vinasse coproduct from sugar cane-based ethanol production. ${ }^{7}$

\section{A digester treating dilute wastewater at a fuel ethanol production plant in Brazil (photo credit: Paques BV)}

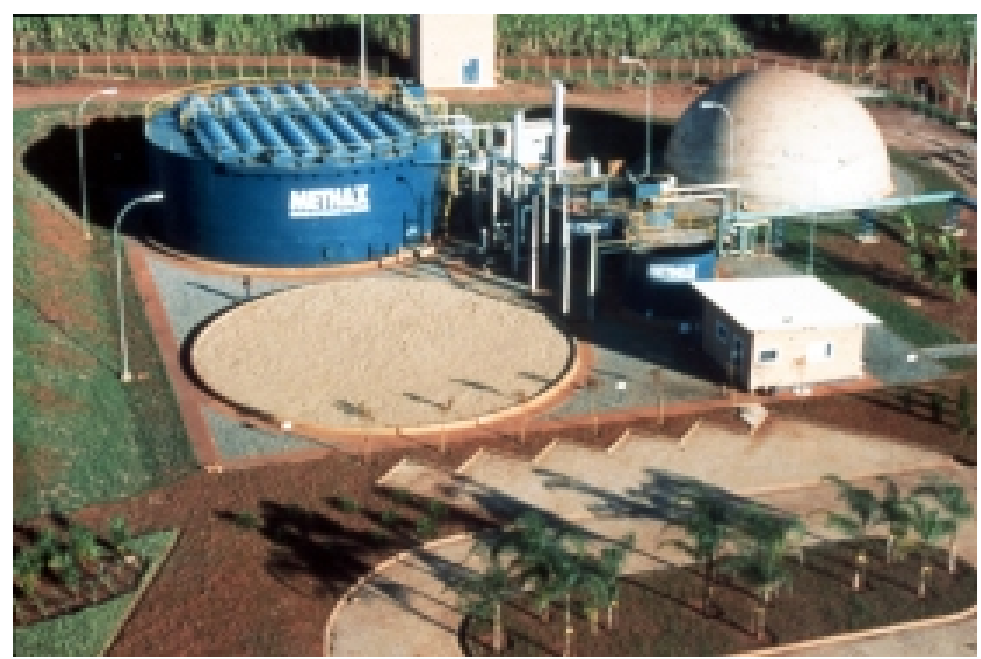

More than 35 example industries that use digesters have been identified, including processors of chemicals, fiber, food, meat, milk, and pharmaceuticals. Many use AD as a pretreatment step that lowers sludge disposal costs, controls odors, and reduces the costs of final treatment at a municipal wastewater treatment facility. From the perspective of the municipal facility, pretreatment effectively expands treatment capacity.

This MSW digester has operated continuously since 1988 (photo credit: Krijn Braber, NOVEM)

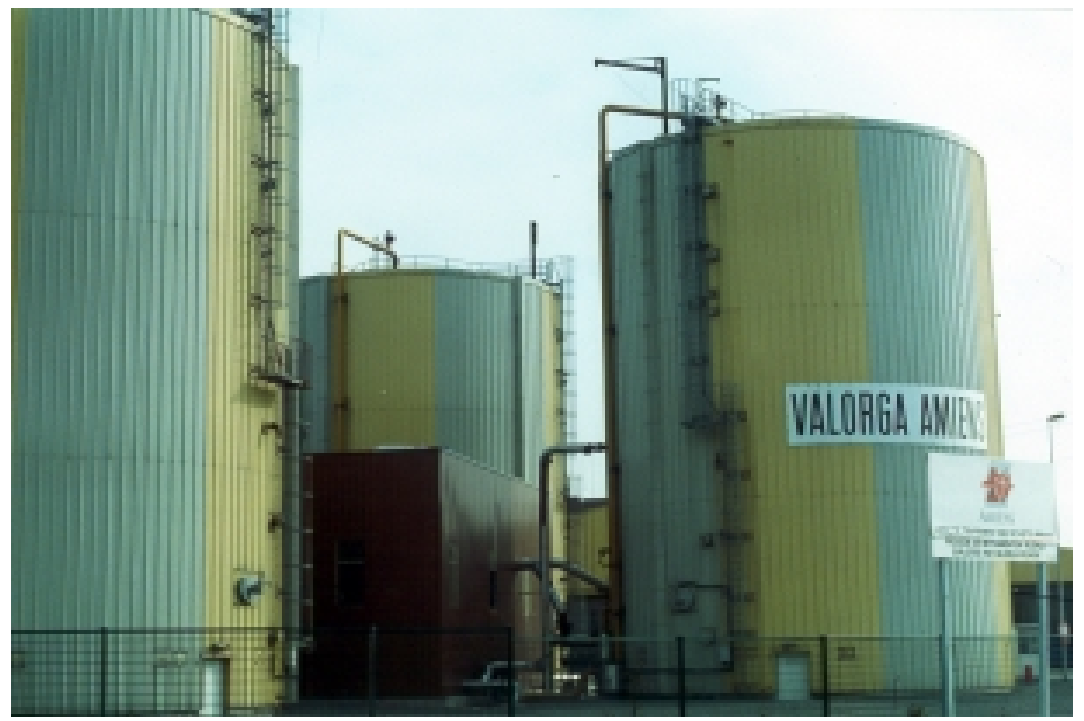

Although the first digester to use MSW as a feedstock operated in the United States from 1939-1974, it is receiving renewed interest. MSW processing facilities have made significant progress towards commercial use in recent years, with several in operation for more than 15 years. A number of types of systems have been developed; each has its own special benefits.

Processes such as AD and composting offer the only

biological route for recycling matter and nutrients from the organic fraction of MSW. Composting is an energy-consuming process, requiring $50-75 \mathrm{kWh}$ of electricity per ton of

\footnotetext{
${ }^{7}$ Lettinga, G.; Van Haandel, A. (1992). "Anaerobic Digestion for Energy Production and Environmental Protection." Chapter 19 in Renewable Energy: Sources for Fuels and Electricity. Covelo, CA: Island Press. pp. 817-839.
} 
MSW input. Composting technology for MSW is commercially available and in use, but its further application is limited mainly by environmental aspects and process economics. AD is a net energy-producing process, with around 75-150 kWh of electricity created per ton of MSW input. MSW digestion technology is now being demonstrated and fully commercialized.

MSW digestion poses many technical problems, including an increase in HRT. High-solid digestion (HSD) systems have been developed with the potential to improve the economic performance of MSW systems by reducing digester volume and the parasitic energy required for the $\mathrm{AD}$ process. Several alternative HSD designs have been developed that operate with total solids (TS) concentrations ${ }^{8}$ greater than $30 \% .^{9}$ These designs employ either external or internal mixing, using biogas or mechanical stirrers. In general, all HSD systems have equivalent performance.

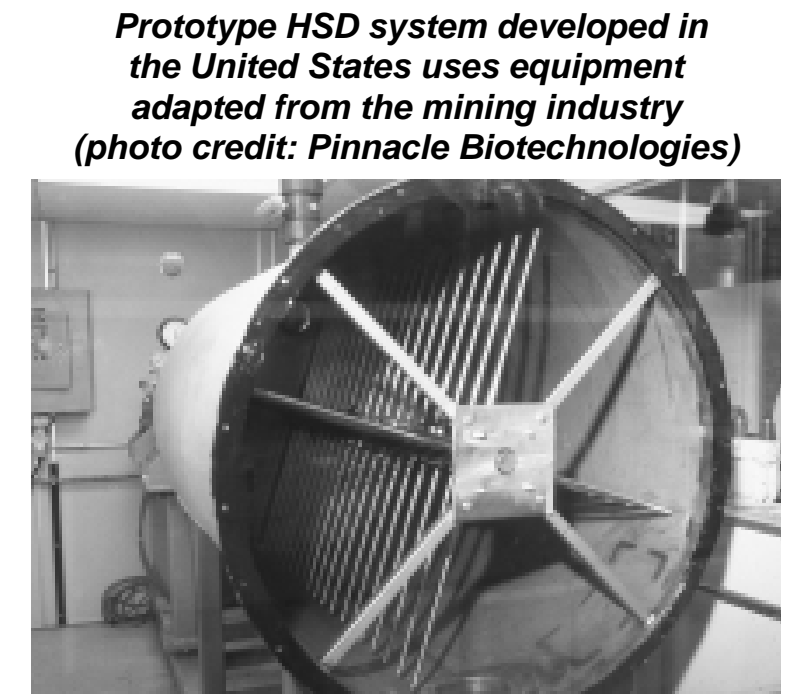

\subsection{Farm-Based Anaerobic Digestion Practices in the United States}

Although some effort has focused on the AD of caged layer poultry manures, the manures from dairy and swine operations tend to be more suitable for farm-based energy conversion. This is because dairy and swine manure management systems are often liquid or slurry based, which simplifies the necessary manure movement. Also, poultry manures contain a higher concentration of fine solids that can quickly fall out of suspension unless continuously agitated. If not kept in suspension, these solids can quickly reduce reactor volume and its ability to produce biogas.

The nation's first farm-based digester was initiated as a result of a now familiar problem--urban encroachment. The McCabe Farm built most of its hog production facilities between 1951-1953 on a rural site outside of the town of Mt. Pleasant, Iowa. By 1970, the town had expanded to the farm's border, and the McCabe family had to develop an odor-free system of managing swine manure. Initially, the McCabes converted their anaerobic lagoon into an aerobic system by adding an aerator. However, the buildup of organic matter over the winter took 6-8 weeks to stabilize in the spring, during which time a significant odor problem developed. Chemicals were added to the aerobic lagoon in early spring one year, and it helped control odors but did not eliminate them.

\footnotetext{
${ }^{8}$ n.b., TS concentration is the fraction of total feedstock weight which is a solid material.

${ }^{9}$ Rivard, C. (1995). “Anaerobic Digestion of Municipal Solid Waste.” Second Biomass Conference of the Americas; August 21-24. Portland Oregon. Golden, CO: National Renewable Energy Laboratory, pp. 801-808.
} 
Access port to first U.S. farm digester; the system was installed for odor control

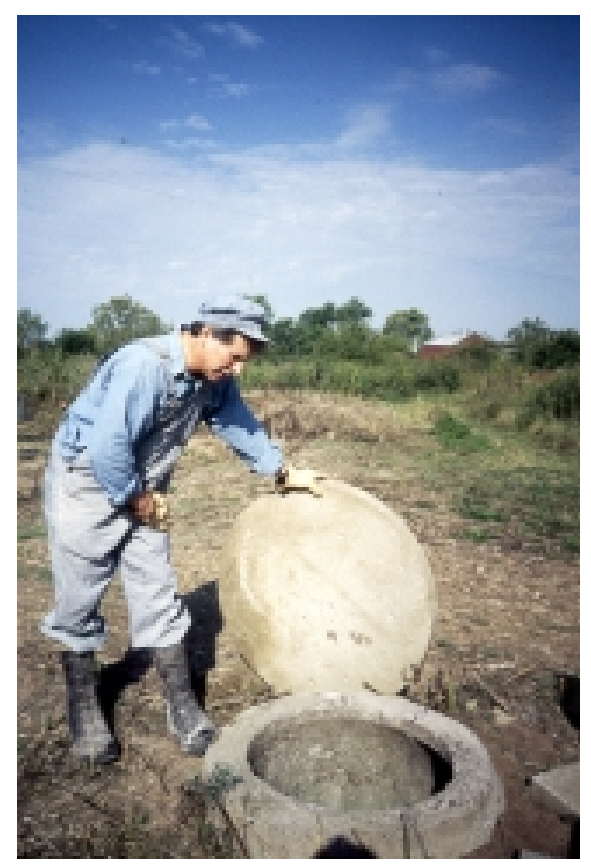

A new system was needed that would deodorize the manure all year and allow it to be spread according to the farm's schedule during good weather. With the assistance of the County Extension Service and others, Harold "Wiz" McCabe found what appeared to be a satisfactory solution in a theoretical article describing the AD of swine manure. The process promised to provide a gas that could be easily disposed of and would produce a stabilized sludge that could be spread anywhere. "Wiz" was an innovator and master mechanic, and he took a crash course in the design and construction of a complete-mix anaerobic digester. It took 2 years to locate and install the reactor, fabricate heat exchangers from old dairy equipment, convert an old dairy 10-horsepower upright boiler to operate on both biogas and propane, install the necessary control and safety equipment, and put all the pieces together. In early May 1972, the digester was seeded with 6,000 gallons (gal) of sludge from the town's municipal waste digester and two hours of manure flow from the swine facility. Over the next few days, digester seeding continued on a planned schedule. On 10 May, the fifth day after digester inoculation, excess biogas tripped a relief valve and the first farm-based digester in the United States came to life.

During the energy crises of the mid- and late 1970s, the search for alternative energy resources led to investigation of small- and medium-scale anaerobic digesters developed in India and China to determine whether these technologies were directly transferable to farms in the United States. Unfortunately, although these technologies are useful in providing fuel for cooking and lighting in developing economies, most are much too small to be useful to most American farmers. For example, the typical small-scale digester daily produces about the same amount of energy as contained in 1 gal of propane. ${ }^{10}$

The greater energy requirements of the larger American livestock operations led to the design and installation of several demonstration projects that transferred state-of-the-art sewage treatment plant technology to the farm. Although complete-mix digesters can operate in the thermophilic temperature range, the demonstration projects at facilities such as the Washington State Dairy Farm in Monroe ${ }^{11}$ operated only in the mesophilic temperature range. At the Monroe project the digester was sized for the manure volume produced by a milking herd of 180-200 Holstein cows.

Although these first-generation complete-mix digesters generally produced biogas at the target design rate, they suffered from high capital costs and significant O\&M requirements. In practical

\footnotetext{
${ }^{10}$ Volunteers in Technical Assistance (1979). Design and Construction of a Three-Meter Anaerobic Digester. Mt Ranier, MD: VITA.

11 Coppinger, E. et al. (1980). "Economics and Operational Experience of a Full-Scale Anaerobic Dairy Manure Digester." Chapter 6 in Biogas and Alcohol Fuels Production. Emmaus, PA: The JG Press.
} 
application on the farm, solids settling, scum formation, and grit removal often presented major problems.

Today's complete-mix digesters can handle manures with TS concentrations of 3\%-10\%, and generally can handle substantial manure volumes. The reactor is a large, vertical, poured concrete or steel circular container. The manure is collected in a mixing pit by either a gravity-flow or pump system. If needed, the TS concentration can be diluted, and the manure can be preheated before it is introduced to the digester reactor. The manure is deliberately mixed within the digester reactor. The mixing process creates a homogeneous substrate that prevents the formation of a surface crust and keeps solids in suspension. Mixing and heating improve digester efficiency. Complete-mix digesters operate at either the mesophilic or thermophilic temperatures range. with a HRT as brief as 10-20 days.

A fixed cover is placed over the complete-mix digester to maintain anaerobic conditions and to trap the methane-rich biogas that is produced. The methane is removed from the digester, processed, and transported to the site of end-use application. The most common application for methane produced by the digestion A modern dairy farm
complete-mix digester that
also recovers valuable fiber

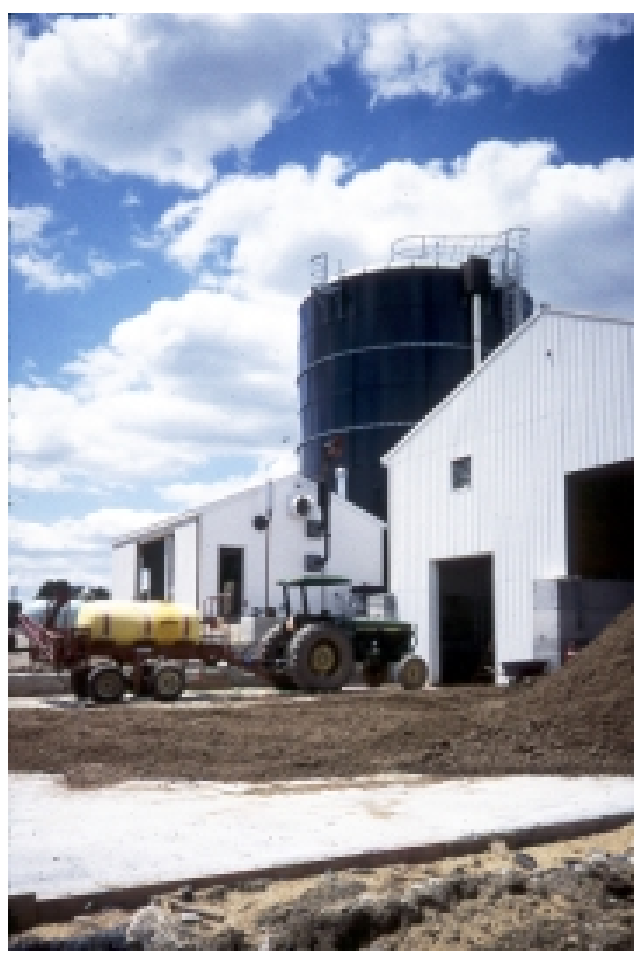
process is electricity generation using a modified internal combustion engine. Both the digester and the mixing pit are heated with waste heat from the engine cooling system. Complete-mix digester volumes range considerably from about 3,500-70,000 cubic feet $\left(\mathrm{ft}^{3}\right)$. This represents daily capacities of about 25,000-500,000 gal of manure/digester. Larger volumes are usually handled by multiple digesters.

By the late-1970s researchers at Cornell University ${ }^{12}$ were able to reduce the capital costs and the operational complexities associated with the early complete-mix digesters by using a simple extension of Asian AD technology.

These "plug-flow" digesters were adopted with some success in the cooler climate of the Northeast, where dairy farms primarily use scraping systems for manure removal. The 1979 project at the Mason Dixon Dairy Farms in Gettysburg, Pennsylvania, was the first plug-flow digester operated on a commercial farm. At the Mason Dixon project, the plug-flow digester was originally sized for a manure volume produced by a milking herd of 600 Holstein cows.

\footnotetext{
12 Jewell , W. et al. (1979) "Low Cost Methane Generation on Small Farms." Third Annual Symposium on Biomass Energy Systems. Golden, CO: Solar Energy Research Institute.
} 
The plug-flow digester, easily recognizable by its roughly 1:5 dimensions, is used only on dairy farms

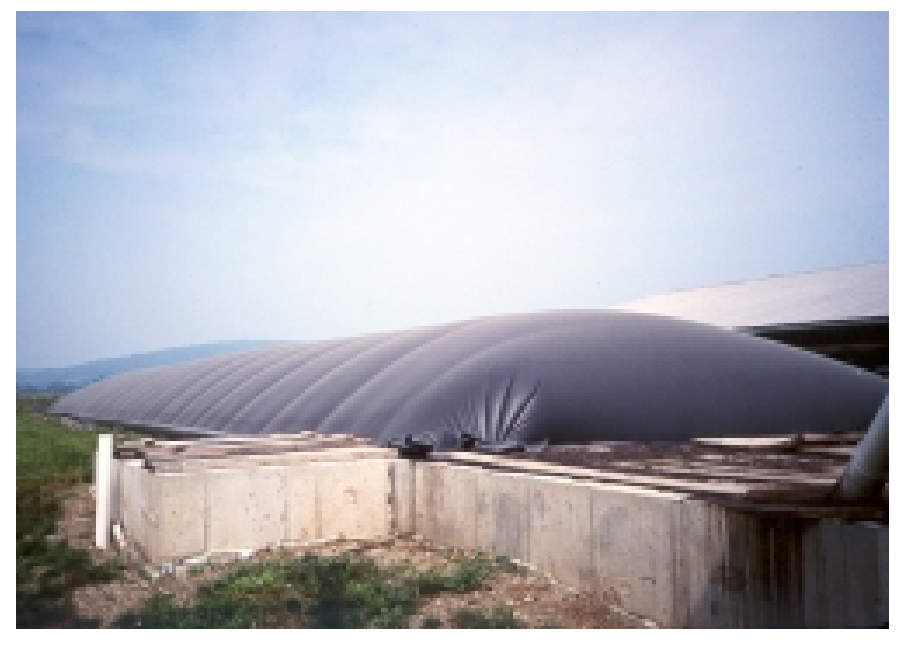

The basic plug-flow digester design is a long linear trough, often built below ground level, with an air-tight expandable cover. Manure is collected daily and added to one end of the trough. Each day a new "plug" of manure is added, slowly pushing the other manure down the trough. The size of the plug-flow system is determined by the size of the daily "plug." As the manure progresses through the trough, it decomposes and produces methane that is trapped in the expandable cover. To protect the flexible cover and maintain optimal temperatures, some plug-flow digesters are enclosed in simple greenhouses or insulated with a fiberglass blanket. Plug-flow digesters usually operate at the mesophilic temperature range, with a HRT from 20-30 days. An often vital component of a plug-flow digester is the mixing pit, which allows the TS concentration of the manure to be adjusted to a range of $11 \%-13 \%$ by dilution with water. Many systems use a mixing pit with a capacity roughly equal to 1 day's manure output to store manure before adding it to the digester.

The complete-mix and plug-flow digestion technologies are not suited for use on farms that use hydraulic flushing systems to remove manure and anaerobic lagoons to treat waste. Hydraulic flushing substantially dilutes the manure, with TS concentrations often far less than $3 \%$. An anaerobic lagoon is a popular method used to treat and store manure. A properly designed and operated anaerobic lagoon system, in which the HRT exceeds 60 days, may produce significant quantities of methane.

In the early 1980s, the concept of using a floating cover to collect biogas as it escapes from the surface of an anaerobic lagoon was transferred from industry to the farm. The first successful floating cover that recovered biogas from an anaerobic lagoon operating in the psychrophilic range was sponsored by the California Energy Commission at the Royal Farm operation in Tulare, California. ${ }^{13}$ The Royal Farm's digester used the manure from a 1,600-sow farrow-to-finish farm.

\section{A partial cover installed on one cell of the three-cell lagoon system at Royal Farm (photo credit: California Energy Commission)}

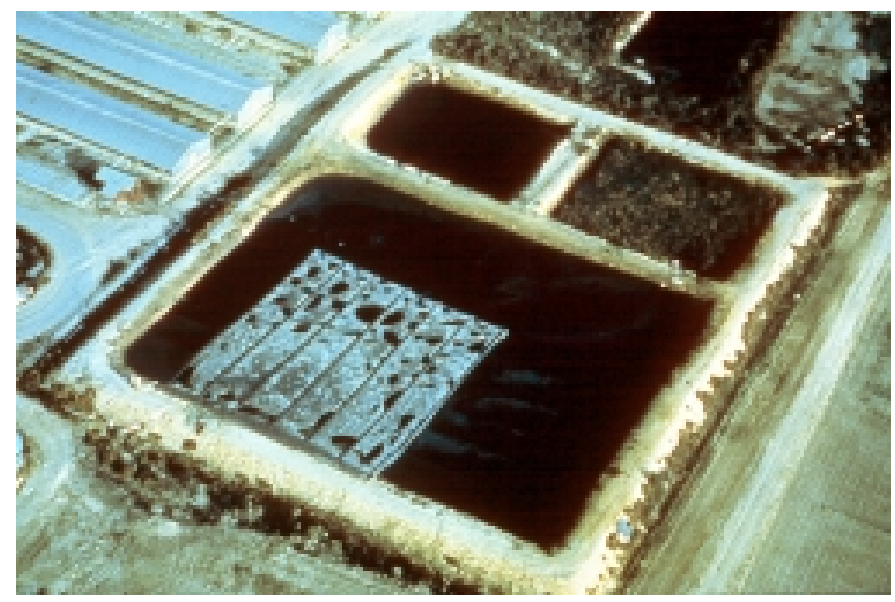

13 Chandler, J. et al. (1983) “A Low-Cost 75-kW Covered Lagoon Biogas System.” Paper at Energy from Biomass and Wastes VII, Lake Buena Vista, FL. 
The North Carolina Energy Division and North Carolina State University constructed the first full-scale covered anaerobic lagoon digester on the east coast at the Randleigh Dairy in $1988 .{ }^{14}$ The digester processed the manure from 150 dairy cows. The project used funds provided by the Southeast Regional Biomass Energy Program (RBEP), the North Carolina Agricultural Research Service, and the North Carolina Dairy Foundation. The project objective was to educate dairy producers through practical demonstration and outreach about the merits of a low-cost and easily

Covered lagoon system at Randleigh Dairy (photo credit: RCM Digesters)

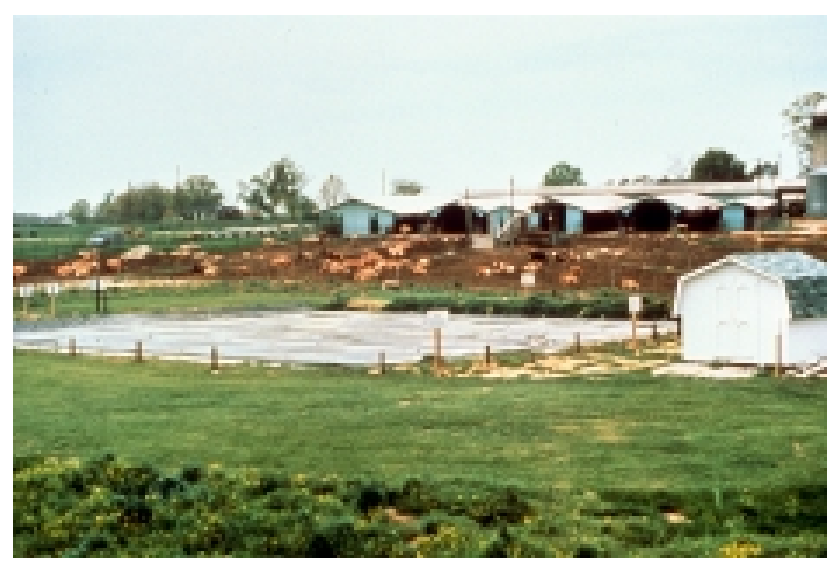
maintained digester suitable for use on farms using hydraulic flush manure management systems. The project provided information about the amount of biogas that can be recovered, along with cost information from which the economic merit of the technology can be evaluated.

The methane produced in an anaerobic lagoon is captured by placing a floating, impermeable cover over the lagoon. The cover is constructed of an industrial fabric that rests on solid floats laid on the surface of the lagoon. The cover can be placed over the

Once the cover is installed, the methane produced under the covered area of the lagoon is trapped. The biogas is harvested using with a collection manifold, such as a long perforated pipe, that is placed under the cover along the sealed edge of the lagoon. Methane is removed by the pull of a slight vacuum on the collection manifold (by connecting a suction blower to the end of the pipe) that draws the collected biogas out from under the cover and on to the end-use application.

The cover is held in position with ropes and anchored by a concrete footing along the edge of the lagoon. Where the cover attaches to the edge of the lagoon, an air-tight seal is constructed by placing a sheet of the cover material over the lagoon bank and down several feet into the lagoon, and clamping the cover (with the footing) onto the sealed bank. Seals are formed on the remaining edges with a weighted curtain of material that hangs vertically from the edge of the floating cover into the lagoon.

\footnotetext{
${ }^{14}$ Safley, L.M.; Lusk, P. (1990). Low Temperature Anaerobic Digester. Raleigh, NC: Department of Commerce, Energy Division.
} 
The covered lagoon digester has several merits. First, it has good potential for widespread adoption in the United States, especially in the southeast and southwest regions, because many dairy and swine facilities use hydraulic flushing to collect manure and anaerobic lagoons to treat waste. Second, covered lagoon digester O\&M is simple and straightforward compared to complete-mix and plug-flow digesters. Third, the capital costs for this type of digester can be less than those required for the complete-mix and plug-flow types of conventional digesters.

Covering an anaerobic lagoon and harvesting

Hydraulic flushing creates a manure too dilute to be used in conventional reactors such as complete-mix or plug-flow digesters

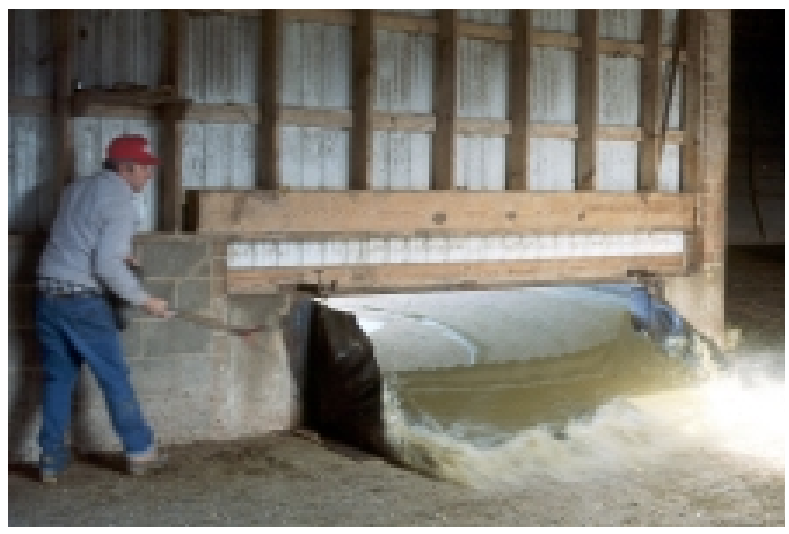

the biogas can be a simplified technology; however, the approach raises at least three significant concerns. A key issue is that digestion rate is dependent on temperature; therefore, biogas production varies seasonally if the lagoon is not externally heated. This means that methane production is greatest in the warm, summer months and lowest during the cooler, winter months. At the Randleigh Dairy, daily biogas production during the summer averaged $35 \%$ more than during the winter. This may make end-use applications more problematic than they are with conventional digesters, which have less significant seasonal variations in methane production. A second concern is that it can take an anaerobic lagoon as long as 1-2 years to achieve its "steadystate" biogas production potential. It is best to start a project of this type in late spring or early summer to take advantage of warm weather. Digesters that are started during cool months are subject to upset from overfeeding. Moreover, any anaerobic lagoon (covered or not) is impractical in areas with a high water table because of the potential for groundwater contamination. Lagoons built into highly permeable soils must be adequately lined to prevent groundwater contamination.

The complete-mix, plug-flow for dairy, and the covered anaerobic lagoon are the only ones now recognized ${ }^{15}$ by the USDA's Natural Resource Conservation Service (NRCS) in the form of "National Guidance provided to States." Other types of AD systems may have the technical and economic potential to process animal manures.

\footnotetext{
${ }^{15}$ NRCS (1996). Covered Anaerobic Lagoon (Code Number 360), Plug-Flow Digester (Code Number 363i) and Complete-Mix Digester (Code Number 364i). Washington, DC: U.S. Department of Agriculture.
} 
The reactor for this slurry system is a poured concrete silo, and the building on the left houses the engine used for producing electricity

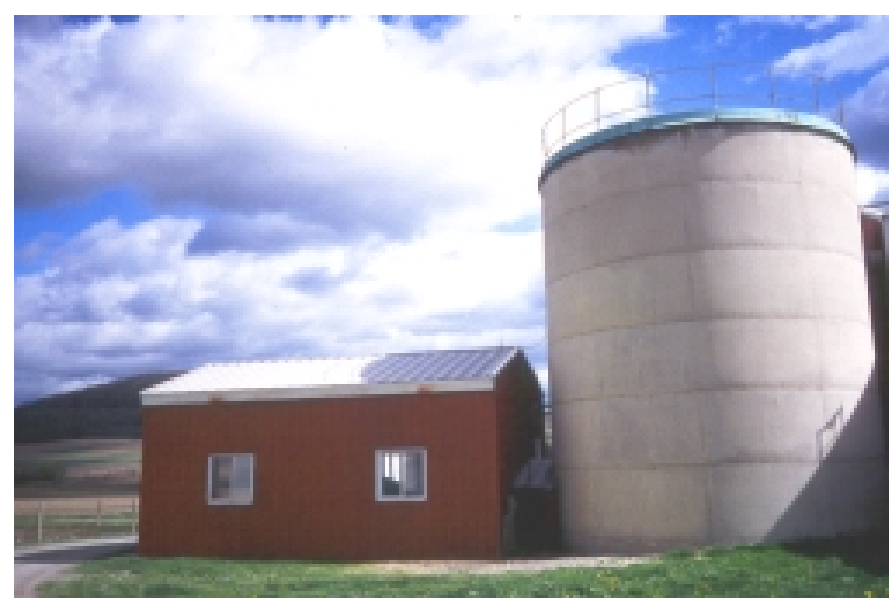

One digester type that might be considered by some to be a variant of the plug-flow digester is referenced in this report as a slurry-based system. Unlike plug-flow systems that are used only on dairy farms and that require manure TS concentrations of $11-13 \%$, slurry-based digestion systems can operate with much lower solids concentrations and can be used to treat a variety of animal manures. Slurry systems require no mechanical mixing and are often found as silo-type reactors or in a "loop" or horseshoe configuration. Several operators believe the slurry design can enable greater convective currents in the digester, thereby helping to avoid the solids crusting problem commonly associated with the plug-flow design when TS concentrations fall below design parameters.

\subsection{Energy and Anaerobic Digestion}

The theoretical methane yield can be shown to be $5.6 \mathrm{ft}^{3} /$ pound (lb) of chemical oxygen demand converted, but the exact recoverable yield depends on a number of environmental conditions. The ultimate yield of biogas depends on the composition and biodegradability of the organic feedstock, but its production rate will depend on the population of microorganisms, their growth conditions, and fermentation temperature.

Methane produced by the AD process is quite similar to "natural" gas that is extracted from the wellhead. However, natural gas contains a variety of hydrocarbons other than methane, such as ethane, propane, and butane. As a result, natural gas will always have a higher calorific value than pure methane. Depending on the digestion process, the methane content of is biogas generally between $55 \%-80 \%$. The remaining composition is primarily carbon dioxide, with trace quantities (0-15,000 ppm) of corrosive hydrogen sulfide and water.

According to Meynell, ${ }^{16}$ the average expected energy content of pure methane is 896-1069 $\mathrm{Btu} / \mathrm{ft}^{3}$; natural gas has an energy content about $10 \%$ higher because of added gas liquids like butane. However, the particular characteristics of methane, the simplest of the hydrocarbons, make it an excellent fuel for certain uses. ${ }^{17}$ With some equipment modifications to account for its lower energy content and other constituent components, biogas can be used in all energyconsuming applications designed for natural gas.

\footnotetext{
${ }^{16}$ Meynell, P-J. (1976). Methane: Planning a Digester. New York: Schocken Books. pp. 30-31.

17 Ross, C. et al. (1996). Handbook on Biogas Utilization. $2^{\text {nd }}$ Edition. Muscle Shoals, AL: Southeastern Regional Biomass Energy Program, Tennessee Valley Authority.
} 
Today, it is commonly burned in an internal combustion engine to generate electricity. Practical experience with small-scale internal combustion engines with a rated capacity of less than 200-

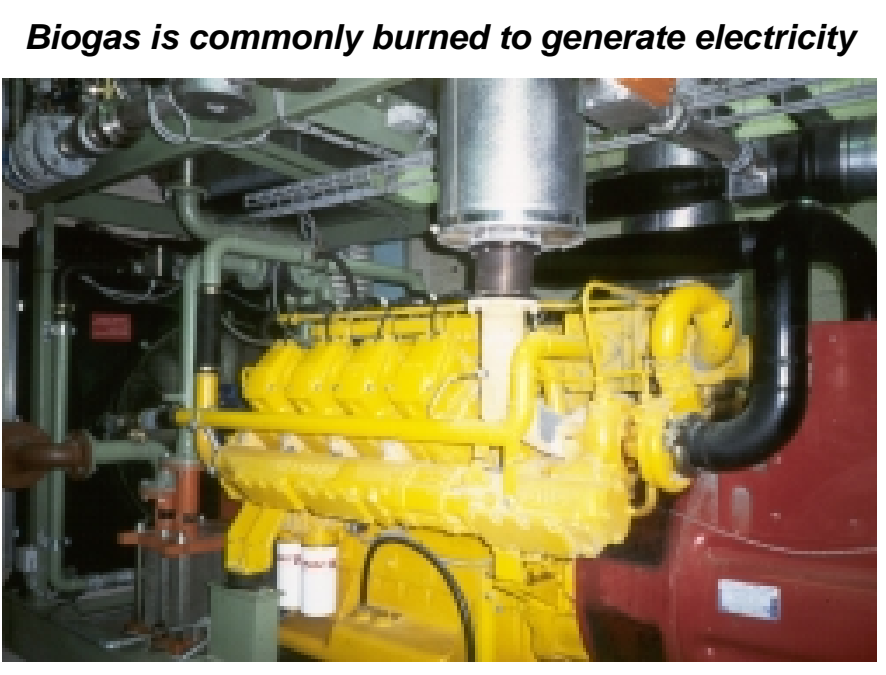

$\mathrm{kW}$ indicate an electrical conversion efficiency of less than $25 \% .{ }^{18}$ Larger engines can have a greater conversion efficiency. One engine supplier claims to have an engine with an electrical conversion efficiency that averages $38 \%$ for engines in the $600-1000 \mathrm{~kW}$ range. ${ }^{19}$

When biogas is used to produce electricity, there is the added potential for harvesting hot water and steam from the engine's exhaust and cooling systems. Combining hot water and steam recovery with electricity generation may provide an overall conversion efficiency of $80 \%$ or more. Biogas is also burned in boilers to produce hot water and steam used for heating and sanitary washing.

While operating at a technology level requiring specially trained maintenance personnel, a promising near-term application for biogas-fueled electricity generation is the use of gas turbines. For larger-scale systems, combined cycle power stations consist of gas turbines, steam turbines, and waste heat recovery boilers, all working together to produce electricity. Modern gas turbine plants are small, environmentally friendly, and visually unobtrusive. Units as small as 200-kW are available but their electrical efficiency is quite low, around 16-18\%. ${ }^{20}$ Only at scales of greater than $800-\mathrm{kW}$ does the heat rate equal or surpass an engine-based system. However, the use

\section{Although this utility-scale system is used for district heating by dozens of homes, making hot water in a boiler is the simplest end-use of biogas}

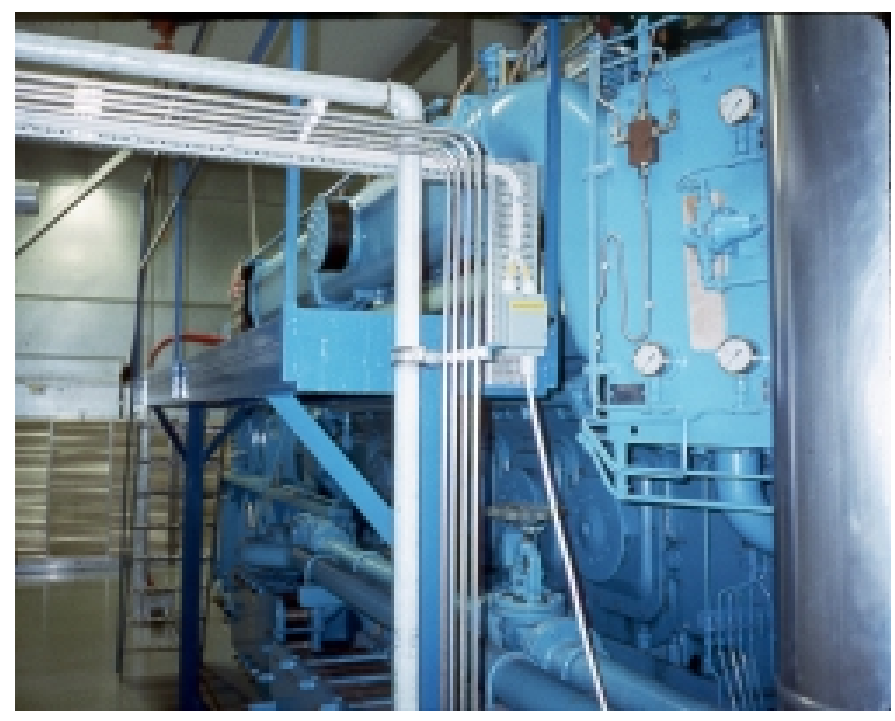
of a gas turbine allows a greater fraction of the waste heat to be recovered as potentially more valuable steam. Overall gas turbine efficiency can be greater than $70 \%$.

\footnotetext{
18 Moser, M. (15 April 1997). Personal communication. RCM Digesters, Inc., Berkeley, CA.

${ }^{19}$ Jenbacher Energiesysteme (1998). Information available at http://mirror.us.netwing.at/jenbacher/60hz.htm.

${ }^{20}$ Gas Turbine Performance (1997). Information available at http://www.gas-turbines.com/specs/power.htm.
} 


\section{A compact unit that scrubs and compresses biogas for use an alternative motor fuel}

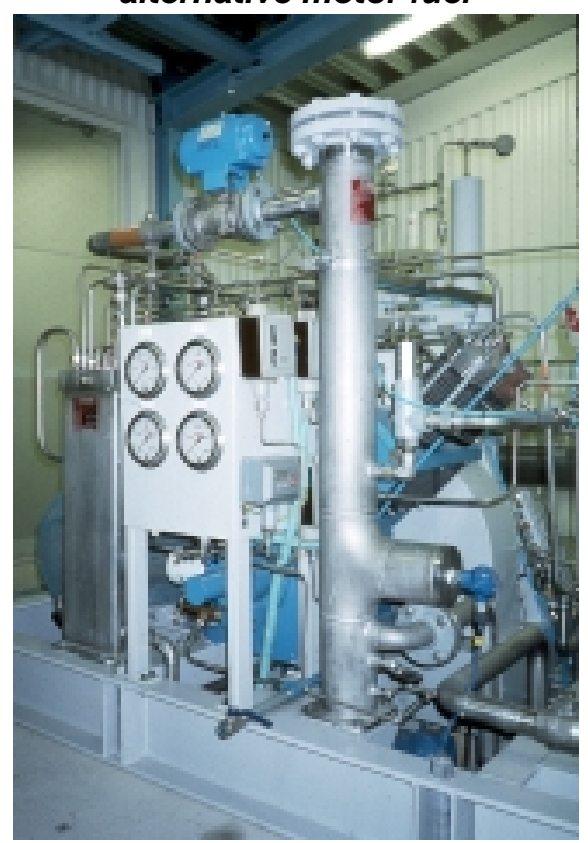

Biogas is also successfully compressed for use as an alternative transportation fuel in light- and heavy-duty vehicles. To obtain usable methane, the biogas is scrubbed of its carbon dioxide, hydrogen sulfide, and water. After scrubbing, the technique of fueling with biogas is basically the same as that used for compressed natural gas $(\mathrm{CNG})$ vehicles. Although only a few thousand vehicles are using biogas, it is estimated that worldwide around one million vehicles are now using CNG as a transportation fuel.

The change to $\mathrm{CNG}$ operation means that a vehicle is converted or that a new one is specially built. Vehicles can operate in three different modes: as a dedicated CNG; as a bi-fuel on either gas or gasoline; or as a simultaneous dualfuel on gas and diesel fuel. The CNG is stored in a number of tank cylinders made of steel or fiberglass that are filled with gas to a high pressure. The normal number of tank cylinders will provide enough capacity to cover $150-175$ miles. Fleet vehicles that are parked overnight, such as buses, are fueled slowly for 5-8 hours. Quick filling takes about 2-5 minutes, and is used for vehicles in constant use such as service vans. Because methane burns very cleanly, many fleet operators have reported savings of $40 \%-50 \%$ in vehicle maintenance costs.

In many countries, biogas is viewed as an environmentally attractive alternative to diesel and gasoline for operating buses and other local transport vehicles. The level of sound generated by methanepowered engines is generally lower than that generated by diesel engines, which is a positive aspect, particularly in an urban environment. Exhaust fume emissions are considerably lower than the emissions from diesel engines, and the emission of nitrogen oxides is very low.

\section{This city of 100,000 fuels its entire fleet of buses and other heavy vehicles with biogas from its centralized digester}

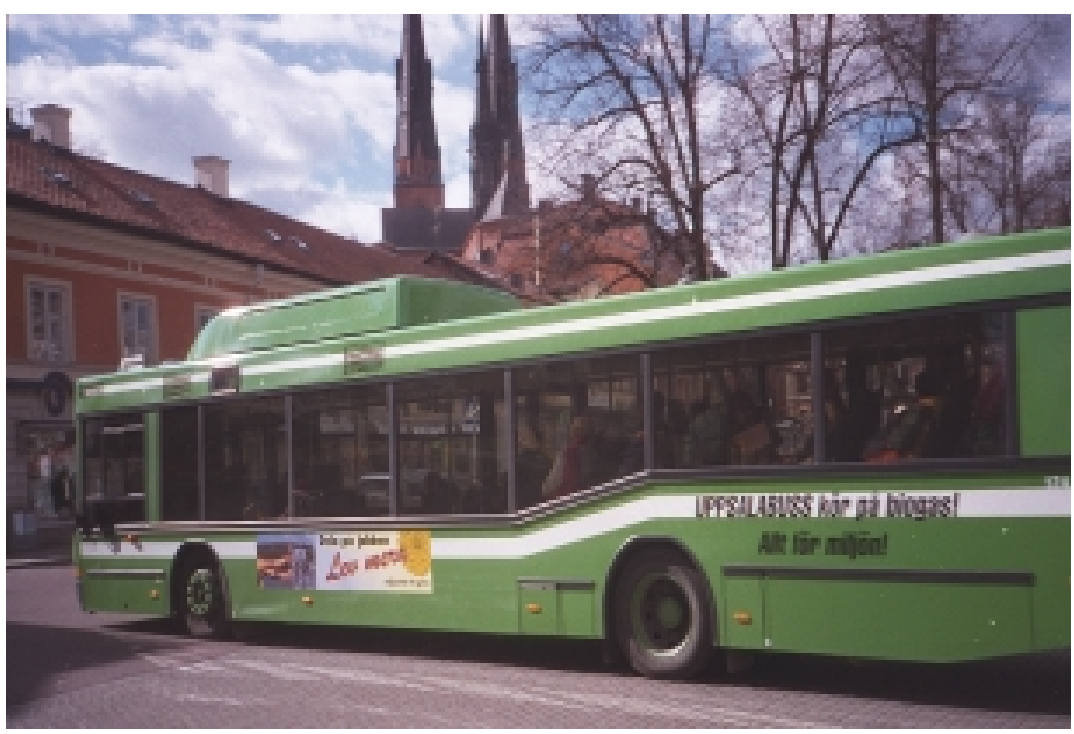




\subsection{Environment and Anaerobic Digestion}

Growth and concentration of the livestock industry in the United States create opportunities for the proper disposal of the large quantities of manures generated at dairy, swine, and poultry farms. The potential pollutants from decomposing livestock manures are BOD, pathogens, nutrients, methane, and ammonia emissions. The major pollution problems associated with these wastes are surface and groundwater contamination and surface air pollution caused by odors, dust, and ammonia. There is also concern about the contribution of methane emissions to global climate change. Consequently, manure management systems that enable prevent pollution prevention and produce energy are becoming increasingly attractive.

Methods of controlling agricultural non-point pollution sources are not as developed as those for point sources. Solutions to non-point problems involve land-use planning and practices that are largely the responsibility of state and local governments. Most federal efforts to control agricultural non-point sources have emphasized a voluntary, non-regulatory approach based on the implementation of best management practices (BMPs) instead of regulations. In developing BMPs, states often take economic, institutional, and technical factors into consideration.

Section 319 of the federal Clean Water Act created a program to control non-point sources of pollution and to protect groundwater. Each state is required to submit an assessment of state waters that fall below water quality standards because of non-point source pollution. Each state is also required to develop a management program for controlling non-point source pollution. Most agricultural activities have been classified as non-point sources of water pollution. Livestock nonpoint sources of water pollution include range and pastureland, feeding and watering sites, confinement facilities, and manure disposal areas. These wastes are widely dispersed and are more difficult to regulate than effluents from point sources such as sewers and pipes. Including point sources, agriculture is now alleged to be the leading source of water pollution in the country. ${ }^{21}$ Many livestock producers believe that these figures are not accurate and are biased upward because only those waters known to have water quality problems are sampled.

According to a U.S. Senate study, ${ }^{22}$ there are no national standards for dealing with animal manures. Although the units were not detailed, the study also reported that the amount of animal manure produced in the United States is 130 times greater than the amount of human waste. Using one example, a single 50,000-acre hog farm being built in Utah could produce more residues than the city of Los Angeles. "As animals become increasingly concentrated... and on larger operations, there is not always enough crop land to use all of the manure as fertilizer. These

21 Weinberg, R. (1991). “EPA Programs Addressing Animal Waste Management.” Proceedings of a National Workshop on Livestock, Poultry \& Aquaculture Waste Management. Niles, MI: American Society of Agricultural Engineers.

${ }^{22}$ U.S. Senate Committee on Agriculture, Nutrition, \& Forestry (1997). Animal Waste Pollution in America: Environmental Risks of Livestock \& Poultry Production. Report compiled by the Minority Staff for Senator Tom Harkin (D-IA). Washington, DC. 
increasing concentrations of manure mean that the risk of water pollution from waste spills, runoff from fields, and leakage from storage facilities is also increasing."

The study also indicated the nation's agricultural officials consider $60 \%$ of rivers and streams "impaired", with agricultural runoff the largest contributor to that pollution. In 1997 alone, more

\section{Some recent studies indicate that increasing concentrations of farm animals are associated with a wide range of environmental pollutants}

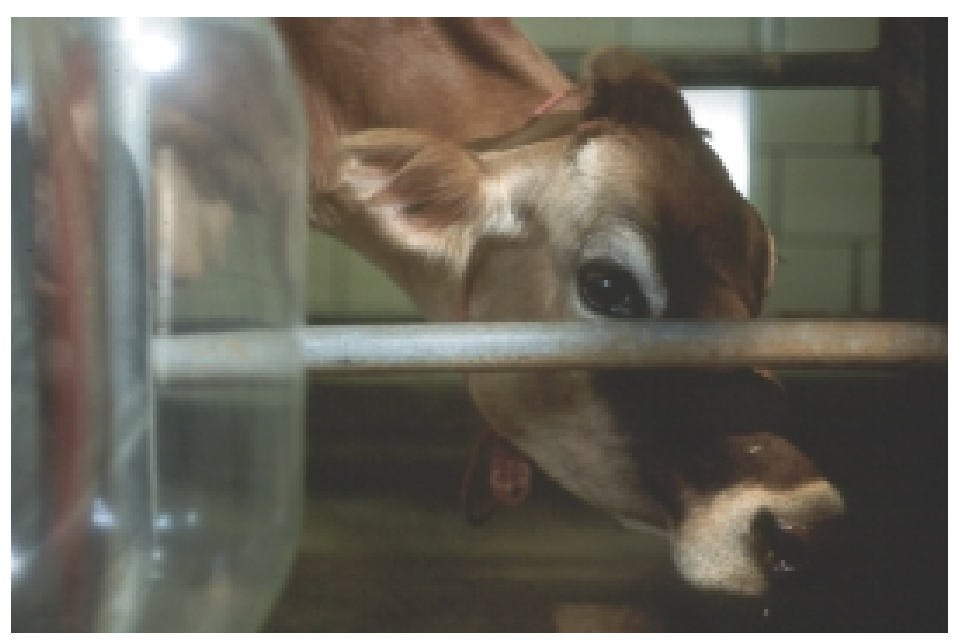

than 40 animal manure spills killed 670,000 fish in Iowa, Minnesota, and Missouri, the study revealed. That was up from 20 spills in 1992. The report also noted that the rise of largescale livestock operations, a growing trend among meat producers, has greatly increased the risk of manure spills, because the large farms produce more manure than can be spread over nearby cropland. For example, over the past 15 years, the number of hog farms nationally has dropped to 157,000 from about 600,000 , but the overall output of hogs has increased.

In March of 1998, the EPA announced plans to begin regulating large livestock farms much like factories and other waste-producing industries, requiring permits and inspections in an unprecedented effort to keep manure out of rivers and streams. The plan would dramatically increase the government's oversight of thousands of the nation's largest farms.

Based on the 1992 Census of Agriculture data, there are 450,000 animal feeding operations with confined (not pasture) feedlots out of a total of 640,000 farms with livestock. ${ }^{23}$ These feedlots primarily include beef, hog, chicken, dairy, and turkey facilities. About 6,600 of these operations fall into the largest category and are referred to as concentrated animal feeding operations (CAFOs). These operations represent approximately 35\% of the total livestock population and are generally concentrated on small land areas. The Clean Water Act currently gives states the authority to regulate CAFOs. A large number come under state regulation, which can be more stringent than that of the federal government. However, in practice only about a quarter of them currently are regulated. ${ }^{24}$

According to the EPA's draft plan, it would apply the Clean Water Act's full authority to an agricultural sector that produces large amounts of waste, yet is exempt from many of the pollution controls that apply to small municipal sewage plants or even septic systems. The EPA's plan

\footnotetext{
${ }^{23}$ U.S. Department of Agriculture, National Agricultural Statistics Service. (1993). Census of Agriculture. The report is available at http://www.nass.usda.gov/census/census92/agrimenu.htm.

${ }^{24}$ U.S. Environmental Protection Agency. (1998). EPA to Better Protect Public Health and the Environment from Animal Feeding Operations. 5 March Press Release, Washington, DC.
} 
includes a long list of proposals that would gradually tighten restrictions on farms over the next 7 years, requiring farms to obtain permits to produce manure, develop plans to properly dispose of it, and undergo inspections to make sure they are following through.

The permits would automatically be necessary for any farm with more than 1,000 "animal units," which the EPA defines as 1,000 cattle, 2,500 swine or 100,000 laying hens. In addition, the regulators could require permits for smaller farms that have a history of pollution or are located in environmentally sensitive areas. Many of the proposals can be implemented under current laws, although a few would require new regulations. The draft strategy sets goals for EPA and the states to fully regulate and issue Clean Water Act permits to the largest CAFOs by 2003 and to fully regulate and permit all other CAFOs and priority facilities in impaired watersheds by 2005 .

Of course, other voices are being raised in this debate about the environmental impact of livestock production and the need for new regulations. Rather than regulations, some call for more effective enforcement of current rules. "If compliance with current regulations is inadequate, then that is what needs to be focused on before any new regulatory schemes are pursued." ${ }^{25}$ Undergirding this discussion is an ongoing debate in several state legislatures and reports in the news media regarding the perceived or real environmental threats of larger and larger operations and, in general, the changing demographics of the livestock industry. "I think that we must keep the current debate on these issues properly divided regarding the credible scientific issues involved with waste management on one hand and separately, the emotional and economic issues of a changing livestock industry.",26

\subsection{Nutrient Utilization and Anaerobic Digestion}

Nearly all animal manures are land applied, which means that some of their nutrient value is returned to the soil for plant growth. However, much of the nutrient value contained in manure can be lost before it is recycled or before the nutrients can be presented in a plant usable form. Susceptibility to problems from high manure nutrient concentrations varies by region, but also because of other factors such as manure nutrient application rates and timing, soil type, climate, tillage and pasture management practices, and conservation practices.

In particular, the various forms of nitrogen-containing compounds (Table 2.1) are associated with a range of issues such as ground and surface water pollution, air pollution, acid rain, and building surface degradation. Phosphorus is not as mobile as some forms of nitrogen and tends to be carried on soil particles that move off the field because of erosion. However, as the phosphorus content in the soil increases, the potential for the element to move off the field in solution is also increased.

\footnotetext{
${ }^{25}$ U.S. House of Representatives, Agriculture Subcommittee on Forestry, Resource Conservation, and Research and the Subcommittee on Livestock, Dairy, and Poultry. (1998). Combest, Pombo Question Need for New Animal Feedlot Regulations, EPA Should First Improve Current Program Management. 13 May 1998 Press Release, Washington, DC.

${ }^{26}$ Supra, Note 25.
} 
TABLE 2.1: Important Nitrogenic Compounds Derived from Agriculture

\begin{tabular}{|l|l|}
\hline $\mathrm{N}_{2}$ & $\begin{array}{l}\text { Molecular nitrogen deriving from denitrification in the earth and surface } \\
\text { water. 78\% of the atmospheric gas is } \mathrm{N}_{2} .\end{array}$ \\
\hline $\mathrm{NO}_{\mathrm{x}}$ & $\begin{array}{l}\text { Nitric oxides comprising } \mathrm{NO}, \mathrm{NO}_{2} \text { and } \mathrm{NO}_{3} \text { (Nitrogen mono-, di- and } \\
\text { trioxide). Formed during incomplete denitrification and during the } \\
\text { combustion of biomass and fossil fuels. }\end{array}$ \\
\hline $\mathrm{NO}_{3}{ }^{-}$ & Nitrate (in water $\mathrm{HNO}_{3}$ : nitric acid). \\
\hline $\mathrm{NO}_{2}^{-}$ & Nitrite (in water $\mathrm{HNO}_{2}:$ nitrous acid). \\
\hline $\mathrm{NH}_{3}$ & $\begin{array}{l}\text { Ammonia (in water } \mathrm{NH}_{4}^{+} \text {: ammonium). Formed during protein \& urea } \\
\text { degradation. }\end{array}$ \\
\hline$\left(\mathrm{NH}_{2}\right)_{2} \mathrm{CO}$ & Urea. Excreted with the urine of mammals (Uric acid in poultry). \\
\hline
\end{tabular}

A problem that may result from applying animal manures is ammonia emissions. For example, more mineral nitrogen than manure is still used as fertilizer in Switzerland and Germany. ${ }^{27}$ Yet, more ammonia emissions are released from manure. An almost equal amount can be lost during manure storage as during its land application. Nitrogen released from manure into the atmosphere returns to ground by rain and wind. In countries such as Denmark with steady winds, nitrogen losses from manure storage in open tanks or lagoons can be as high as $70 \%$. In states such as North Carolina, scientists long ago determined that when livestock manure is discharged into open lagoons, as much as $50 \%$ of the nitrogen is lost as the manure decomposes. Concerns about the atmospheric deposition of nitrogen impacts in the United States are just beginning. ${ }^{28}$

The USDA's NRCS conducted a computer simulation ${ }^{29}$ on nutrients available from livestock manure relative to crop growth requirements. Sixteen livestock population types and 78 harvested crops, including hay crops and pasture, were evaluated. From these estimates, nitrogen and phosphorus availability relative to crop need was calculated for each of the 3,079 counties in the United States.

In a non-legume crops and hay simulation, manure phosphorus availability exceeds the plant uptake and removal potential in 485 counties. This suggests that $16 \%$ of the nation's counties could have excess manure phosphorus availability. As expected, the potential for phosphorus or nitrogen to exceed crop uptake and removal decreases as the breadth of the evaluated land base increases. When a non-legume and legume crops, hay, and pasture simulation is assessed, only 107 counties have manure phosphorus in excess of plant uptake and removal potential. This translates to a nearly $78 \%$ decline in the number of counties from the previous scenario.

\footnotetext{
${ }^{27}$ Wellinger, A. (2 June 1998). Personal communication. NovaEnergie, Ettenhausen, Switzerland.

${ }^{28}$ Leavenworth, S.; Shiffer, J. (5 July 1998). “Airborne Menace.” Raleigh, NC, Raleigh News and Observer.

${ }^{29}$ Lander, C.; Moffit, D.; Alt, K. (1998). Nutrients Available from Livestock Manure Relative to Crop Growth Requirements, Resource Assessment and Strategic Planning Working Paper 98-1. The report is available at http://www.nhq.nrcs.usda.gov/land/pubs/nlweb.html.
} 
The same relationship held true for nitrogen. However, manure nitrogen availability exceeded crop system uptake and removal potential in fewer counties than did phosphorus. In the narrowest simulation, manure nitrogen availability exceeded the uptake and removal potential of non-legume crops and hay in 266 counties. In the broadest simulation, only 35 counties show manure nitrogen availability exceeding the uptake and removal potential of crops, hay, and pasture. This translates to a nearly $87 \%$ decline in the number of counties where nitrogen from manure exceeds uptake and removal potential.

"These simulations reflect potential rather than actual nutrient use because producers may manage manure in ways other than to meet crop nutrient needs. Further, it does not imply that in areas where nutrient availability does not exceed crop nutrient needs that the nutrient resource is being managed properly. Improved nutrient management approaches, alternatives to land application (e.g., production of energy or other products, treatment), and conservation practices will be particularly important to reduce the potential for pollution where nutrient availability from manure exceeds crop needs. The primary value of simulating manure nutrient source and crop uptake and removal capacity by county is as a decision-making tool to help identify potential problem areas, to target resources to them, and to work toward solutions when problems are identified."30

These simulations can not be used to conclude that counties with simulated nitrogen and phosphorus excesses (i.e., above 100\% values) either already experience or will experience water quality impairment from nitrogen or phosphorus moving from farm fields to the broader environment. On the other hand, these simulations can be used to conclude that in counties with simulated nitrogen or phosphorus excesses, some land is susceptible to nutrient overapplication and buildup, and potential release of nutrients to the broader environment if land application of manure is the principal way manures are used.

Mineral fertilizers are often preferred by agriculture. Fresh manure has a tendency to suppress or slow plant growth. Fresh manure applied during active growth may "stick" to the plant or its leaves, reducing respiration and plant growth. The less viscous and the more flowable a manure nutrient source, the more the plant will benefit from manure application. ${ }^{31}$

As livestock production becomes more geographically concentrated, the challenge of using manure effectively, while minimizing adverse environmental effects, becomes more complex. Decision makers will have to grapple with development planning questions; agribusiness and technology developers will have to focus on improved on-farm manure management practices and alternative manure uses; and conservationists will need to dedicate effort to working with producers to reduce potential adverse impacts through the application of conservation systems.

Wise use of the solid and liquid digestate residues from the AD process can have very beneficial environmental effects. The amount, quality, and nature of these products will depend on feedstock quality, digestion method, and the extent of the post-treatment refinement

\footnotetext{
${ }^{30}$ Supra, Note 29.

${ }^{31}$ Mattocks, R. (9 June 1998). Personal communication. Environomics, Riverdale, NY.
} 
processes. Adopting improved manure management practices will be significantly encouraged when the new practice results in reduced operating costs or, ideally, new profit centers.

All manures produce recoverable solid fiber. The exact percentage of recoverable fiber depends on the feedstock. For example, dairy cow manure produces more fiber than pig manure. Fiber is usually recovered by mechanical solids separation equipment such as screw presses or vibrating screens. When digested and composted, this fiber has physical attributes similar to those of a moist peat moss. This product may be used as a soil improver or used as a constituent in potting soils.

\section{Recovering valuable fiber from dairy manure using a screw-press separator}

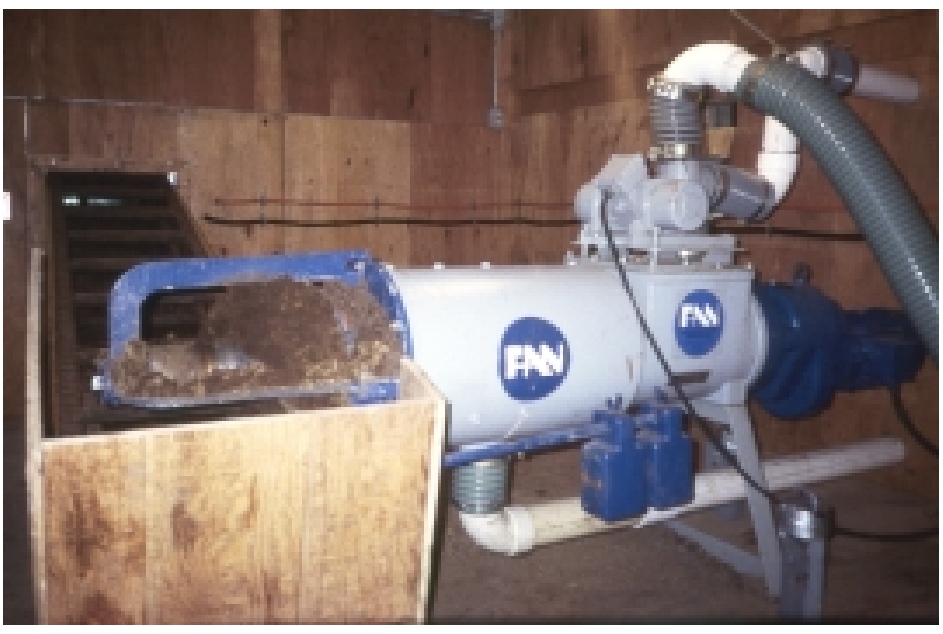

After the fiber is removed, the main digestion product is a liquid organic substance commonly called "filtrate." Filtrate from manures commonly has combined nitrogen, phosphorus, and potassium percentages ranging from $3 \%-4.5 \%$ on a dry matter basis and can be spread

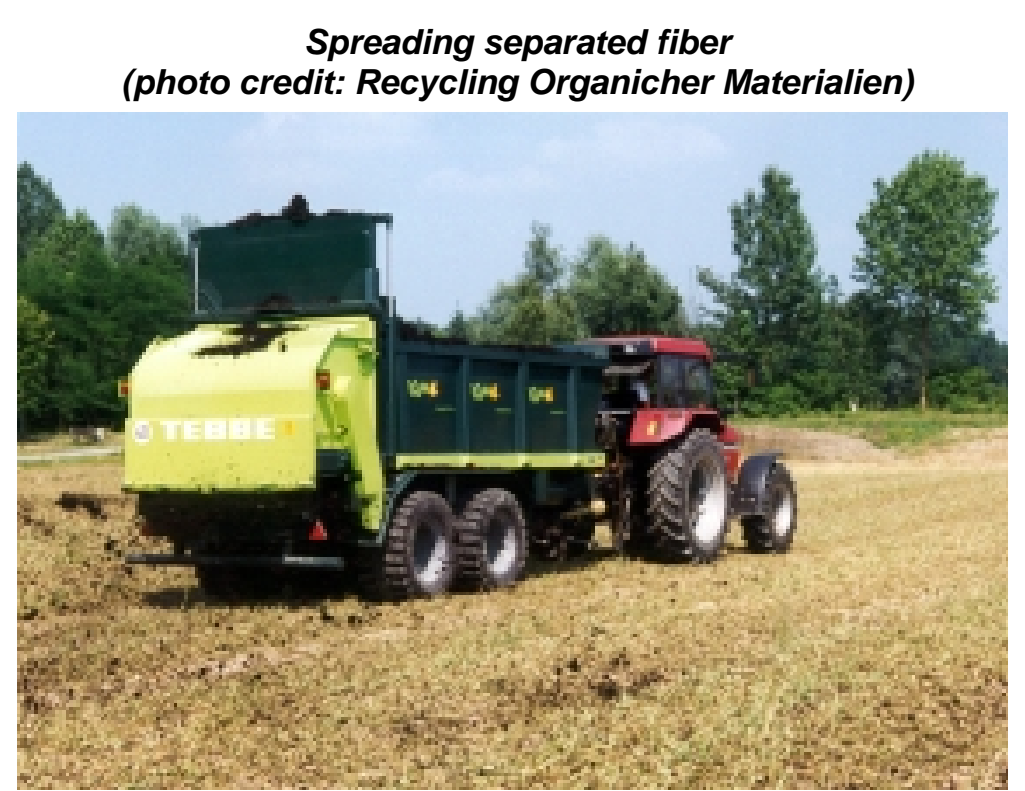
directly onto farmland for its nutrient value. Filtrate can also be further processed to provide a liquid material commonly called "centrate" and solid product called "cake."

In organic residues, much of the nitrogen is bound up in proteins and is not readily available to plants without undergoing biological conversion. During the digestion process, much of the organic bound nitrogen is reduced to dissolved ammonia by de-amination. Quite simply, during the digestion process, i.e., the degradation of organic materials, bacterial action results in the release of ammonia.

The filtrate's ammonia content can be higher, up to a factor of two more than in stored manure. However, little of the plant uptake of nitrogen is in the ammonia form; ammonia undergoes another step to produce nitrite, which in turn is converted to nitrate, the form most

\footnotetext{
${ }^{32}$ Supra, Note 31
} 
readily taken up by plants. Digestion does not reduce the quantities of nutrients; rather, the process converts them to new more soluble, and often more available, forms. "Digestion increases the availability of nitrogen... above its usual range of about 30\%-60\%, depending upon the time of year. The phosphate content is not decreased, and its availability of about $50 \%$ is not changed during digestion. Potash is usually available at 75\%-100\%."33

When the digester's ammonium effluent is spread on the ground, bacteria convert it into intermediate nitrite, which is then further converted into plant-usable nitrate. Plants typically convert about $3 \%$ of the available nitrogen into plant protein as happens with mineral fertilizers. The slow-release forms of bacterial-based protein nitrogen can also be very beneficial. Slow-release forms of nitrogen may increase plant nitrogen uptake. In Egyptian studies, ${ }^{34}$ the use of digested versus undigested manure was shown on sandy soils to produce an increase in crop yield of $1 \%$ per year continuously over a 15 -year period. This may be attributed to better soil structure.

Because ammonia is emitted easily after land application, there is a risk that filtrate ammonia will be more volatilized than raw manure during the first hours after spreading if it is not correctly applied. Proper land application means that the filtrate is spread as close to the ground as possible. For example, direct soil injection can reduce ammonia emissions by $85 \%-95 \%$ compared to spreading it with a splash-plate tanker. However, once the filtrate is applied, the risk of further ammonia losses is extremely small compared to raw manure, for three reasons: ${ }^{35}$

\section{Direct soil injection of filtrate allows nutrients to be recovered while simultaneously reducing volatile ammonia emissions (photo credit: Danish Energy Agency)}

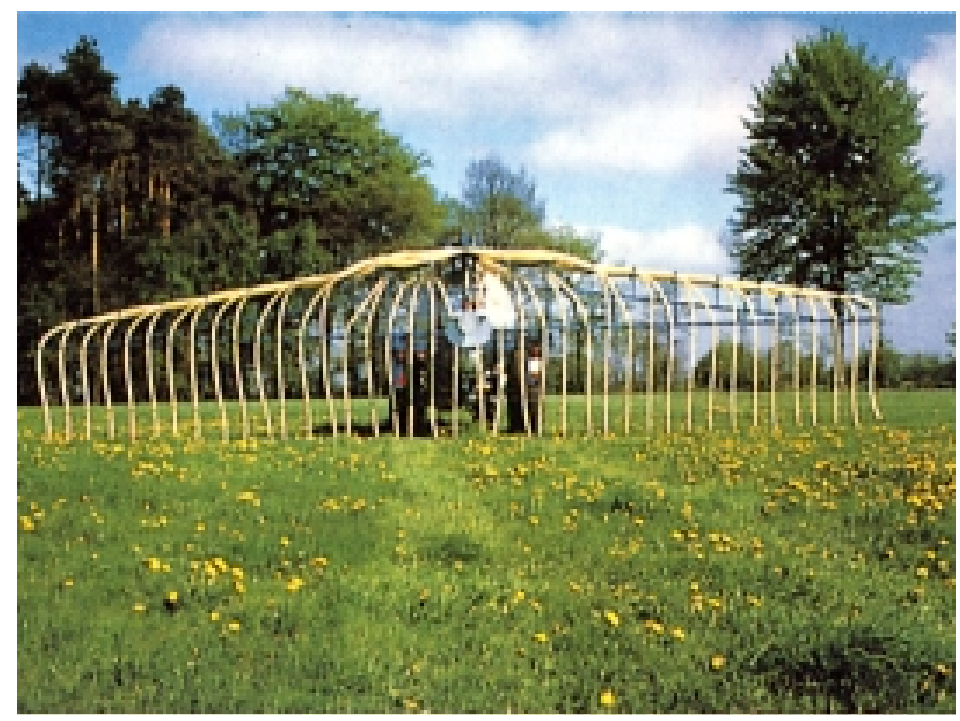

1) Due to the lower viscosity of the filtrate, it penetrates faster into the soil

2) Soil ammonium adsorption is high, hence washout is low, and;

3) Ammonia is more readily available to plants than organic nitrogen, i.e., the uptake through nitrification is faster and the chance for washout is reduced.

\footnotetext{
${ }^{33}$ Meynell, P-J. (1976). Methane: Planning a Digester. New York: Schocken Books. pp. 25.

${ }^{34}$ Gornall, L. (3 April 1998). Personal communication. Practically Green Environmental Services, Londonderry, Northern Ireland.

${ }^{35}$ Wellinger, A. (2 June 1998). Personal communication. NovaEnergie, Ettehhausen, Switzerland.
} 
Because it is low in volatile fatty acids and does not stick to the leaves, filtrate can be spread on growing plants (e.g., on corn as tall as 20 inches) with only minor risk of burning. As a result, the chance for atmospheric emissions will be even further reduced when filtrate is spread on growing plants.

Additionally, legumes such as clover and soybeans have root-dwelling bacteria on them that fix nitrogen. However, raw undigested manures spread on the ground make clover clump into small tight patches in grassland. By digesting manure, the acidic nature of the manure is reduced and clover runs root to root with the grass giving more opportunity for grass to be fed atmospheric nitrogen via the clover's underground nitrogen-fixing bacteria. ${ }^{36}$
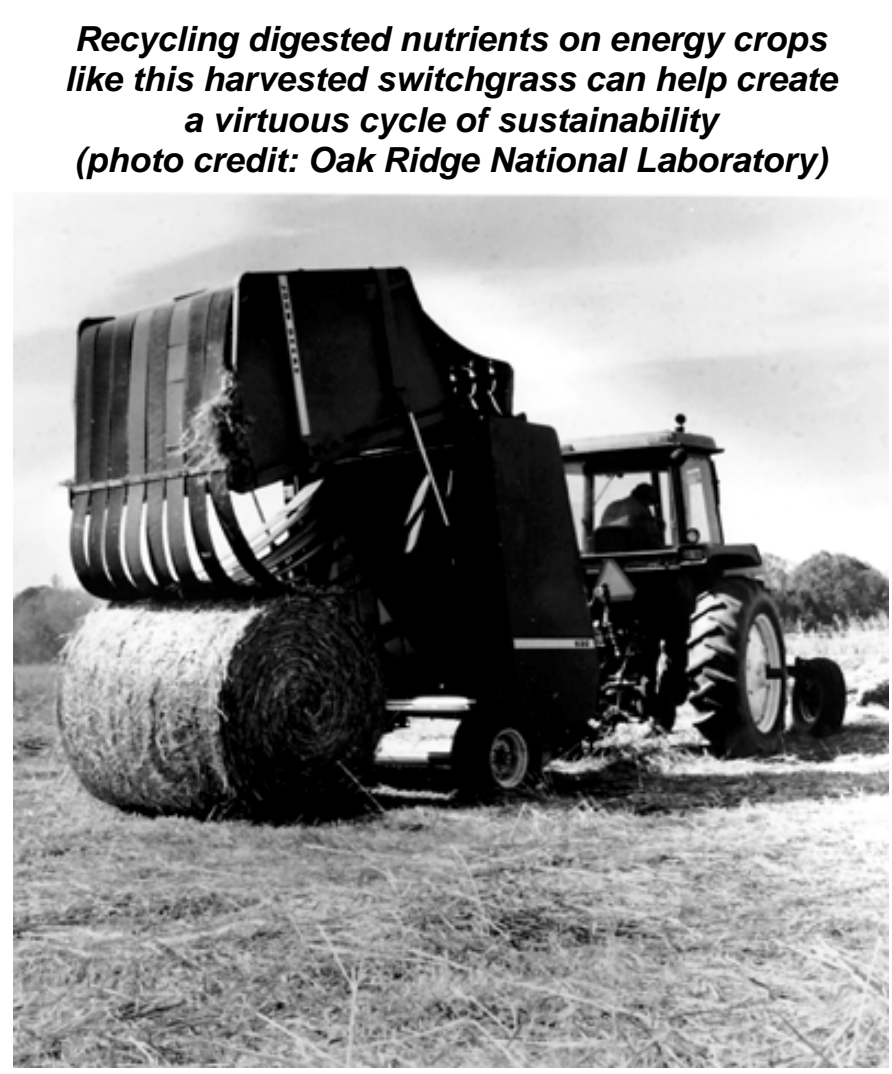

By using AD, it is possible to greatly reduce the use of traditional nutrients in soils. One study ${ }^{37}$ using data from the People's Republic of China reported $6 \%-20 \%$ greater yields using digester effluent to meet crop nutrient requirements. Additional research in the United States is necessary to better document the added availability of nutrients from digested organic residues. This is especially true when much of the current bioenergy focus in this county has the goal to develop and demonstrate environmentally acceptable energy crops and cropping systems for producing large quantities of low-cost, high-quality biomass feedstocks. AD can enrich alternative agricultural practices when the digestion residues are applied to energy crops and other dedicated feedstocks for the production of alternative fuels such as biodiesel or ethanol. Treating commodities to produce another energy yield while recycling nutrients creates a virtuous cycle of sustainability.

\subsection{Odor, Pathogens, and Anaerobic Digestion}

Odor from animal manures has become regarded as a nuisance in almost every state in the union. Although odorants are usually present at levels far below those considered to be toxic

\footnotetext{
${ }^{36}$ Gornall, L. (3 April 1998). Personal communication. Practically Green Environmental Services, Londonderry, Northern Ireland.

${ }^{37}$ Marchaim, U. (1992). Biogas Process for Sustainable Development. FAO Agricultural Service Bulletin 9-5. Rome, Italy: Food and Agriculture Organization.
} 
concentrations, odor concerns can be more serious than a disrupted weekend cookout. According to some, ${ }^{38}$ nearby residents of large-scale swine operations who experience these odors have less vigor and more tension, anger, depression, fatigue, and confusion.

Manure odors are caused principally by intermediate metabolites of anaerobic decomposition. "If odorous compounds are confined within the fermentation medium, many of the intermediary odorous compounds will be metabolized to less odorous compounds or to lower concentrations." 39 A common example is the properly designed anaerobic lagoon that, although not free of odors, is seldom the cause of an odor problem. Overloaded or shock-loaded lagoons become the source of many complaints when they become nothing more than biologically active manure storage pits.

AD by its very nature converts odor-causing materials in organic matter to methane and carbon dioxide, which are odorless. Generally, that which smells offensive is the prime food source for methane-producing bacteria. Odor reduction using anaerobic digesters can be a very costeffective alternative compared to aeration, chemicals, or enzyme treatments. "In fact, the biogas produced may be a by-product of a system designed for odor control." 40 As will be noted later in this report, odor control is probably the main reason livestock farmers have installed anaerobic digesters in the United States.

Experimental results show that flushed dairy manure odor after digestion is significantly less than that from undigested manure. As shown in Table 2.2, digestion reduced odor by $97 \%$. Short-term storage of flushed dairy manure, on the other hand, exacerbated odor by $77 \%$.

\begin{tabular}{|l|l|l|}
\hline \multicolumn{3}{|c|}{ TABLE 2.2: Effect of Fixed-Film Digestion at 3-day HRT } \\
on Flushed Dairy Manure Odor
\end{tabular}

* Threshold Odor Number

${ }^{38}$ Webb, D. (1998). "Alliance for a Responsible Swine Industry." Manure Management in Harmony with the Environment and Society; February 10-12, 1998; Ames, Iowa. Ames, IA: The Soil and Water Conservation Society, West North Central Region; pp. 313-314.

${ }^{39}$ Wilkie, A.C., et al. (1995). "Anaerobic Digestion for Odor Control." Nuisance Concerns in Animal Manure Management: Odors and Flies. H.H. Van Horn, ed. Gainesville, FL: Florida Cooperative Extension, University of Florida. pp. 56-62.

${ }^{40}$ Schulte, D. (1997). Swine Manure Digestion Systems. Lincoln, NE: Department of Biological Engineering, University of Nebraska.

${ }^{41}$ Wilkie, A.C. (1998). “Anaerobic Digestion of Livestock Wastes: A Suitable Approach to Odor Abatement.” The North Carolina 1998 Pork Conference and Beef Symposium; Raleigh, North Carolina. Raleigh, NC: North Carolina Pork Council; pp. 5-16. 
Animal manure represents a potential source of organisms that may be pathogenic to humans. One organism that has proven troublesome in recent years, Escherichia coli O157:H7, is known to originate primarily from ruminants such as cattle, which shed it through their feces. In addition, animal manure is known to harbor Salmonella, Cryptosporidium, and other pathogens. Therefore, the use of manure must be closely managed to limit the potential for pathogen contamination.

The potential to operate digesters at temperatures higher than $120^{\circ} \mathrm{F}$ makes the $\mathrm{AD}$ process particularly interesting for hygenization. Digesters can be designed to operate entirely at that temperature, or as a post-treatment step following operation at a lower temperature. Besides temperature, the anaerobic chemical environment multiplies the sanitation effect.

Recognizing this fact, and one of the first to do so, Danish law accepts AD as a hygienic measure for organic residue management. “...biogas plants have digestion tanks and sanitation tanks which can be operated to achieve a pathogen-reducing effect (PRE) in accordance with official requirements." 42 The Danes used the fecal streptococci (FS) method to evaluate sanitation effects, which is numerically expressed by the $\log _{10}$-reduction of the numbers of FS measured before and after digestion.

\begin{tabular}{|c|c|c|c|}
\hline \multicolumn{3}{|c|}{ TABLE 2.3: Controlled Sanitation Equivalents to $158^{\circ} \mathrm{F}$ for One Hour } \\
\hline Temperature & $\begin{array}{c}\text { Minimum } \\
\text { Guaranteed } \\
\text { Retention Time in } \\
\text { a Thermophilic } \\
\text { Digestion Tank }\end{array}$ & $\begin{array}{r}\text { Minimum Guaranteed Retention Time by } \\
\text { Treatment in a Separate Treatment Tank } \\
\text { Before/After }\end{array}$ \\
\cline { 2 - 4 } & thermophilic digestion & mesophilic digestion \\
\hline $125.6^{\circ} \mathrm{F}$ & 10 hours & \multicolumn{2}{|c|}{} \\
\hline $128.3^{\circ} \mathrm{F}$ & 8 hours & 5.5 hours & 7.5 hours \\
\hline $131.0^{\circ} \mathrm{F}$ & 6 hours & 2.5 hours & 3.5 hours \\
\hline $140.0^{\circ} \mathrm{F}$ & & 1.0 hours & 1.5 hours \\
\hline $149.0^{\circ} \mathrm{F}$ & & &
\end{tabular}

The PRE was examined in 10 centralized biogas plants during a 2-3 year period. The Danish research found that treating any digestible organic residue for 1 hour at a temperature of $158^{\circ} \mathrm{F}$ achieved a 4-log reduction in pathogens $(99.99 \%)$. The research also found that a number of equivalent time and temperature relationships also achieved a 4-log reduction (Table 2.3). There is some discussion in the European Union that the 1 hour $/ 158^{\circ} \mathrm{F}$ may be unwarranted. Some research efforts are underway to evaluate the consequences of a PRE using an 8 hour $/ 131^{\circ} \mathrm{F}$ standard. ${ }^{43}$ Also, a simple mesophilic digester can achieve a $95 \%$ PRE, which is virtually free of all common pathogens except for some viruses and helminths.

\footnotetext{
${ }^{42}$ Bendixon, H. (1996). "Hygiene and Sanitation Requirements in Danish Biogas Plants." Ninth European Bioenergy Conference; June 24-27, 1996, Copenhagen, Denmark. UK: Pergamon Press; pp. 296-301.

${ }^{43}$ Wheeler, P. (3 June 1998). Personal communication. Energy Technology Support Unit, Harwell, Oxon., UK.
} 
Thus, the risk of microbial contamination from digested manure can be significantly reduced compared to untreated manure. Some pathogens, such as the hepatitis A virus, have a higher thermal threshold than others. In addition, the time and temperature required to eliminate or reduce microbial hazards in manure or other organic materials may vary depending on climate and the specific management practices of an individual operation.

The toxic dinoflagellate, Pfiesteria piscicida, has been implicated as the primary causative agent of many major fish kills and fish disease events in estuaries, coastal areas, and aquaculture operations from the mid-Atlantic to the Gulf Coast. Fish kills caused by Pfiesteria usually occur in the warmest part of the year, and often precede low dissolved oxygen levels in the estuaries. Pfiesteria likely has been around for a long time (thousands of years) as a nontoxic predator on organisms like bacteria, algae, and small animals. Many experiments in the lab and field indicate, however, that human influences (e.g., excessive nutrient enrichment to poorly flushed estuarine ecosystems) have slowly shifted the environment to encourage Pfiesteria's fish-killing activity.

Research is continuing to focus on the nutritional ecology of Pfiesteria. Field and laboratory research has established that it can be highly stimulated by both inorganic and organic nitrogen and phosphorus enrichments. Researchers are examining interactions between organic and inorganic sources of nitrogen, phosphorus, and carbon in providing nutrition for Pfiesteria. This work involves both laboratory and field experiments. In related research, ${ }^{44}$ there is documentation that Pfiesteria is stimulated by both human sewage and swine effluent. Researchers are continuing to characterize the effects of these human-derived nutrient sources on production and toxic activity of this dinoflagellate.

Bovine spongiform encephalopathy (BSE) or "mad cow" disease is a condition of the same type as Kreutzfeld-Jakob in humans or scrapie in sheep. Even though the latter two have been known for some decades, the causal agent was only discovered a few years ago when the danger of BSE became more apparent. The agent is not a microorganism, a fungus or a virus. It is a simple protein named a prion, which cannot even be called an organism.

What is remarkable about prions is that they behave as infectious agents, but they are 100 times smaller than viruses and their mechanism of replication is unclear. ${ }^{45}$ The incubation period is extremely long, lasting several years to perhaps as many as 30 years in humans. Hence, the time between infection and disease outbreak makes it extremely difficult to spot the source of infection. Prions are extremely stable even under severe heat or chemical stress. Field trials showed that prions can survive as long as 6 years. The most secure way to destroy prions is either by incineration or by sterilization at 3 times

\footnotetext{
${ }^{44}$ Burkholder, J. (1997). Impacts of the Toxic Dinoflagellate, Pfiesteriapiscicida, on Estuarine Food Webs. NC State University, College of Agriculture and Life Sciences. The report is available at http://ww-w2.ncsu.edu/unity/lockers/project/aquatic-botony/pfiest.htrnl.

${ }^{45}$ Mad Cow \& Kreutzfeld-Jacob Disease Prions Defined. The report is available at http://www.sightings.com/health/prions.htm.
} 
atmospheric pressure and $270^{\circ} \mathrm{F}$ for 20 minutes. ${ }^{46}$ All the prion diseases are apparently associated with the accumulation in the brain of an abnormal protease-resistant isoform of the prion protein PrP. In other words, an abnormal variant of the normal PrP is somehow copied or produced by the disease process, which can be initiated by introducing infectious prions into the system. ${ }^{47}$

The relevance of this topic to biogas production is that prions are reportedly only released from an infected animal's brain, spinal cord, or eyes. In contrast to the scrapie virus, prions are not excreted with the placenta. Therefore, prions are probably not excreted in animal manures. As a result, digesters using manure or other agricultural feedstocks are not likely to be affected by the BSE problem. Even when feedstocks other than manures are digested, other viral or microbial diseases are not of concern to AD projects in Europe. ${ }^{48}$ All protein and fat-rich feedstocks derived from materials such as food wastes are still sanitized after the digestion process because controlled sanitation standards are based on a temperature of $158^{\circ} \mathrm{F}$ for a 1 hour period or equivalent. All other feedstocks, especially those from slaughterhouses, have to be sterilized before digestion. Brains, spinal cords, and eyes are collected separately and incinerated.

AD can play a role in treating liquid effluents from livestock operations. After digestion, nutrients are stabilized and pathogens can be reduced by $99.99 \%$. Normally, liquid products of digester treatment are land applied at agronomic rates acceptable for beneficial use. Should further treatment be desired, technologies are available to further reduce waste stream constituents. Aquatic vegetation such as algae or duckweed can be used as a secondary treatment system. High rates of nutrient removal are possible, and the algae or duckweed can then be composted or fed back to the livestock.

If additional treatment is necessary, excess nitrogen and phosphorus can be removed through biological methods, chemical precipitation, the use of membrane diffusion or ion exchange, or even ultraviolet light. However, these approaches are expensive both to install and to operate, requiring specially trained personnel. The cost-effective use of any secondary or tertiary technology dependents on the pretreatment and removal of suspended particulates and the reduction of compounds that will chemically or biologically bind oxygen. This situation occurs if organic residues are processed in an AD system.

\subsection{Follow the Methane}

The methane contained in biogas is a potent greenhouse gas. According to the Intergovernmental Panel on Climate Change (IPCC), the GWP is an attempt to provide a simple measure of various greenhouse gas emissions. The GWP of a gas reflects the cumulative radiative forcing of that gas over a specified period of time beginning the moment it is emitted. The GWP is expressed in terms of the radiative forcing of a gas to the forcing

\footnotetext{
${ }^{46}$ Wellinger, A. (23 May 1998). Personal communication. NovaEnergie, Ettenhausen, Switzerland.

${ }^{47}$ Supra, Note 45.

${ }^{48}$ Supra, Note 46
} 
associated with the same mass of carbon dioxide over the same time horizon. For example, carbon dioxide has a GWP of 1 .

The IPCC is constantly evaluating the GWP values of 44 gases, using a time-horizon of 100 years. The IPCC's most recent estimate of the GWP of methane was in 1996. Earlier IPCC estimates were published in 1992 and 1994. Changes in a GWP between 1992 and 1995 reflect the evolution of scientific understanding. For example, in 1992, methane's GWP was 11 times that of carbon dioxide. By 1994, new findings prompted the IPCC to more than double methane's GWP to 24.5. By 1996, ${ }^{49}$ the GWP had dropped to 21 . This means that a given mass of methane could increase the atmosphere's radiative forcing by an amount 21 times more than the forcing associated with the same mass of carbon dioxide. The EPA estimates that the atmospheric concentration of methane is increasing at $1 \%$ per year and has more than doubled over the past two centuries. ${ }^{50}$

With better management practices, methane from manure can be a clean, renewable source of energy. Moreover, based on life cycle cost analysis of proven methane recovery technologies such as slurry, covered lagoons, plug-flow and complete-mix digesters, an unavoidable livestock production liability can become a profit-making asset. Among manure handling systems, the potential rate of energy production from liquid-based systems is greater than for solid-based systems, because liquid-based systems encourage AD. Based on EPA estimates, ${ }^{51}$ liquid-based systems (anaerobic lagoons and liquid/slurry storage) account for $40 \%$ of U.S. methane emissions; solid-based systems (pasture/range, daily spread, solid storage, and drylots) account for the remaining $60 \%$.

One source $^{52}$ estimates that the difference in methane emission rates between liquid- and solidbased systems is even greater. Although only $28 \%$ of the nation's hogs are kept in facilities using anaerobic lagoons, these lagoon systems are estimated to emit $73 \%$ of the hog manure methane. According to this source, manure decomposing on pastures or fields emits only about $10 \%$ of the potential methane into the atmosphere. By contrast, emission rates for manure that decomposes in water as a result of hydraulic flushing can be as high as $90 \%$ of the total methane potential.

\footnotetext{
49 United Nations, Framework Convention on Climate Change. (1996). Subsidiary Body for Scientific and Technological Advice, National Communications. Geneva, Switzerland. The report is available at http://www.globalchange.org:80/sciall/96jul1d.htm.

50 Safley, L.M. et al. (1992). Global Methane Emissions From Livestock and Poultry Manure. Washington, DC: U.S. Environmental Protection Agency (EPA/400/1-91/048).

${ }^{51}$ US Environmental Protection Agency (1993). "Methane Emissions from Livestock Manure" Chapter 6 in Opportunities to Reduce Anthropogenic Methane Emissions in the United States: Report to Congress. Washington, DC: US Environmental Protection Agency (EPA-430-R-93-012); pp. 1-61.

52 Center for Rural Affairs. Manure Management in the European Pork Industry. August 1994 Newsletter. Walthill, NE.
} 


\subsection{ECONOMIC EVALUATION OF ANAEROBIC DIGESTION}

It is helpful to evaluate $\mathrm{AD}$ technologies using objective economic criteria. Options can then be ranked in terms of their relative cost-effectiveness, leading to rational deployment decisions. This section presents some economic evaluations of three types of digestion systems commonly found

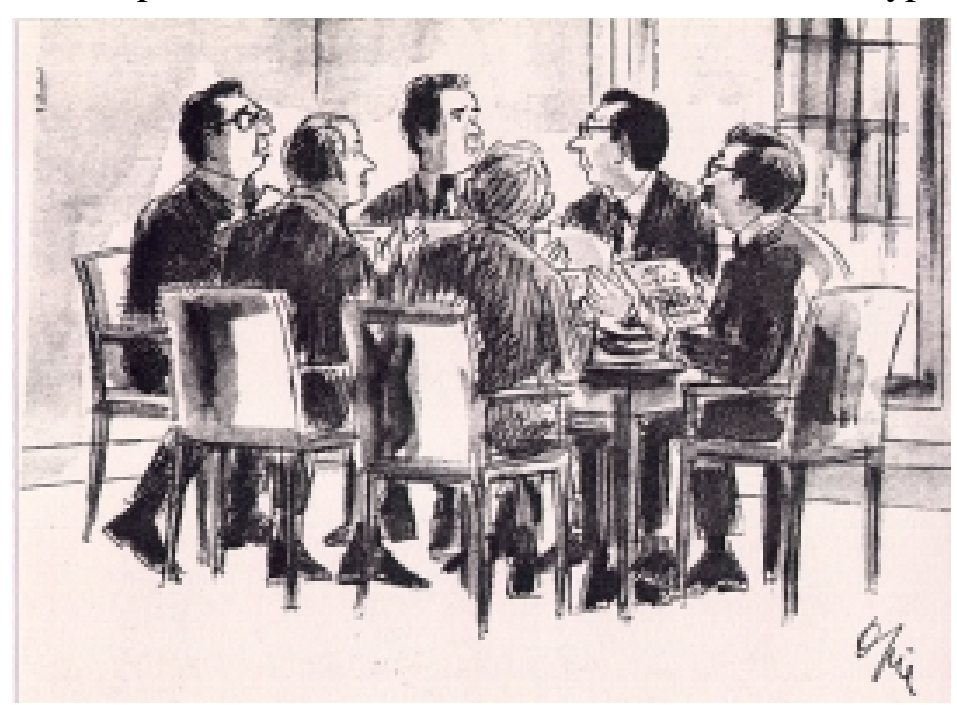

"McGuire, what's with you? Everybody else here seems to have a perfectly clear idea of what 'cost-effectiveness' means."

(C) September 1986 by The New Yorker

on dairy and swine farms; covered lagoon, plug-flow, and complete-mix. The digesters were assumed to use the biogas manufactured from the AD process to generate electricity.

Before proceeding, some preliminary economic concepts should be briefly discussed. The interrelationship of investment merit statistics is at the center of economic evaluation. The most readily understood statistic is cash flow. Cash flow is a schedule of annual net profit (or loss) resulting from an investment and can take into account such factors as amortization or the inflation rate for displaced fuels. The important point about cash flow is that "less money spent" is equal to "more money made." However, cash flow does not account for the time value of money.

The time value of money concept asserts that a current dollar is more valuable than a future dollar. To assess true profitability, cash flows must be adjusted by the discount rate to put dollars into a consistent present value. The discount rate can be interpreted as the interest rate anticipated on an alternate investment opportunity, against which the original opportunity is compared to evaluate the financial consequence of going with the original. The interrelationship of these investment merit statistics is discussed below.

Simple payback period (SPP) is often used as a criterion for determining investment acceptability. From cash flow, a SPP for the investment can be quickly calculated. SPP is the "break-even" length of time necessary to recover the initial investment through positive cash flow. Many businesses will only undertake investments with a 2-year SPP. However, although payback may be useful in measuring the liquidity of an investment, it offers no real insight on profitability because the analysis is incomplete. Neither the time value of money nor positive cash flow occurring after the payback period is accounted for. Hence, for mutually exclusive projects with equal cash flows, the project with an infinite lifetime would receive the same ranking as a project with a very short lifetime if both had the same payback period.

Net present value (NPV) is an investment merit statistic that accounts for the time value of money by describing the present worth of an investment in dollars. It is calculated by the compound 
discounting of the investment's annual cash flow with a specified discount rate, then totaling the discounted cash flows over the investment life to arrive at its net value. If NPV is a positive figure, the investment provides a greater return than the alternate choice assumed by the discount rate. If the NPV is a negative figure, the alternate presents the better opportunity. If NPV equals zero, it is said the choices are indifferent. When there is more than one competing investment, the higher NPV is preferred. However, in a capital rationing situation, NPV has an inherent bias in favor of large projects.

Internal rate of return (IRR) is related to NPV: it is the percentage figure of the discount rate that yields a zero NPV. IRR allows direct comparison between the returns offered by various investment opportunities. If the IRR from a new investment is greater than the discount rate offered by an alternate choice, the new investment is more worthwhile. However, IRR suffers in two areas. First, if a project has a cash outflow at its end, there are multiple rates of return. Although this is not the case with the data analyzed, the situation occurs, for example, in circumstances where there are abandonment costs. Second, a bias is introduced in the implicit assumption that all positive cash flows are reinvested over the remaining project life at the calculated IRR. "This may be an unrealistic assumption, especially for projects with relatively high Internal Rates of Return. While this does not affect the decision to accept or reject a project, it does affect the relative ranking of projects when comparing their relative profitability."1

Although the IRR and NPV methods will lead to the same decision whether to accept or reject a project, they can provide conflicting clues when the decision is a choice between mutually exclusive projects. That is, one project can have a higher IRR but a lower NPV. This problem arises because the IRR is the implied reinvestment rate in the IRR method; the discount rate is the implicit reinvestment rate used in the NPV method. NPV is generally superior because reinvestment will likely occur at a rate close to the cost of capital.

One area of potential concern relates to discount rate. Without belaboring the point, the choice of a discount rate is essential to the outcome: what may appear to be justified with a low discount rate may be imprudent at a higher rate. There are a number of problems with estimating a discount rate for farm-based technologies. Basic questions arise; for example, what is a true discount rate for livestock producers? What level of risk, and hence discount rate, does the investment in $\mathrm{AD}$ technology really represent? The range could lie between the yield of the risk-free investments made by the Treasury Department to that of a more speculative junk bond. Finally, private sector externalities are not accounted for within the discount rate. Mitigation of environmental externalities, especially odor control, can be the major factors leading to an investment in $\mathrm{AD}$ technology.

Pro forma economic evaluations of investment decisions can lead to far different conclusions than pro forma evaluations of financing decisions. Although the specific reasons for this are beyond the scope of this paper, this is due to timing of cash flows in an analysis. In an economic evaluation all investment outlays are recorded in "time-zero," which corresponds to the beginning

\footnotetext{
${ }^{1}$ McGuigan, J.; Moyer, R. (1975). Managerial Economics: Private and Public Sector Decision Analysis. Hinsdale, IL: The Dryden Press; pp. 554-555.
} 
of the first year of a project and are never discounted. In a financing evaluation, it is possible to have cash receipts in "time-zero" that are placed in discountable future years of a project. Hence, an economic evaluation is a much more conservative approach for evaluating investment opportunities. Quite simply, some projects in this world are financed that do not appear to be cost-effective.

\subsection{Covered Anaerobic Lagoon Digester Profile}

This section provides a detailed economic profile of one type of digestion system that could be found on many swine farms: a covered anaerobic lagoon. The digester was assumed to be located in North Carolina, a major swine-producing state. Electricity generation with waste heat recovery was assumed to be the end-use application of the biogas manufactured by the anaerobic process.

The first objective of the profile is to develop an estimate of its cost and energy production potential. This was primarily accomplished by using the EPA's AgSTAR FarmWare ${ }^{2}$ computer program. A second study objective was to evaluate the life-cycle economic performance of the digestion system, and to conduct a sensitivity analysis of two key economic performance statistics as functions of electricity rates.

To accomplish the second objective, the digester cost and energy production data, as well as additional variables, were linked into CashFlow ${ }^{\circledR}$, a model that provides the investment merit statistics NPV, IRR, SPP, and cumulative cash flow (CCF). The variables used in the analyses are listed in Table 3.1 and include nominal growth rate in O\&M expenses, nominal growth rate in energy expenses, nominal discount rate, percent combined tax rate, depreciation of system capital costs method, and project life.

The values for nominal growth rates in energy expenses were based on the 5-year moving average of the percentage change in the national retail prices of electricity sold by electric utilities. ${ }^{3}$

Nominal O\&M expenses were based on a 5-year moving average of the Producer Price Index $^{4}$ for motor generator sets and switchgear equipment. As shown, the major materials required for O\&M rose at a positive rate slightly higher than energy prices.

It was beyond the scope of this section to delineate the "true" discount rate for livestock producers, so the discount rate was assumed to be the prime interest rate plus $6 \%$. This "rule-ofthumb" helps to simplify the issue of how to incorporate investment risk. At the time this study section was written, the prime rate of interest was $8.25 \%$. Thus, the nominal discount rate used was $14.25 \%$.

Another significant assumption used was in the area of depreciation of capital equipment. Following the expiration of the business and energy tax credits with the passage of the federal

${ }^{2}$ U.S. Environmental Protection Agency (1995). FarmWare User's Manual Version 1.02. Washington, DC: U.S. Environmental Protection Agency. EPA-430-B-95-015.

${ }^{3}$ Energy Information Administration (1995). Annual Energy Review 1994. Washington, DC: U.S. Department of Energy.

${ }^{4}$ U.S. Bureau of Labor Statistics (1995). Producer Prices Indexe. Washington, DC: U.S. Department of Commerce. 
Tax Reform Act of 1986, depreciation of capital equipment is one of the few incentives which can legitimately increase the economic performance of AD technologies.

After review of Internal Revenue Service publications, ${ }^{5,6}$ the 7-year $150 \%$ declining balance general depreciation system (150\% DB-GDS) election offered under the modified accelerated cost recovery system (MACRS) was used. The depreciation method and time period was one choice under the MACRS. Although it appears that the 200\% double DB-GDS can also be used in situations involving ownership by an unrelated party, the $150 \%$ DB-GDS is directed toward farm rather than non-farm property classes. As with all matters related to taxes, a competent accountant or attorney should be consulted to maximize all legitimate incentives.

Because there is not much long-term experience using covered lagoon digesters in North Carolina, the last area of uncertainty relates to project life. As will be shown in the next section, a number of swine farm covered lagoon digesters have demonstrated practical lives longer than 10 years. Based on this objective evidence, it was assumed that a well-designed and maintained covered lagoon digester had a project life of 15 years.

There were a number of other smaller-impact assumptions. To be conservative in estimating tax rates, this study assumed a 32\% combined tax rate. All financial exchanges were assumed to be "cash-and-carry" with no budget constraints. This study assumed a zero salvage value of all capital equipment. The last implicit macro assumption was in the use of the end-of-year convention. It was assumed that all project capital costs were incurred during Time 0 .

\section{TABLE 3.1: Macro CashFlow Variables}

O\&M Nominal Growth Rate

Energy Expense Nominal Growth Rate

Nominal Discount Rate

$14.25 \%$

Marginal Tax Rate

Depreciation Method

$32.0 \%$

Project Life

7-Year 150\% DB-GDS

15 Years

\subsubsection{Base Water Usage Digester Cost and Energy Estimates}

For the purpose of estimating capital cost and energy production rates, the covered lagoon digester was assumed to be located in Duplin County, North Carolina. The next step was estimating herd size, which refers to the number of on-farm animals. The herd size information was obtained from a design report ${ }^{7}$ used to size a covered lagoon digester on a "typical" 1000sow farrow-to-finish swine farm. The farm population (sows, nursery, grower, finisher, and boars) was 11,474 animals with a total live animal weight (LAW) of 1,558,808 lb.

${ }^{5}$ Internal Revenue Service (1996). Publication 534: Depreciation. Washington, DC: Internal Revenue Service.

6 Internal Revenue Service (1996). Publication 946: Depreciating Your Property. Washington, DC: Internal Revenue Service.

${ }^{7}$ Safley, L.M.; Crawford, S. (1992). Carroll's Foods Farm \#37 Biogas Project: Low Temperature Lagoon Digester Preliminary Design Report. Raleigh, NC: NC Energy Division, Department of Commerce. 
According to the design report, the farm's waste management system incorporates a conventional anaerobic lagoon supplied by a hydraulic flush system consisting of 31840 -gal flush tanks that each operate on a 2-hour cycle (i.e., 12 cycles/day). Thus, every day the farm uses a total flush volume of 312,480 gal of water, giving the effluent a $0.3 \%$ TS concentration. It was assumed that all manure generated was collected. With these inputs, FarmWare estimated that the total amount of manure collected was $170,539 \mathrm{lb} / \mathrm{d}$. With an average volatile solids ${ }^{8}$ (VS) production of around $5.4 \mathrm{lb} / 1,000 \mathrm{lb} \mathrm{LAW}$, the FarmWare program estimated that the total daily VS production was $8,340 \mathrm{lb}$.

The next step was to obtain an estimate of the lagoon size. The key values for determining lagoon size are HRT and loading rate. The assumption was to let the FarmWare program select the default between a HRT of 40 days or a loading rate of $10 \mathrm{lb} \mathrm{VS} / 1,000 \mathrm{ft}^{3}$ of digester volume, fairly standard for preliminarily lagoon size estimates.

Using these key variables and a number of other implicit assumptions found in the FarmWare program, the total lagoon volume was estimated to be 2.02 million $\mathrm{ft}^{3}$. Assuming a depth of $24 \mathrm{ft}$, the linear surface dimensions were estimated to be $348 \times 348 \mathrm{ft}$, presenting a total surface area of $121,104 \mathrm{ft}^{2}$ to be covered with an industrial fabric such as HDPE or XR-5.

FarmWare estimated that the digester would, on average, produce $32,401 \mathrm{ft}^{3}$ of methane/day. The program estimated that this would be sufficient to fuel an engine/generator of $113-\mathrm{kW}$. With a heat rate of $14,000 \mathrm{Btu} / \mathrm{kWh}$, daily electricity production was estimated to be $2,592 \mathrm{kWh} /$ day. Assuming an annual capacity factor of $90 \%$, it was estimated that $851,472 \mathrm{kWh}$ could be produced during the course of a year.

A tremendous amount of thermal energy is produced by combusting biogas in an engine/generator, and much of this energy is available for recovery. On a swine farm, heat is commonly used for the nursery and other barns for almost the entire year. To help maximize coproduct use, it was also assumed that the hot air produced from engine cooling was ducted into the hog buildings to provide space heat. As will be discussed in the next section, this type of hot air recovery system has been used successfully for more than 10 years on several farms in California. Assuming that 2,800 Btu can be recovered per $\mathrm{kWh}$ generated, and that space heat was required for 9 months in the course of the year, 1.79 million Btu could be recovered.

Excluding the cost of lagoon construction, the digester capital costing information represented the total "turn key" cost of all materials, labor, and engineering services required to bring a project on-line. Engineering costs were estimated to be $\$ 25,000$. The cost of constructing the digester was estimated to be $\$ 224,519$, including the cost of the cover, as well as all gas handling and transmission costs. The engine and induction generator were estimated to cost $\$ 82,800$, including the switchgear and intertie components required by most electric utilities. The add-on hot air recovery system was estimated to cost $\$ 25 / \mathrm{kW}$ of engine capacity, a total of $\$ 2,825$. Thus, the total capital expense was estimated to be $\$ 335,114$.

\footnotetext{
${ }^{8}$ n.b., VS is the organic fraction of TS, of which a portion is converted into biogas.
} 
Engine O\&M costs were estimated to be $\$ 0.0125 / \mathrm{kWh}$ of electricity generated. ${ }^{9}$ Because a covered lagoon is a passive technology, it requires little or no maintenance other than a daily visual inspection. This was estimated to bring total O\&M costs to $\$ 0.015 \phi / \mathrm{kWh}$ of electricity generated, an annual expense of $\$ 12,772$ during the first year of operation.

In determining the offset cost of purchased power, the electricity rate used was representative of rates in Duplin County, North Carolina. To help simplify analysis, electric rates were assumed to be a blend of demand and energy charges. Based on a review of Rate Schedule 6 for Large Power Service offered by the Electric Membership Corporations in this area of North Carolina, this project would offset an average of about $\$ 0.068 / \mathrm{kWh}$. Given the total $\mathrm{kWh}$ generated during the course of a year, this system could offset enough purchased power to save $\$ 57,900$ during the first year of operation. The value of the hot air recovery system was based on offsetting purchased propane that was assumed to cost $\$ 0.75 \varnothing /$ gal. This translates into a cost of about $\$ 8.21 / \mathrm{million}$ Btu. Given the total amount of hot air recovered during the course of a year, this system could provide a saving of $\$ 14,679$ in propane costs during the first year of operation. Thus, the net first year savings (i.e., less O\&M) are estimated to be $\$ 59,857$.

\subsubsection{Base Water Usage Digester Economic Evaluation}

The value of the digester was a function of how the energy was used; in other words, the direct energy costs avoided by the farmer. The assumed value of the digester was established by the amount of electricity generated and reclaimed heat used on the farm to offset currently purchased power and space heating fuels. No credit was assumed for reducing environmental externalities.

Table 3.2 provides the investment merit statistics for the base water usage project. The positive NPV indicates that the technology has investment merit. Implementing the covered lagoon digester project would add more than $\$ 440,000$ in net farm income during its life. The technique provides a SPP of about 5.3 years. However, as shown in the sensitivity of IRR to average cost of electricity per kWh (Figure 3.1), below an electric rate of $\$ 0.068 / \mathrm{kWh}$, the system quickly loses its investment merit.

\section{TABLE 3.2: Covered Lagoon Digester Base Water Usage Economic Summary}

NPV

IRR (\%)

SPP (years)

CCF (\$)
$\$ 7,543$

$14.5 \%$

5.3 years

$\$ 443,362$

\footnotetext{
9 Ross, C., et al. (1996). Handbook of Biogas Utilization, Second Edition. Muscle Shoals, AL: Southeastern Regional Biomass Energy Program.
} 
FIGURE 3.1: Sensitivity of IRR and SPP to Electricity Rate

for Base Water Usage Swine Farm

Covered Lagoon Digester with Heat Recovery

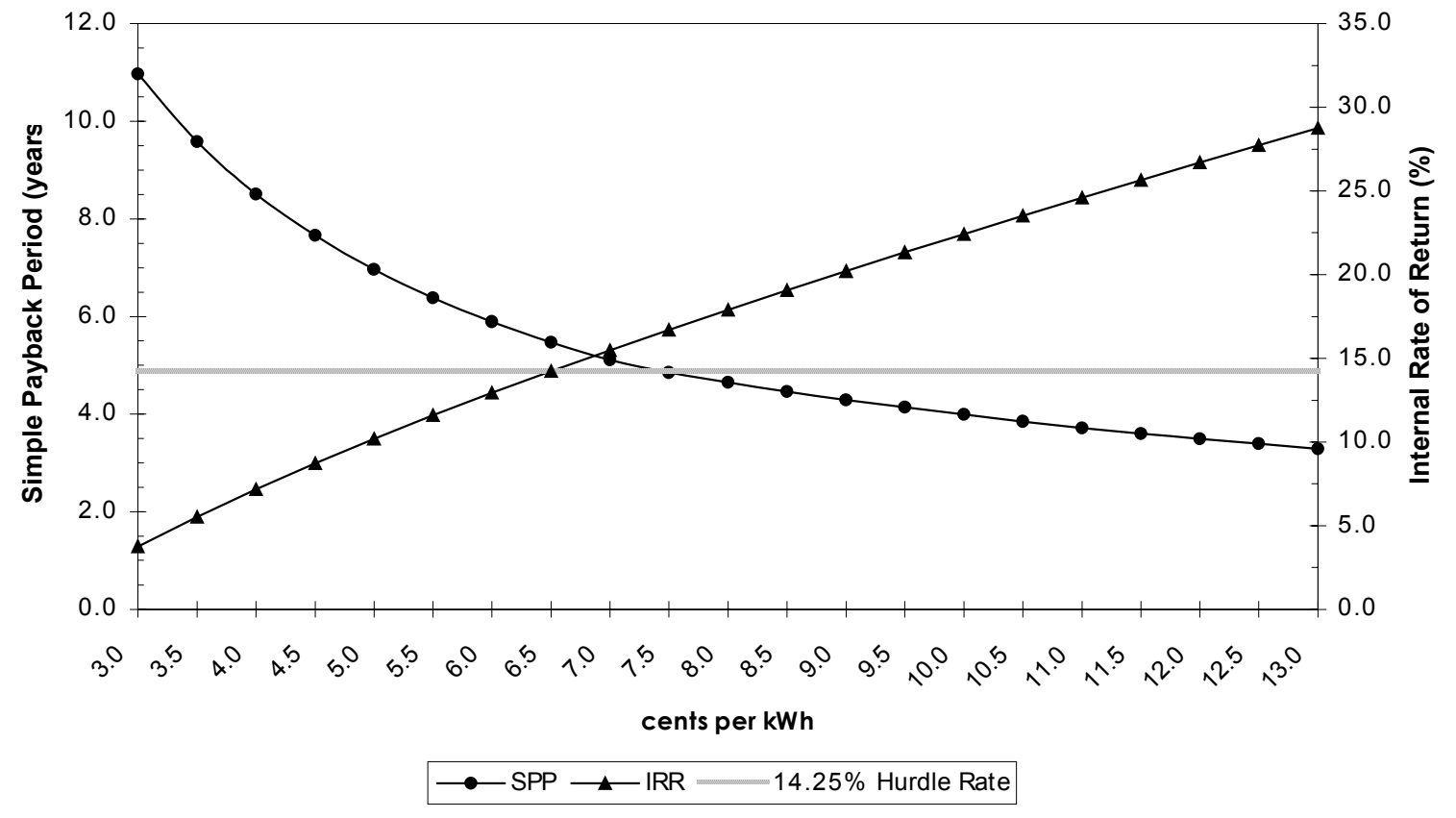

\subsubsection{Reduced Water Usage Cost and Energy Estimates}

As shown earlier, the base water usage by the farm's waste management system incorporates a conventional anaerobic lagoon supplied by a system that cycles 12 times daily, producing a total flush volume of 312,480 gal of water with a $0.3 \%$ TS concentration. One observation is that other swine farms successfully operate with far fewer daily flushing cycles without compromising animal health or worker safety. Many farms flush four to six times daily, some flush infrequently as twice per day.

All other things being held equal, fewer daily flushing cycles would allow a smaller, less costly, covered lagoon digestion system to be installed. The net impact should be an increase in costeffectiveness. The purpose here is to illustrate the impacts of reduced water usage on the economic performance of the digestion system. Thus, except for reducing the number of daily flushing cycles from 12 to 8 (i.e., flushing every 3 hours instead of every 2 hours), all the other inputs previously used remained constant. This would provide a flush volume of 208,320 gal/day, giving a $0.45 \%$ TS concentration.

Using these variables and, once again, the other implicit assumptions found in the FarmWare program indicated that the total lagoon volume would be reduced from 2.02 to 1.40 million $\mathrm{ft}^{3}$. Still assuming a depth of 24 feet, the linear surface dimensions were estimated to be $299 \times 299 \mathrm{ft}$, presenting a total surface area of $89,401 \mathrm{ft}^{2}$ to be covered.

FarmWare estimated that the digester would, on average, produce $32,429 \mathrm{ft}^{3}$ of methane per day. The program still estimated that this would be sufficient to fuel an engine/generator of 113-kW. 
With a heat rate of $14,000 \mathrm{Btu} / \mathrm{kWh}$, daily electricity production was estimated to be 2,594 $\mathrm{kWh} /$ day. Assuming a capacity factor of $90 \%$, it was estimated that $852,129 \mathrm{kWh}$ could be produced during the course of a year. Still assuming that 2,800 Btu can be recovered per kWh generated, and that space heat was required for 9 months in the course of the year, 1.79 million Btu could be recovered for heating purposes. Basically, energy production remained unchanged from the base analysis.

Once again excluding the cost of lagoon construction, the digester capital costing information represented the total "turn key" cost required to bring a project on-line. Engineering costs were still estimated to be $\$ 25,000$. The cost of the digester was estimated to be $\$ 168,352$, including the cost of the cover, as well as all gas handling and transmission costs. The engine and induction generator were still estimated to cost $\$ 82,800$, including the intertie components required by most electric utilities. The add-on hot air recovery system was still estimated to cost $\$ 2,825$. Thus, the total capital expense was estimated to be $\$ 278,977$. This was a reduction in capital costs of $\$ 56,137$, about $17 \%$ lower than the base water usage digester costs.

In determining the avoided cost of purchased power, the electricity rate was still assumed to be an average of about $\$ 0.068 / \mathrm{kWh}$. Given the $\mathrm{kWh}$ generated during the course of a year, this system could offset purchased power that results in a saving of $\$ 57,955$ during the first year of operation. The value of the hot air recovery system was still based on offsetting purchased propane, which was assumed to cost about $\$ 8.21 /$ million Btu. Given the total amount of hot air recovered during the course of a year, this system could offset purchased propane that results in a saving of $\$ 14,688$ during the first year of operation. Total O\&M costs were still estimated to be $\$ 0.015 / \mathrm{kWh}$ of electricity generated, an annual expense of $\$ 12,782$. Thus, the net first year savings (i.e., less O\&M) are estimated to be $\$ 59,861$. Basically, revenues received from energy production remained unchanged from the base analysis.

\subsubsection{Reduced Water Usage Digester Economic Evaluation}

Once again, the value of the digester was a function of how the energy was used; in other words, the direct energy costs avoided by the farmer. The assumed value of the digester was established by the amount of electricity generated and heat reclaimed from the engine/generator used on the farm to offset currently purchased power and space heating fuels.

Table 3.3 provides the investment merit statistics for the reduced water usage digester project. The positive NPV indicates that the technology has investment merit. Implementation of the covered lagoon project would add more than $\$ 481,000$ in net farm income during its life. The reduced water usage technique provides a SPP of about 4.6 years. As shown in Figure 3.2, which displays the sensitivity of IRR to the average cost of electricity per $\mathrm{kWh}$, the system now loses its economic merit only when rates are lower than $\$ 0 / 055 / \mathrm{kWh}$. The simple reduction in water usage increased economic performance as measured by IRR by $23 \%$. 
TABLE 3.3: Covered Lagoon Digester Reduced Water Usage Economic Summary

\begin{tabular}{|lr|} 
NPV & $\$ 47,744$ \\
IRR & $17.9 \%$ \\
SPP & 4.6 years \\
CCF & $\$ 481,944$ \\
\hline
\end{tabular}

FIGURE 3.2: Sensitivity of IRR and SPP to Electricity Rate

for Reduced Water Usage Swine Farm

Covered Lagoon Digester with Heat Recovery

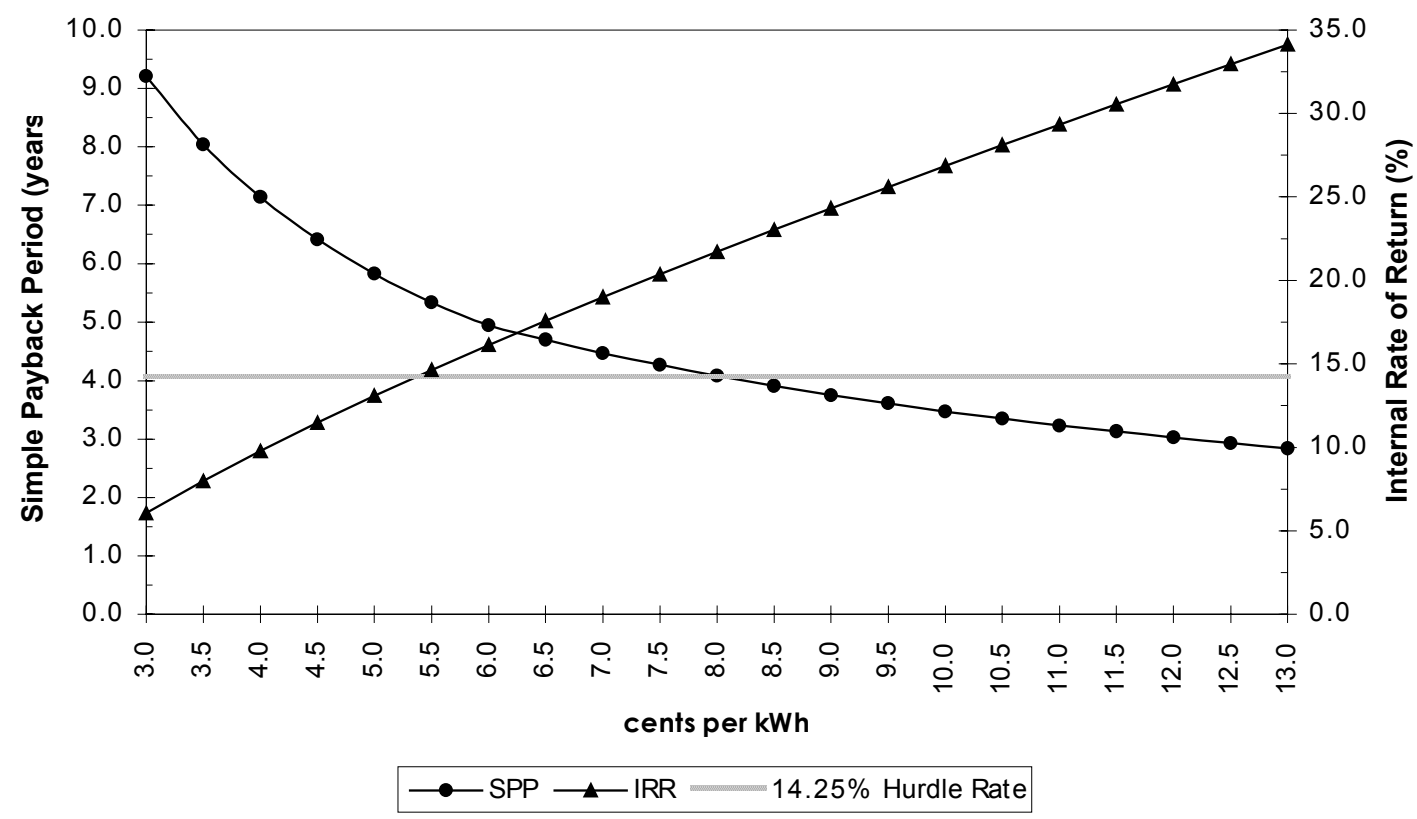

\subsection{Plug-Flow Digester Profile}

This section provides a detailed economic profile of one type of system that could be found on many dairy farms: a plug-flow digester. The digester was assumed to be located in New York, a major milk-producing state. Electricity generation with waste heat recovery was assumed to be the end-use application of the biogas produced from the anaerobic process. Like the covered lagoon profile, the first objective is to develop an estimate of its cost and energy production potential. This was partially accomplished by using the FarmWare ${ }^{10}$ computer program. A second study objective was to evaluate the life-cycle economic performance of the digestion system.

To accomplish the second objective, the digester cost and energy production data, as well as additional variables, were linked into $\mathrm{CashFlow}^{(}{ }^{\circ}$, a model that provides the investment merit statistics NPV, IRR, SPP, and CCF. Except for project life, the variables used in the analyses are

\footnotetext{
${ }^{10}$ U.S. Environmental Protection Agency (1995). FarmWare User's Manual Version 1.02. Washington, DC: U.S. Environmental Protection Agency. EPA-430-B-95-015.
} 
the same as those listed in Table 3.1. As will be shown in the next section, a number of plug-flow digesters have demonstrated practical lives longer than 15 years. Based on this objective evidence, it was assumed that a well-designed and maintained plug-flow digester had a project life of 20 years.

\subsubsection{Digester Size and Product Estimates}

For the purpose of estimating capital cost and energy production rates, the plug-flow digester was assumed to be located in Tioga County, New York. The next step was estimating herd size, which in this situation refers to the number of animals supplying the digestion system. The herd size was assumed to be 500 Holstein dairy cows with a total LAW of 700,000 lb.

The farm's manure management was assumed to be a scrape system. Under its plug-flow analysis, the FarmWare program apparently does not factor in any flushing that may occur in the milking parlor. Although it is usually recommended that dairy operations segregate parlor water from the digester, this inconsistency in the FarmWare program could compromise the resulting investigations. Many analysts use proprietary programs that incorporate any hydraulic flushing occurring in the milking parlor. Given this caveat, FarmWare made a preliminary estimate that the total amount of manure collected was $56,000 \mathrm{lb} /$ day. With an average VS production of 8.5 $\mathrm{lb} / 1,000 \mathrm{lb} \mathrm{LAW}$, the FarmWare program estimated that the total daily VS production was 5,950 lb. It was assumed that all the manure generated was collected and that the manure had a $12.5 \%$ TS concentration.

The next step was to estimate digester size. The key values for determining digester size are HRT and loading rate. The assumption was to let the FarmWare program use a default HRT of 20 days, fairly standard for preliminarily estimates of digester size. At this point it became apparent that there is a secondary "bug" in the FarmWare program that does not account at all for manure deposited in the milking parlor. As a result, the program underestimates all values such as biogas production by about $12.5 \%$ in its final analyses.

It was then necessary to develop a spreadsheet using some of the key FarmWare variables and the Agricultural Waste Management Field Handbook ${ }^{11}$ to estimate digester size and biogas production. The total digester volume was estimated to be $22,227 \mathrm{ft}^{3}$. Assuming a depth of $10 \mathrm{ft}$, the linear surface dimensions were estimated to be $106 \times 21 \mathrm{ft}$, presenting a total surface area of $2,223 \mathrm{ft}^{2}$ to be covered with an industrial fabric like HDPE or XR-5.

The analysis estimated that the digester would, on average, produce $35,700 \mathrm{ft}^{3}$ of biogas per day. The spreadsheet estimated that this would be enough to fuel a $67-\mathrm{kW}$ engine/generator. With a heat rate of $14,000 \mathrm{Btu} / \mathrm{kWh}$, daily electricity production was estimated to be $1,607 \mathrm{kWh}$. Assuming an annual capacity factor of $80 \%$ and subtracting for the parasitic losses required for the digester's electrical equipment like mixing motors and solids separators, it was estimated that a net of 452,980 kWh could be produced annually.

\footnotetext{
${ }^{11}$ Natural Resource Conservation Service (1992). Agricultural Waste Management Field Handbook 210$A W M F H$. Washington DC: U.S. Department of Agriculture.
} 
Thermal energy produced by combusting biogas in an engine/generator is also recoverable. On a dairy farm, hot water is commonly used for sanitary washing throughout the entire year. Thermal energy can also be used for space heating offices and nearby buildings, as well as for other uses such as preheating livestock drinking water. Assuming that 3,750 Btu can be recovered per $\mathrm{kWh}$ generated and that $60 \%$ of this available energy was used during the year, 10.48 million Btu could be recovered.

Excluding water vapor, the hypothetical outputs for the scenario is presented in terms of tons/year in Table 3.4 and graphically by percentage in Figure 3.3. Because of multiple rounding errors, about 4 more tons of output is created than was input annually, an error of $0.04 \%$.

\begin{tabular}{|lr|}
\hline \multicolumn{2}{|c|}{ TABLE 3.4: Plug-Flow Digester Hypothetical Outputs (Tons/Year) } \\
\hline Methane & 182 \\
Carbon Dioxide & 302 \\
Grit & 103 \\
Fiber & 1,422 \\
Filtrate & $\underline{\mathbf{8 , 2 1 5}}$ \\
TOTAL & $\mathbf{1 0 , 2 2 4}$ \\
\hline
\end{tabular}

FIGURE 3.3: Hypothetical Dairy Farm Plug-Flow Digester

Outputs by Percent

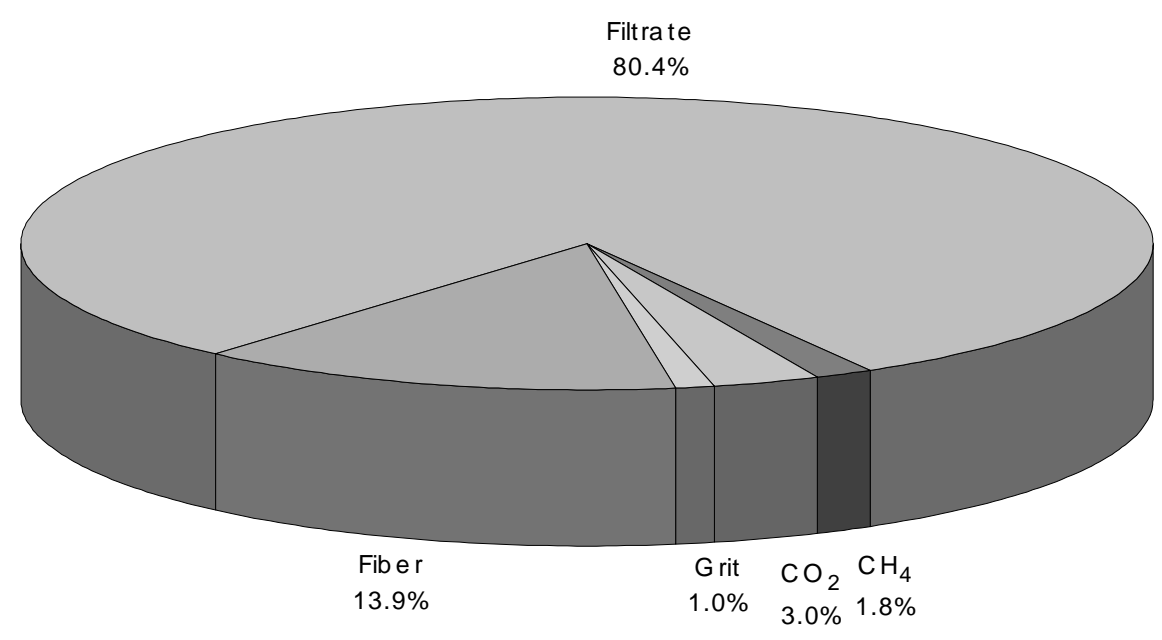


As adapted from the Handbook of Biogas Utilization ${ }^{12}$, the annual air emissions from the system are provided in Table 3.5. One item worth mentioning is on air the emission calculations for particulates, nitrogen oxides, and carbon monoxide. These pollutants are computed using the AP42 emission factors published by the EPA for natural gas. These factors predict emissions per million cubic feet of natural gas combusted, and the results listed in Table 3.5 use the methane content of the biogas. The calculation of sulfur dioxide emissions is a two-step process: first, the emissions of hydrogen sulfide from the biogas must be calculated and converted into sulfur dioxide, and second, the sulfur dioxide emissions from an equivalent volume of natural gas are calculated per AP-42. These are summed to provide the total amount of sulfur dioxide emitted.

\section{TABLE 3.5: Plug-Flow Digester Air Emissions Estimator}

\begin{tabular}{|c|c|}
\hline PARAMETER & QUANTITY \\
\hline Biogas Produced & 35,700 SCF/day \\
\hline System Operation & 365 days/year \\
\hline Annual Biogas Production & $13,030,500$ SCF Year \\
\hline Biogas Specific Volume & 13.429 SCF/lb \\
\hline Biogas Density & $0.0745 \mathrm{lb} / \mathrm{SCF}$ \\
\hline Annual Biogas Production & 485 tons/year \\
\hline Methane Content & $62.3 \%$ \\
\hline Annual Methane Production & 303 tons/year \\
\hline Carbon Dioxide Content & $\mathbf{3 7 . 6 \%}$ \\
\hline Annual Carbon Dioxide Production & 182 tons/year \\
\hline Hydrogen Sulfide Content & 1,500 ppm \\
\hline Annual Hydrogen Sulfide Production & 0.94 tons/year \\
\hline Sulfur Dioxide Emission from Hydrogen Sulfide & $1.78 \mathrm{lb} / \mathrm{lb} \mathrm{H}_{2} \mathrm{~S}$ \\
\hline Annual Sulfur Dioxide Production from Hydrogen Sulfide & 1.67 tons/year \\
\hline Sulfur Dioxide Emission Rate per AP-42 & $0.60 \mathrm{lb} / \mathrm{million} \mathrm{SCF}$ \\
\hline Sulfur Dioxide Emitted Rate per AP-42 & 0.00 tons/year \\
\hline Total Sulfur Dioxide Emitted & 1.67 tons/year \\
\hline Particulate Emission Rate per AP-42 & $13.70 \mathrm{lb} /$ per million SCF \\
\hline Annual Particulate Emissions & 0.09 tons/year \\
\hline Nitrogen Oxides Emission Rate per AP-42 & $140.00 \mathrm{lb} / \mathrm{million}$ SCF \\
\hline Total Nitrogen Oxides Emissions & 0.91 tons/year \\
\hline Carbon Monoxide Emission Rate per AP-42 & $35.00 \mathrm{lb} / \mathrm{million} \mathrm{SCF}$ \\
\hline Total Carbon Monoxide Emissions & 0.23 tons/year \\
\hline
\end{tabular}

The AP-42 emission factors also provide a number for calculating sulfur dioxide emissions from natural gas. The natural gas number is added to the amount of sulfur dioxide contributed by combusting biogas containing hydrogen sulfide. It was assumed that the biogas would contain

12 Ross, C., et al. (1996). Handbook of Biogas Utilization, Second Edition. Muscle Shoals, AL: Southeastern Regional Biomass Energy Program. p. 7-10. 
$1,500 \mathrm{ppm}$ sulfur dioxide. Using dairy manure as the feedstock, this value could be as low as 480 ppm or as high as $2,000 \mathrm{ppm}$. Given the assumed sulfur dioxide content, the facility contributes 1.67 tons of sulfur dioxide to the atmosphere annually.

The second-largest amount of air emissions released by the facility are nitrogen oxides, of which 0.91 tons are discharged every year. Although this and the sulfur dioxide would fall far below the 100 tons/year threshold allowed for an attainment area under the Title V air permitting system, it is recommended that a clarification be made with an appropriate state agency on the exact nature of construction and operating permits that would be required to operate a facility such as this.

\subsubsection{Costs and Benefits Estimates}

The complete digester system consists of three components: an energy plant, a digester plant, and a solids processing plant. As already discussed, the normal efficiency of a small internal combustion engine that converts biogas into electricity is about $24.4 \%$, a heat rate of 14,000 $\mathrm{Btu} / \mathrm{kWh}$. The basic cost of this type of engine/generator, including heat recovery and controls, was estimated to be $\$ 1,050 / \mathrm{kW}$. The engine/generator is assumed to be housed in a $30 \mathrm{x} 30 \mathrm{ft}$ building. A stand-by flare should also be nearby to burn off biogas in the event something prevents it from being combusted in the engine.

As already mentioned, the digester was assumed to be a plug-flow reactor, a process developed during the 1970s. Other digestion plant subsystems include a receiving pit that has storage capacity equivalent to 2 days loading rate. Although not factored into this analysis, the digester system should also have a liquid storage tank with enough capacity to hold 6-month's worth of liquid filtrate.

The last component of the digestion system is the solids recovery plant. Each day, a fraction of the digested slurry is discharged and collected in a discharge tank, and fresh feedstock is added to the digester. The collected digestate will be sent to an on-site solids recovery building where mechanical separators divert the fiber and liquid fractions. It was assumed that the project would use a screw-press mechanical separator which is housed in a $20 \times 20 \mathrm{ft}$ building.

Although the three components of the digestion system are assumed to be "turn key" installed, digester engineering fees and a contingency rider are added to the overall capital cost assumptions. Engineering fees are assumed to be $10 \%$ of the entire plant cost. Contingency was also assumed to be $10 \%$ of the entire plant cost.

The engine and induction generator were estimated to cost $\$ 70,284$. Including the cost of the flare and other necessary engine plant subsystems, such as the building to house the engine/generator, piping, biogas meters, switchgear, and intertie components required by most electric utilities, the total capital cost for the energy plant was $\$ 109,684$. The cost of constructing the digester was estimated to be $\$ 97,825$, including the cost of the cover, as well as all gas handling and transmission costs. The cost of the screw-press separator and building was estimated to be $\$ 31,000$. Engineering costs and the contingency rider were each estimated to be $\$ 23,851$. Thus, the total capital expense was estimated to be $\$ 286,211$. The capital budgeting summary for the dairy manure plug-flow digestion system is provided in Table 3.6. 
TABLE 3.6: Plug-Flow Digester Capital Budgeting Summary Plug-Flow Digester

Energy Plant
Digester Plant
Solids Recovery Plant
Engineering Fees
Contingency
TOTAL CAPITAL COST

109,684

97,825

31,000

23,851

$\underline{23,851}$

286,211

Engine O\&M costs were estimated to be $\$ 0.0125 / \mathrm{kWh}$ of electricity generated, ${ }^{13}$ which came to a total annual expense of $\$ 5,662$ during the first year of operation. The first year expenses associated with the digester system were $\$ 9,783$, and solids recovery O\&M was $\$ 1,550$. Total expenses during the first year of the project were $\$ 16,995$.

The value of the digester was established by the amount of saleable coproducts generated. These included electric energy, thermal energy, and separated fiber. Fiber recovery from a dairy manure digester is a well-proven coproduct of considerable valuable. A number of coproducts have no assumed value in the analyses. For example, if the digestion system were large enough, carbon dioxide gas could be separated from biogas before combustion. However, in small facilities such as this one, the chance for an economic return is small and no value was assumed. Additionally, no value was assumed for reducing environmental externalities.

In determining the offset cost of purchased power, the electricity rate used was assumed to be representative of rates in New York. To help simplify analysis, electric rates were assumed to be a blend of demand and energy charges. Based on a review ${ }^{14}$ of average commercial rates for the state, this project could offset an average of about $\$ 0.113 / \mathrm{kWh}$. Given the $\mathrm{kWh}$ generated during the course of a year, this system could offset enough purchased power sufficient to save $\$ 51,187$ during the first year of operation. The value of the thermal energy recovery system was based on offsetting the delivered cost of purchased propane that was assumed to cost $\$ 0.85 / \mathrm{gal}$. This translates into a cost of about \$12.41/million Btu. Given the total amount of thermal energy produced during the course of a year, this system could provide a saving of $\$ 10,476$ in propane costs during the first year of operation. Fiber product sales were estimated to be $\$ 16,671$. Total revenue for the first year of the project summed to $\$ 78,333$.

\subsubsection{Economic Evaluation}

First year plant income on the pro forma is defined as the sum of depreciation $(\$ 30,653)$, annual revenue, and annual expenses. Because depreciation is a negative value, total system before tax

\footnotetext{
${ }^{13}$ Ross, C., et al. (1996). Handbook of Biogas Utilization, Second Edition. Muscle Shoals, AL: Southeastern Regional Biomass Energy Program. p. 7-10.

${ }^{14}$ Energy Information Administration (1998). Monthly Electric Utility Sales and Revenue Report with State Distributions (Form EIA-826) Estimated U.S. Electric Utility Average Revenue per Kilowatt-hour to Ultimate Consumers by Sector, Census Division and State. Washington, DC: U.S. Department of Energy. The table is available at: http://www.eia.doe.gov/cneaf/electricity/epm/html/table55.html.
} 
income was a positive $\$ 61,338$. Given the stated tax rate of $37.5 \%$, the first year tax liability was $\$ 11,507$. The project had a first year after tax income of $\$ 19,178$.

In every year of the project's life, this scenario yielded a positive after-tax income. Cumulative after-tax cash flow was estimated to total $\$ 626,200$. Table 3.7 provides the investment merit statistics. Given the assumptions used, the positive NPV shown indicates that the project under consideration has investment merit. As indicated in Figure 3.4, the economic sensitivity of discount rate to NPV is quite robust and remains positive throughout the range of discount rates likely to be encountered.

\begin{tabular}{|lr|}
\hline \multicolumn{2}{|c|}{ TABLE 3.7: Plug-Flow Digester Economic Summary } \\
\hline NPV & $\$ 35,852$ \\
IRR & $16.6 \%$ \\
SPP & 5.3 years \\
CCF & $\$ 626,200$ \\
Cumulative Taxes Paid & $\$ 375,720$ \\
\hline
\end{tabular}

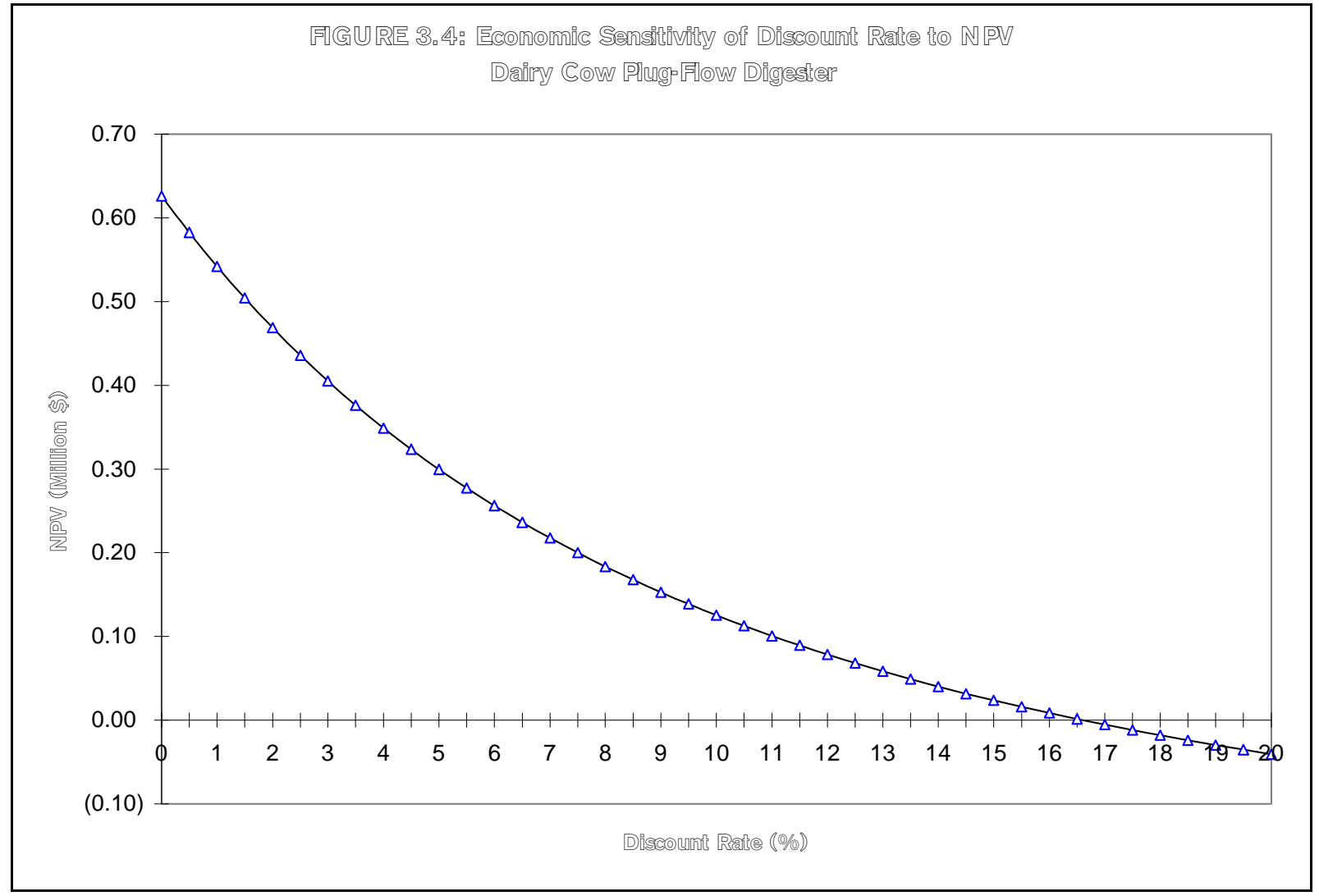

Figure 3.5 provides the economic sensitivity of project life to IRR. It is interesting because it demonstrates the project's discounted payback period. Unlike the simple payback period that measures liquidity only, this figure indicates that the true merit of the project, its profitability, is realized in about 13 years. 


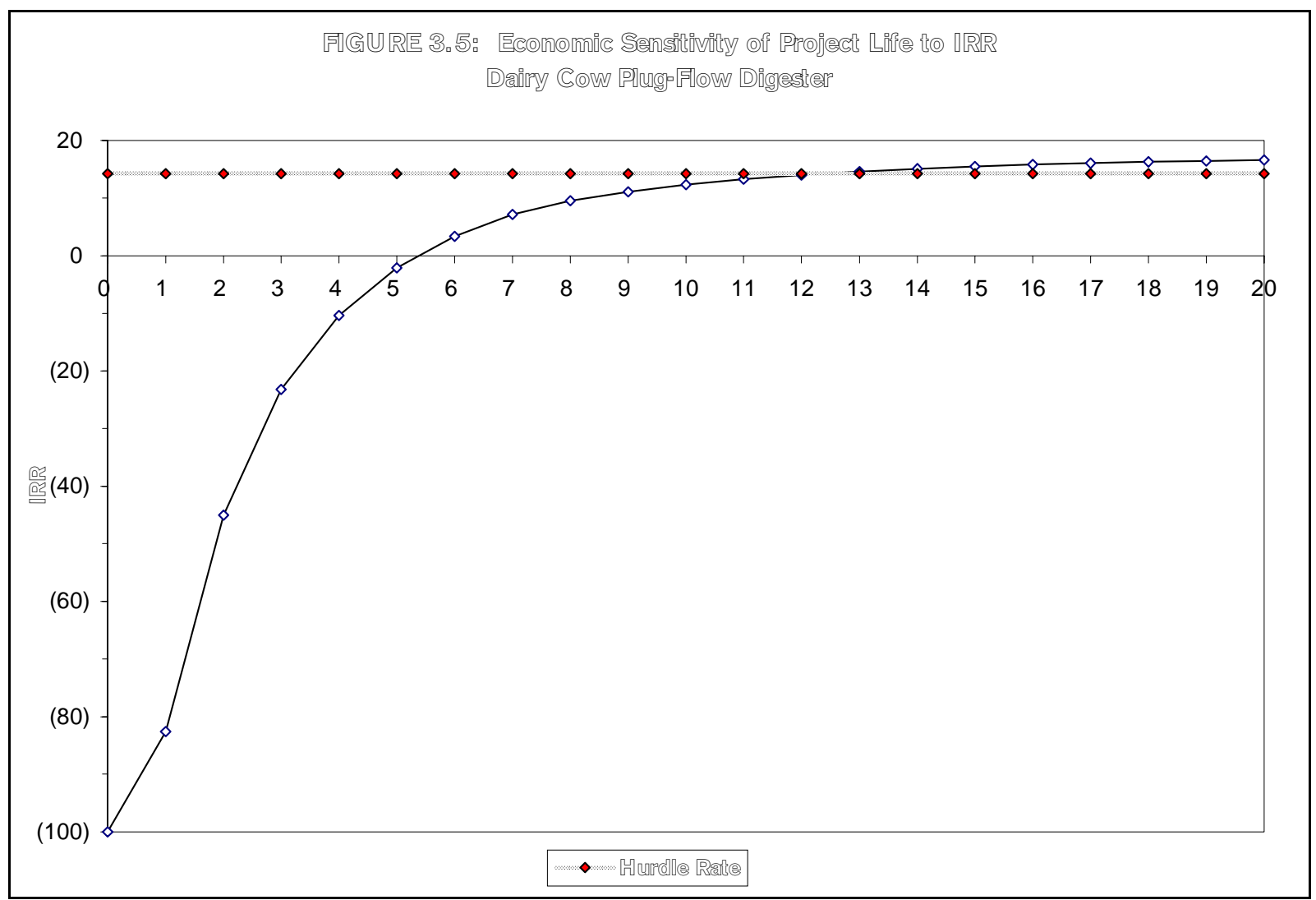

As mentioned earlier, pro forma economic evaluations of investment decisions can lead to different conclusions than pro forma evaluations of financing decisions. The base data just described are provided from the finance pro forma evaluation in Table 3.8.

\begin{tabular}{|lr|}
\hline \multicolumn{2}{|c|}{ TABLE 3.8: Plug-Flow Digester Financing Summary } \\
\hline NPV & $\$ 83,321$ \\
IRR & $34.3 \%$ \\
SPP & 2.6 years \\
CCF & $\$ 492,271$ \\
Cumulative Taxes Paid & $\$ 295,362$ \\
\hline
\end{tabular}

As shown in Figure 3.6, the financing sensitivity of discount rate to NPV is quite robust. The NPV remains positive throughout most of the range of discount rates likely to be encountered. 


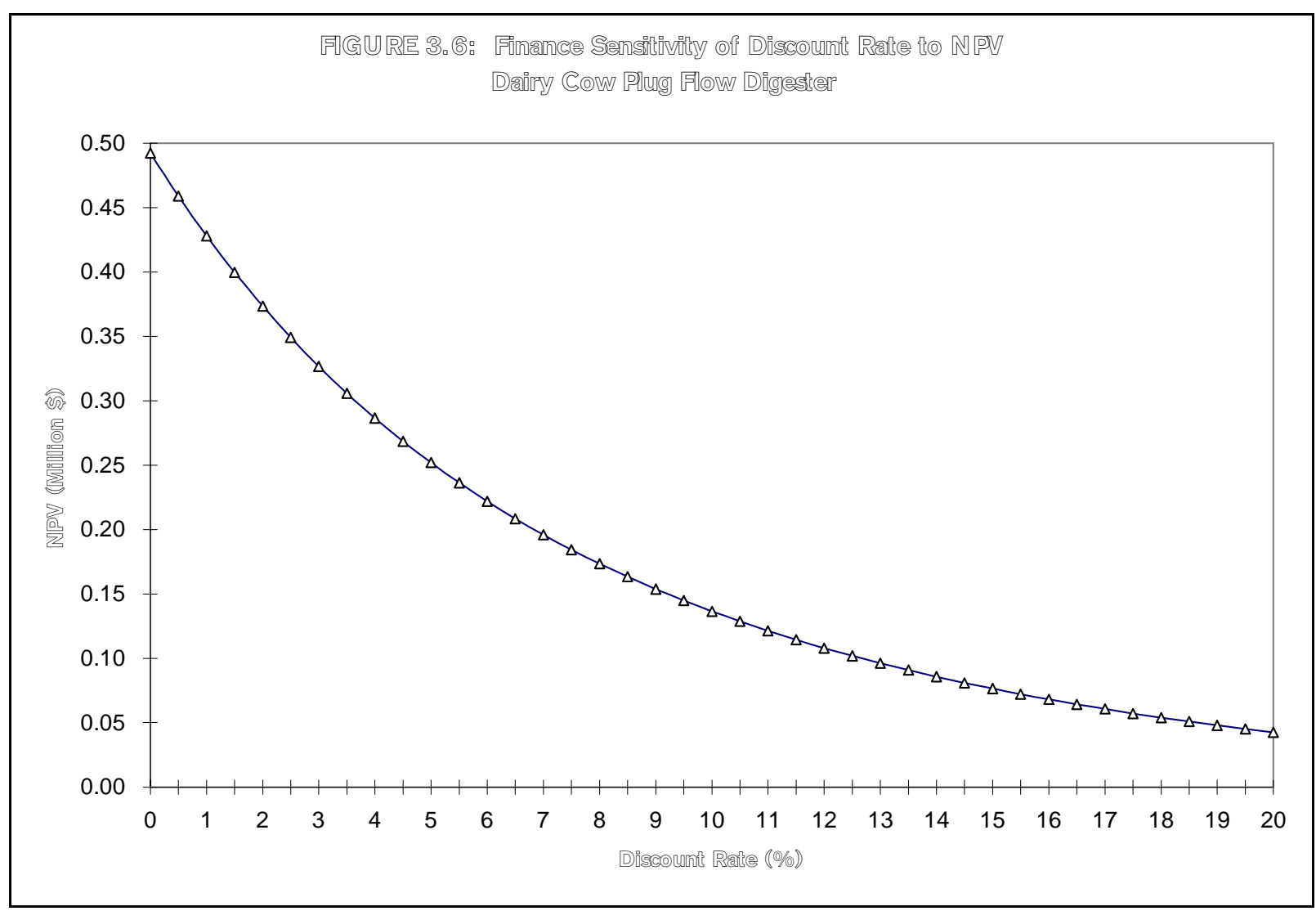

\subsection{Coproduct Utilization Illustration}

Another objective of this section is to illustrate the importance of maximizing coproduct use and other offsets made available by adopting AD technology. The data are drawn from a Western Regional Biomass Energy Program ${ }^{15}$ study. The types of digesters analyzed were covered lagoon, plug-flow, and complete-mix. Each digester type was evaluated under two specific scenarios. The first accounted for a full revenue stream, which includes savings from on-farm electricity and heat recovery offsets, surplus electricity sales, manure disposal savings, and the sale of digested solids. The second evaluated each digester technology accounting only for savings from on-farm electricity offsets and surplus electricity sales. As noted earlier, basic system data and additional macro variables were linked into $\mathrm{CashFlow}^{(}$, a model that provides a summary of primary investment merit statistics.

\subsubsection{1,000-Head California Dairy Farm with Covered Lagoon Digester}

The manure was collected for this digester by a periodically scraping the apron and feedlane and flushing the milking parlor daily with water. It was assumed that the manure removed from the parlor and feedlane accounted for about $55 \%$ of the manure produced on the farm. The digested solids and liquids were assumed to have no monetary value, even though the liquids can be land applied with irrigation guns. The value of the 1,000-head California covered lagoon digester was

15 Whittier, J., et. al (1993). Energy Conversion of Animal Manures: Feasibility Analysis for Thirteen Western States. Golden, CO: Western Regional Biomass Energy Program. 
derived from the measure of offsets in currently purchased electricity and from the recovery of heat from the engine/generator that was used to warm dairy sanitary wash water. The digester was assumed to have an average production capacity of $81-\mathrm{kW}$ and to have annually produced $504,111 \mathrm{kWh}$. Purchased electricity costs had a demand charge of about $\$ 5.00 / \mathrm{kW}$, with an energy charge of $\$ 0.05 / \mathrm{kWh}$. Available waste heat was used as an offset for purchased propane costing \$0.75/gal, with 2,800 Btu recovered for every $\mathrm{kWh}$ generated.

Table 3.9 provides the investment merit statistics for this project. As mentioned earlier, a positive NPV indicates that a project is cost-effective. Evaluation of the NPV data in Table 3.9 reveals that a covered lagoon digester has investment merit when both electricity and recovered heat can be used as creditable offsets in the analysis. But if, for example, the waste heat recovered from the engine/generator were to be used for heating the digester during the winter in cooler climates to balance daily biogas production, the covered lagoon digester would no longer be cost-effective.

\begin{tabular}{|l|c|c|}
\hline \multicolumn{3}{|c|}{ TABLE 3.9: 1,000 Head California Dairy Farm with Covered Lagoon Digester } \\
\hline \multirow{3}{*}{ NPV } & Full Income & Electricity Only \\
\cline { 2 - 3 } IRR & $\$ 36,075$ & $(\$ 23,476)$ \\
SPP & $11.8 \%$ & $6.2 \%$ \\
CCF & 6.2 years & 8.3 years \\
\hline
\end{tabular}

\subsubsection{0-Head South Dakota Dairy Farm with Plug-Flow Digester}

The manure was collected for this digester by scraping the apron and feedlane daily. It was assumed that $100 \%$ of the manure was collected and placed into the digester after it was diluted with enough water to produce the desired TS concentration. The value of the 300-head South Dakota plug-flow digester was derived, in part, from a change in manure management. It was assumed that the facility formerly used a hauling company to remove the manure from the farm at an annual cost of $\$ 2.00 / \mathrm{cow}$. This assumption means that the former expenses associated with manure disposal were converted into revenue for the farm operator. It was also assumed that the digested solids were used as a soil amendment with a value of $\$ 2,000$ annually. The farm received offsets from currently purchased electricity and from the engine/generator's recovered heat used for dairy sanitary wash water. The digester was assumed to have an average production capacity of $35-\mathrm{kW}$, and annually produced $216,047 \mathrm{kWh}$. Purchased electricity costs had an energy-only charge of $\$ 0.075 / \mathrm{kWh}$. The digester produced more electricity than was consumed on the farm, and the surplus was sold at $\$ 0.05 / \mathrm{kWh}$. Available waste heat was used as an offset for purchased propane costing $\$ 0.75 / \mathrm{gal}$, with 2,800 Btu recovered for every $\mathrm{kWh}$ generated.

Table 3.10 provides the investment merit statistics for this example. As mentioned earlier, a positive NPV indicates that a project is cost-effective. Evaluation of the NPV data in Table 3.10 reveals that a plug-flow digester has investment merit when all of the energy and recoverable coproducts can be used as creditable offsets in the analysis. But if, for example, the manure disposal savings and digested solids recovered were not creditable, and the waste heat from the engine/generator was not recovered and was instead used to heat the digester during the winter, the plug-flow digester is no longer cost-effective. 


\section{TABLE 3.10: 300-Head South Dakota Diary Farm with Plug-Flow Digester}

\begin{tabular}{|l|c|c|}
\hline & Full Income & Electricity Only \\
\cline { 2 - 3 } NPV (\$) & $\$ 18,124$ & $\mathbf{\$ 4 4 , 6 4 6 )}$ \\
IRR (\%) & $10.8 \%$ & $1.7 \%$ \\
SPP (years) & 6.4 years & 12.5 years \\
CCF $(\$)$ & $\$ 130,331$ & $\$ 16,949$ \\
\hline
\end{tabular}

\subsubsection{0,000-Head Nebraska Swine Farm with Complete-Mix Digester}

It was assumed the complete-mix digester was located on a farrow-to-finish farm using underfloor scrapers to move the manure from the production parlors to a holding pit. It was also assumed that $100 \%$ of the manure was collected and placed into the digester. The value of the 10,000-head Nebraska complete-mix digester was derived from the offsets that the farm received from currently purchased electricity and from engine/generator's recovered heat used for parlor heating. The digester had an average production capacity of $101-\mathrm{kW}$, and annually produced $624,137 \mathrm{kWh}$. Purchased electricity costs had an energy-only charge of $\$ 0.067 / \mathrm{kWh}$. The digester produced more electricity than was consumed on the farm, and the surplus was sold at $\$ 0.04 / \mathrm{kWh}$. Available waste heat was used as an offset for purchased propane costing $\$ 0.75 / \mathrm{gal}$, with 2,800 Btu recovered for every $\mathrm{kWh}$ generated.

Table 3.11 provides the investment merit statistics for this example. Once again, a positive NPV indicates that a project is cost-effective. Evaluation of the NPV data in Table 3.11 reveals that a complete-mix digester has investment merit when all of the energy and recoverable coproducts can be used as creditable offsets in the analysis. But if, for example, the heat was recovered from the engine/generator were to be used for heating the digester during the winter in cooler climates, the complete-mix digester would be no longer cost-effective.

\begin{tabular}{|l|c|c|}
\hline \multicolumn{3}{|c|}{ TABLE 3.11: 10,000-Head Nebraska Swine Farm with Complete-Mix Digester } \\
\hline \multirow{3}{*}{ NPV } & Full Income & Electricity Only \\
\cline { 2 - 3 } IRR & $\$ 4,146$ & $(\$ 29,297)$ \\
SPP & $8.8 \%$ & $6.5 \%$ \\
CCF & 7.8 years & 9.4 years \\
\hline
\end{tabular}

\subsection{Other Economic Considerations}

Economic benefits may also accrue to a third party such as an electric utility. Cost-effective distributed resource (DR) technologies equivalent to farm-based $\mathrm{AD}$ systems can reduce infrastructure investment and increase the asset use of an electric utility transmission and distribution (T\&D) system. They also offer the opportunity to provide enhanced levels of power quality and reliability, tailored energy services, and retail service offerings to the customer. The direct benefits to a T\&D system include grid support (reduced line losses, voltage support, and power conditioning benefits), deferral of upgrades to substations, and provision of power in increments matching projected demand patterns. 
The DR benefit that may accrue to an electric utility is site specific. Criteria useful to help define candidate substations or feeders that may benefit from DR technology address issues associated with load growth and the need for capital expenditures greater than $\$ 200,000$ within a 3-5 year period. Rarely is any credit provided for the DR benefits of farm-based AD systems usually sited at the "end of the dirt road." The power conditioning benefits, as well as the possibility of allowing electric utilities to defer upgrading rural T\&D systems, can make a significant, yet hard to quantify, impact. However, examples estimated in the DR literature range from $\$ 100 / \mathrm{kW} / \mathrm{year}$ to as high as $\$ 800 / \mathrm{kW} /$ year $^{16}$ when the value of generation capacity, energy production, deferred T\&D construction, transformer loss reduction, and line loss reduction are fully counted.

In the era of deregulation, an electric utility could use AD technologies as an innovative business opportunity. These could include helping clients (in and out of its service territory) develop projects. These clients frequently require technical and financial services that a utility could readily provide either directly or through a contracting relationship. These types of services are also billable and provide revenue-generating opportunities.

For example, a major electric utility recently teamed with another corporation to provide energy conversion systems that use a proprietary AD process for manufacturing biogas and other coproducts. This team now provides full scope engineer-procure-construct projects, as well as O\&M training and management programs for energy conversion facilities. It can provide all planning, engineering, design, materials and equipment procurement, site preparation, construction, construction management and coordination, equipment installation, and startup and testing necessary to deliver a fully operational energy conversion facility. Primary components may include simple cycle or combined cycle gas turbine equipment to generate electricity and process steam, or a gas-fired boiler configuration, where there is a large process steam demand. The team also provides all planning, engineering, design, materials and equipment procurement, site preparation, construction, construction management and coordination, equipment installation, and startup and testing necessary to deliver a fully operational transmission line and connecting switchyard to the local power grid.

Another service could be in the area of providing contracts that provide equipment maintenance and service needs to customers who do not have the time, desire, or ability to conduct routine or emergency services on their equipment. One last service area, financing in the form of leases and rents for key equipment such as generators, engines, and gas handling equipment, does have some potential.

\subsection{Climate Challenge}

The Climate Challenge program is a joint initiative of the DOE and the electric utility industry to reduce greenhouse gas emissions. The program was established as part of the U.S. response to the 1992 Rio Treaty for the international stabilization of greenhouse gases. One of the reasons for joining Climate Challenge is that effective voluntary efforts today may negate the need for mandatory legislation or regulations tomorrow, so the program is often presented as

\footnotetext{
${ }^{16}$ Whittier, J.; Haase, S.; Badger, P. (1997). "Distributed Generation from Biomass Resources: Emerging Potential for Utilities." Proceedings of Bioenergy '96; September 15-20, 1996; Nashville, Tennessee. Muscle Shoals, AL: Southeastern Regional Biomass Energy Program; pp. 598-604.
} 
being a form of "risk insurance." The basis of the program is a 1994 MOU between DOE and the Edison Electric Institute, American Public Power Association, National Rural Electric Cooperative Association, Large Public Power Council, and Tennessee Valley Authority.

The program consists of commitments by electric utilities to undertake actions to reduce, avoid, or sequester greenhouse gas emissions. These commitments are formalized in individual utility participation accords for large utilities and through letters of participation for utilities having less than 50,000 customers. DOE provides technical information and support, reports on the progress of the program, and provides public recognition to utility participants.

By early 1997, the accords signed and recognized now bring the number of Climate Challenge agreements to 117. The 117 agreements are on behalf of 633 individual electric utilities, which represent more than $69 \%$ of either total electric generation or greenhouse gas emissions from the U.S. electric utility industry. ${ }^{17}$ These utilities have committed to reduce, avoid, or sequester more than 45 million tonnes of carbon equivalent by the year 2000 .

Utilities that are Climate Challenge participants report their greenhouse gas emissions annually on forms developed in accordance with the guidelines established under Section 1605(b) of the Energy Policy Act of 1992 and implemented by DOE. The guidelines explain the reporting process and other program details, and all carbon equivalent emission reductions are credited against any future mandatory requirements. In addition to reporting greenhouse gas emissions data, utility participants submit an annual report to DOE describing their actions and achievements under their individual participation accords.

As part of the Climate Challenge process, the electric utility industry and DOE jointly developed the Climate Challenge Options Workbook, which describes more than 50 options that utilities can use to meet their commitments. The options range from generating plant efficiency improvements to forest management projects. Other options include participation in DOE Energy Partnership programs affecting energy end-use and supply. Utilities are also encouraged to consider a host of voluntary programs, including AgSTAR.

As of 1996, several utilities had expressed a desire to implement a broad range of methane reduction initiatives that include coal mines, landfill gas, and other methane control programs. Two projects reported by one utility in Pennsylvania claimed reductions in methane emissions from livestock manure. ${ }^{18}$ As will be detailed in Section 5.1, 3,000-4,000 dairy, swine, and poultry farms in the United States are large enough to economically justify an AD system. Participation in the Climate Challenge program can benefit an electric utility.

Other benefits that might accrue to an electric utility include customer retention, customer service, and local area job retention. Given the fluidity involved in siting agricultural facilities, an

\footnotetext{
${ }^{17}$ U.S. Department of Energy. (1997). Electric Utilities Sign Up For Greenhouse Gas Reduction Program. 19 March press release, Washington, DC.

${ }^{18}$ Southeast Regional Biomass Energy Program (1997). "Global Warming Review”. July 1997 Update. Muscle Shoals, AL: Southeast Regional Biomass Energy Program.
} 
electricity supplier might find these more advantageous in the long run than concerns over shortterm issues such as revenue erosion. Providing technology that supports a sustainable livestock industry also provides the servicing utility with productive large-scale energy customers at feed and packing plants that can require more than $70 \%$ of the electrical energy required in the total life-cycle of pork production.

\subsection{Economic Evaluation Summary}

Two guides were constructed to assess the economic benefit of anaerobic digesters. The first was a covered anaerobic lagoon digester operating on a swine farm in North Carolina, the second was a plug-flow digester operating on a dairy farm in New York. Life-cycle savings were estimated, with sensitivities considered for investment risk. A word of caution is in order--the evaluations presented here should be used to provide a rough estimation only.

Nevertheless, these evaluations offer the following major conclusion. Having a full range of creditable coproducts that can be used as revenues in a pro forma analysis can make a significant difference in whether a project has investment merit for the user. Quite simply, it is very difficult to justify the investment in an anaerobic digester based only on the revenue received for offsetting currently purchased electricity and the sales of surplus electricity. The profitable operation is one that maximizes use of all coproducts, especially engine/generator waste heat that can be recovered for productive on-farm uses. Other direct economic returns can be had from the use of digested solids and liquids.

Finally, economics is too often criticized for "knowing the price of everything and the value of nothing." The analyses presented here do not provide a quantifiable price impact for some of the more subjective value advantages that can result from the adoption of farm-based AD technology. For example, no value was calculated for environmental externalities. Unrecovered methane in biogas produced by the inevitable decomposition of animal manures is a suspected agent of global climate change. Biogas can be converted into carbon dioxide through combustion by an engine/generator. A second unquantified externality is the ability of anaerobic digesters to help control odors and flies. With urban encroachment into rural areas, many farms today use a digester specifically installed for odor control. Probably the best example of this is a farm in Lancaster, Pennsylvania. When faced with urban encroachment near the farm, the owner initiated his digestion project because of his desire to proactively reduce the risk of odor complaints from the new neighbors.

Other on-farm impacts are difficult to value. The installation of an anaerobic digester often reduces the direct labor requirements associated with daily manure management and especially the sometimes frequent need for holding pit pump-outs or the cleaning of clogged irrigation guns. Additional value can also be derived from reduction in the need to purchase fertilizers and soil conditioners. Just as many farmers do not charge for the value of their labor, many farmers also do not fully offset the cost reductions associated with using digested liquid nutrients or tilthbuilding solids. 


\subsection{CASE STUDIES OF ANAEROBIC DIGESTION PROJECTS}

To provide a reality base to the economic evaluations presented in the previous section, a number of operating and non-operating AD systems were surveyed using site visits and literature review. Some of the digester systems visited are outlined below as case studies to provide information on actual project and maintenance histories as well as the operator's "lessons learned". The case studies are presented in chronological order by their operational date.

Figure 4.1 provides a numerical status report of farm-based anaerobic digesters in the United States. The data presented include the digesters that are installed on working dairy, poultry, and swine farms. It excludes 65-70 digesters that are installed on beef farms and digesters that are university research-oriented. These data also do not count 17 digesters that were shut down when the farms they were on were sold or quit livestock production.

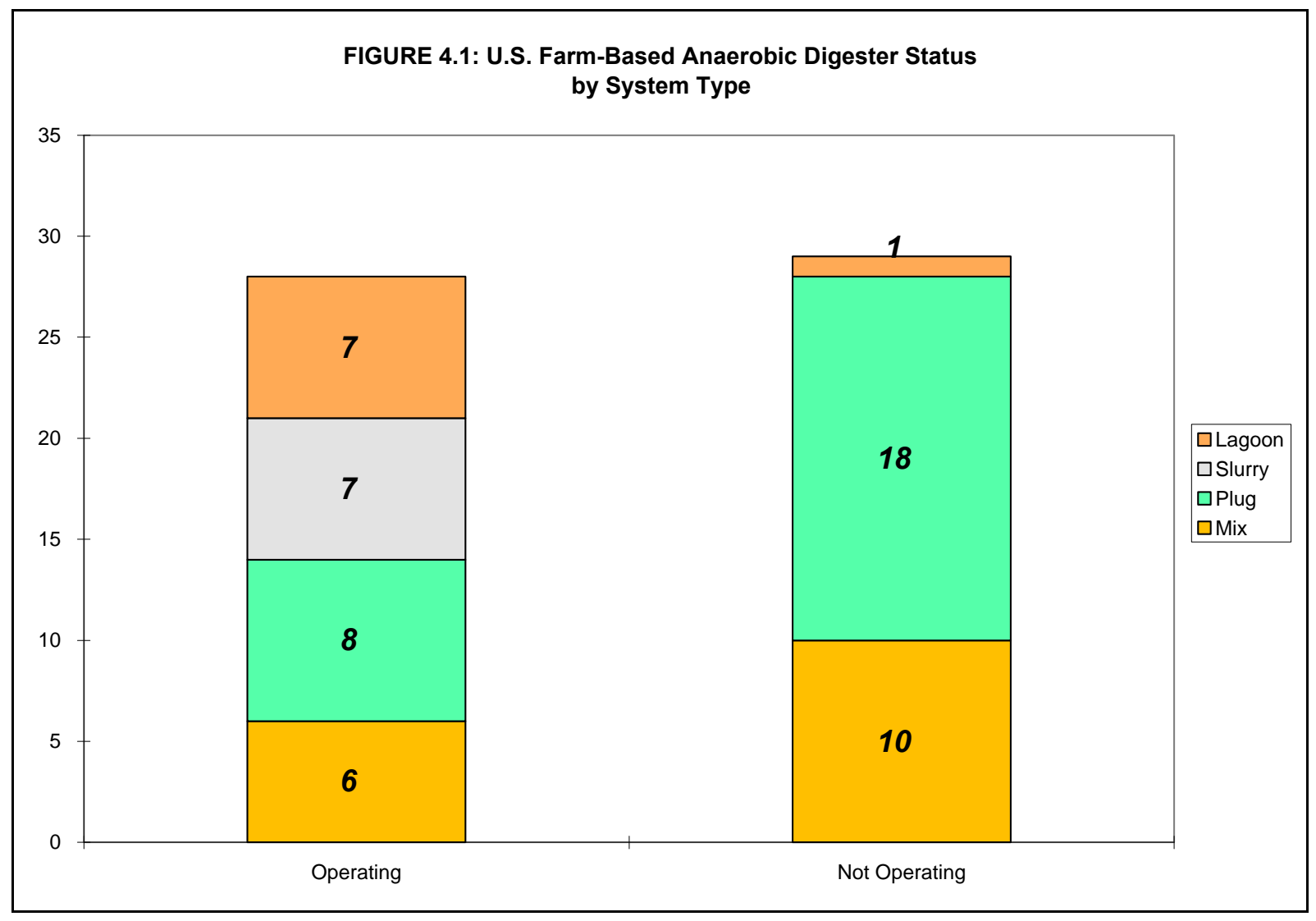

0

The numerical status is not the whole story. Surveyed farmers who have installed and continue to operate digesters are generally satisfied with their investment decisions. Most chose to install digesters for non-economic reasons, primarily to control odor or contain excess nutrient runoff.

Farmers have found that the returns provided from electricity and other coproduct sales from the digester, however limited, are preferable to the sunk-cost of conventional disposal providing zero return on investment. Moreover, without the environmental benefits provided by AD technology, 
some might have been forced out of livestock production. AD is sometimes the only technology that allows growth in the livestock production business. Turning a waste liability into a profit center that generates annual revenues can moderate the impacts of declining commodity prices and diversify farm income.

None of the farmers surveyed with operating anaerobic digesters said that they regret their basic decisions. Most would have preferred to spend less money on design and installation, but they are unsure of exactly how costs could have been cut. Many seek new ways to increase profitability by the sales of coproducts, primarily the digested solids. They would like additional assistance in determining how best to optimize the value-added coproducts. Beating the odds, a few have met the challenge of making their systems work despite bad design or equipment. The hard knock of practical experience makes them the true superstars of farm-based AD technology in the United States.

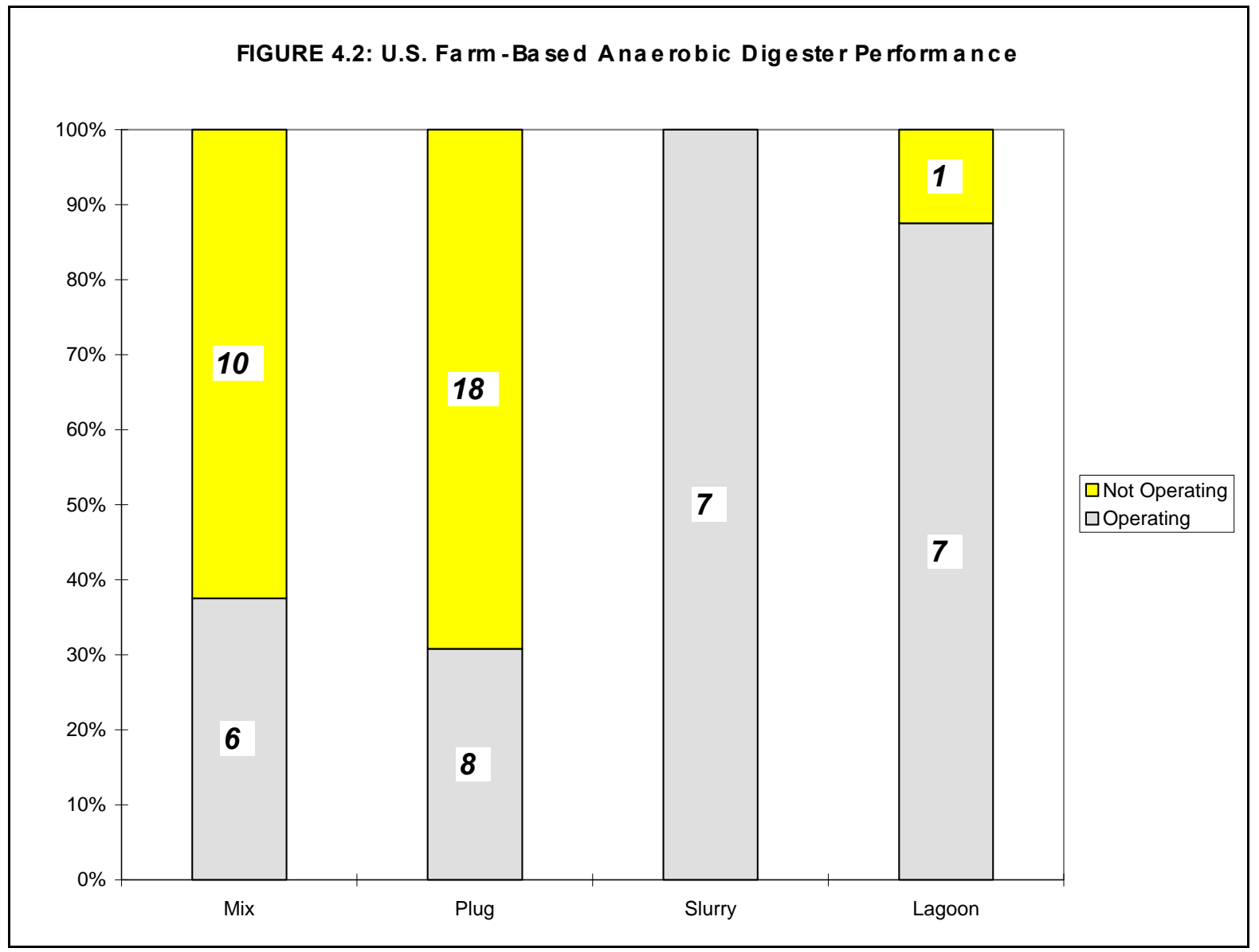

Still, at face-value, the performance data in Figure 4.2 are not encouraging to a farmer considering whether to install an anaerobic digester as a manure treatment option. Overall, the chance for failure, i.e., having a non-operating anaerobic digester, is about $50 \%$ in the United States. However, given the fairly dismal track records of deploying other energy technologies, ranging from synthetic fuels to other renewables, this level of performance is probably no better or worse than others that received government support during the energy crises of the 1970s. 
Among the types of farm-based digesters actually built, the failure rate for complete-mix and plugflow technologies are staggering; $71 \%$ and $63 \%$, respectively. For covered lagoon digesters, the failure rate is around $12 \%$. Because there are fewer operating slurry digesters, their current $100 \%$ success rate is certainly inconclusive. Once slurry digesters have a larger market share, the opportunity for system failures caused by poor design, fabrication, and operation will be more equal to that of the other technologies, and the slurry's performance can then be gauged.

One encouraging note is that reliability of the digesters constructed since 1984 is far better than that of those constructed during the period 1972-1984. This is generally due to a more simplified digester design. Even more encouraging is the resurgence of interest in farm-based AD technology. For example, in the past 4 years (1994-1998) 11 new systems were installed. Another 10 systems are currently under construction or in a design phase.

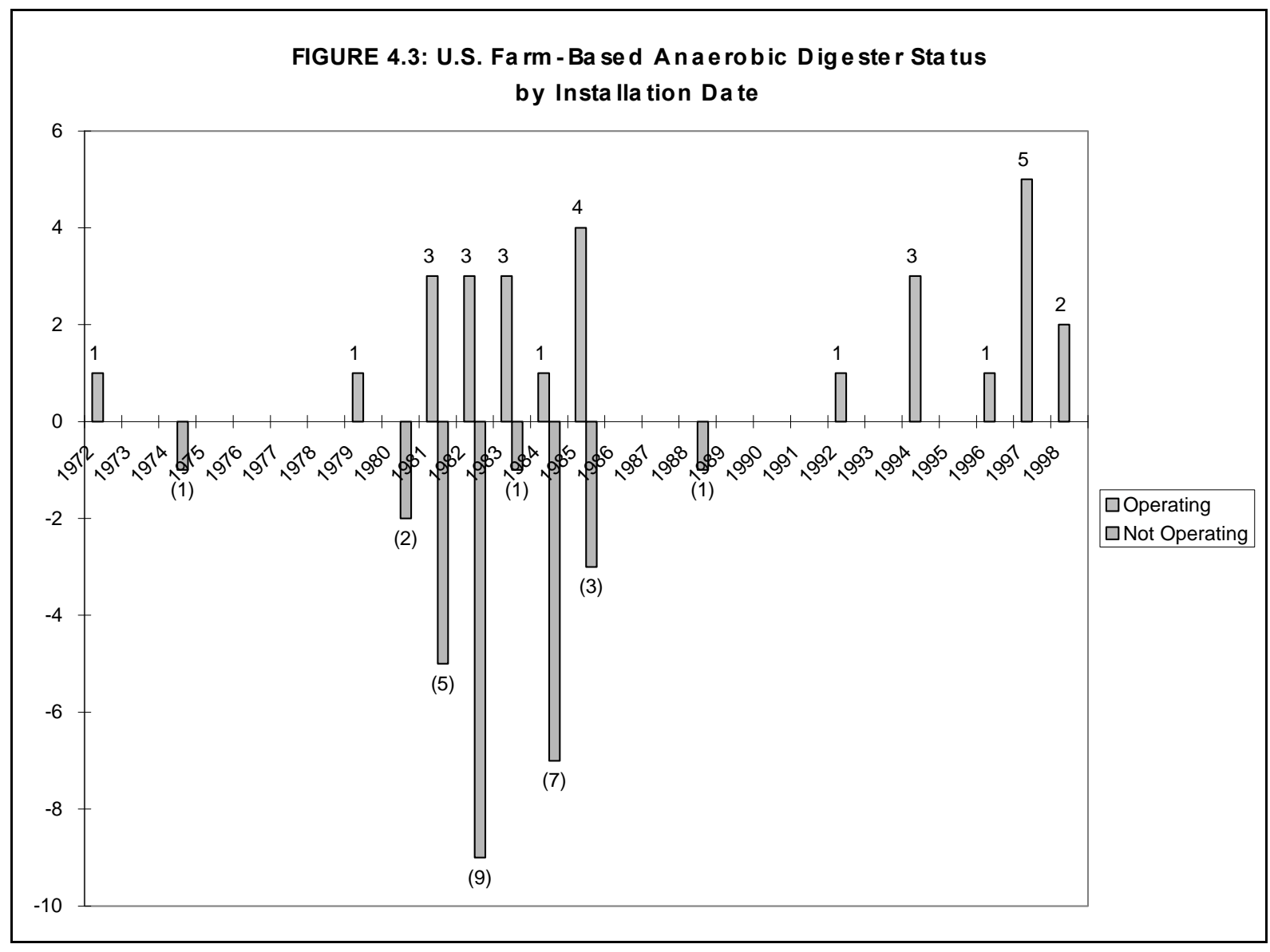

A project now under construction near Bellingham, Washington, ${ }^{1}$ is using technology licensed from Germany. The modular digester will be fed the manure from 1,500 dairy cows, and is designed to be slightly oversized to retire the anaerobic lagoon now used. The saleable commodities are scheduled to be a liquid organic nutrient and electricity. One interesting point about this operation is

\footnotetext{
${ }^{1}$ Thomas, M. (6 August 1998). Personal communication. Safe Environmental Inventions, Inc., Bellingham, WA.
} 
that the system comes with a performance bond equal to the full value of the facility. The performance bond is the first of its kind issued in the United States. It is combined with a performance warranty that guarantees all commodity outputs as stated in the design analysis for a 5year extendable period, effective immediately at system startup. Startup of this digester is expected in spring 1999.

There is also some movement toward the development of centralized AD projects. Centralized systems might also be considered in areas where dairy, swine or poultry farms are too small to support a cost-effective on-farm facility.

In Tillamook, Oregon, an agreement was recently signed to build a long-discussed centralized facility using the manure from 10,000 cows. The facility would process about 500 tons of dairy manure and other organic waste each day. Because of low prices in the local electrical energy market, plans call for the biogas to fuel one or more boilers to produce steam that could be marketed to local industries. The planned facility will also produce 27,000 cubic yards $\left(\mathrm{yd}^{3}\right)$ of fiber/year and 70,000-80,000 gal of liquid nutrients daily. The combined capital cost is estimated to be about $\$ 12$ million. The item of interest here is that the farmer's have formed a manure supply cooperative (MEADCO) that represents the interests of its members in ensuring a consistent supply of quality manure to the project. MEADCO will manage individual supply contracts with its members and coordinate the transportation of manure and liquid nutrients between its members and the conversion plant. Construction of this centralized plant is expected to commence in 1998.

Combined with the Oregon project, the DOE's Commercialization Ventures Program announced ${ }^{1}$ that it will provide $\$ 1.5$ million to BioRecycling Technologies Inc. (BTI) to demonstrate a zero discharge process to convert the manure from 10,000 cows into energy, fertilizers and potting soil. This facility in California is scheduled to begin operation in late 1998, and is discussed in greater detail in Case Study 4-23.

${ }^{1}$ U.S. Department of Energy (1996). Emerging Renewable Energy Technologies Given Commercial Boost. 12 November press release, Washington, DC. 
Case Study 4.1: $\quad$ McCabe Farms

\begin{tabular}{lll|}
\hline CONTACTS & Rich McCabe & Mrs. Harold McCabe \\
\hline Address: & Route 1, Box 3 & 205 S. Cherry Street \\
& Mt. Pleasant, IA 52641 & Mt. Pleasant, IA 52641 \\
Telephone: & 319.385 .2139 & 319.986 .5806
\end{tabular}

GENERAL SYSTEM INFORMATION

Farm Type: Swine (farrow-to-finish).

Herd Size: $\quad 1,150$ total head with 150 sows.

System Type: $\quad$ Buried concrete slurry tank with no mechanical mixing.

Dimensions: $\quad 17 \mathrm{ft}$ by $30 \mathrm{ft}$ diameter.

Capacity: $\quad 7,400 \mathrm{ft}^{3}(55,000$ gal $)$.

Biogas Production: Never metered.

Operational Date: 1972.

1998 Status: $\quad$ Operational.

Project History: $\quad$ Harold McCabe built the first farm-based digester in the United States in response to urban spread. Most of the once-rural farm's hog production facilities were built between 1951 and 1953. By 1970, the Town of Mt. Pleasant had expanded to the border of McCabe Farms, and it became necessary to develop an odor-free system of managing swine manure. Mr. McCabe adapted technology from a municipal wastewater treatment facility, and the partially buried digester reactor is an insulated, epoxy-lined concrete stave-ribbed silo with a coneshaped bottom. As needed, about 4,000 gal/d of water are used to flush the farrowing, nursery, and finishing rooms using shallow, continuous-flow gutters. There is no manure pumping; all manure is moved by gravity through the entire system to the final discharge at a storage lagoon. Digester temperature is maintained using water that is heated to $90^{\circ}-95^{\circ} \mathrm{F}$ in an adjacent boiler. The water is circulated with a heat exchanger assembly suspended in the digester. Because the gas demand of the boiler exceeds the biogas production rate of the digester, the system uses natural gas for maintaining digester temperature. All the biogas is flared because there is no storage 
Maintenance History: Daily maintenance takes 5-10 minutes. The procedure involves checking the effluent input and discharge pipes to make sure they are not plugged, and checking to make sure biogas is being flared. Ten years ago, the digester was cleaned to remove built-up solids. The original cast iron input, discharge, and access port pipes were replaced with PVC, because the iron had degraded from scoring at the water level in the digester. Because convective currents produced by the heat exchanger produce enough agitation in the digester to avoid crusting problems, the rotary compressor system is no longer being used. Two additional backup systems--a mechanical agitation system for breaking up severe crusting and an auger extractor to be used in case the slurry becomes gelatinous--have never been needed. Overall, the system has experienced few problems. The only concern is that the amount of biogas produced must be balanced with the digester water flow rate.

Lessons Learned: $\quad$ On-farm AD works and effectively controls odors. The disposal of sludge produced as a result of the digestion process does not require taking land out of cultivation. The biogas produced can be a valuable product, but only those who are willing to commit to consistent monitoring should build a digester.

COSTING INFORMATION

Siting Cost: Included in capital cost.

Capital Cost: $\quad \$ 20,000$ for materials, plus labor. About 2 years were spent in selfeducation, locating equipment, and construction.

Annual O\&M Cost: $\quad \$ 2,500$ for natural gas.

End-Use of Biogas: $\quad$ Flared.

Prime Mover Type: $\quad$ Not applicable.

ANNUAL SAVINGS

Electricity Production: Not applicable.

Electricity Savings: Not applicable.

Thermal Production: Not applicable. 
Thermal Savings: $\quad$ Not applicable.

End-Uses of Effluent: $\quad$ Twice a year, before corn planting in the spring and before freezing in the fall, about 9,000 gal of effluent and sludge are removed from the digester and land applied. Because $60 \%$ of the solids in the swine manure are digested, the storage lagoon has not been cleaned out since the digester was installed 25 years ago. The remaining solids consist primarily of lignin, which acts as a soil tilth and conditioning agent. This easily handled solid material is pure and odor free.

Other System Savings: $\quad$ Odor and pollution control. "I'm still in hogs."

Designer/Installer: Harold McCabe. 
Case Study 4.2: $\quad$ Not Publicly Identified

GENERAL SYSTEM INFORMATION

Farm Type: Dairy.

Herd Size: $\quad 3,900$ total head with manure from 2,200 milkers used.

System Types: $\quad 2$ plug-flow and 2 slurry-based loop.

Dimensions: $\quad$ Plug 1: $92 \mathrm{ft}$ x $14 \mathrm{ft}$ x $20 \mathrm{ft}$ with a "V" bottom.

Plug 2: $92 \mathrm{ft} \times 14 \mathrm{ft} \times 24 \mathrm{ft}$ with a flat bottom.

Loop 1: $14 \mathrm{ft}$ x $68 \mathrm{ft}$ diameter.

Capacity:

Plug 1: $25,760 \mathrm{ft}^{3}(192,000 \mathrm{gal})$.

Plug 2: $30,912 \mathrm{ft}^{3}(231,000 \mathrm{gal})$.

Loop 1: 50,800 $\mathrm{ft}^{3}$ (380,000 gal).

Biogas Production: $\quad 34,960 \mathrm{ft}^{3} / \mathrm{d}_{\text {estimated }}^{1}$ for Plug 1 . Operator estimates production is $85 \mathrm{ft}^{3} /$ cow/d, suggesting that production is $190,000 \mathrm{ft}^{3} / \mathrm{d}$ or more.

Operational Date: $\quad$ Plug 1: 1979.

Plug 2: 1981.

Loop 1: 1985.

Loop 2: 1998 (in planning).

1998 Status: $\quad$ Operational.

Project History: $\quad$ The farm's first liquid manure handling system was built in 1961. After installation, methane bubbles forming on the surface triggered an interest in biogas production. The first digester unit was installed as a response to the energy crises of the 1970s; the purpose was to make the farm energy self-sufficient. Plug 1 processed the manure from a 600-cow milking herd and worked with an 8\%-10\% TS concentration. A chopper pump was installed to reduce crusting. As herd size increased, the second unit was built incorporating the "lessons learned," including a flat bottom unit design rather than the traditional "V" bottom. Both units exhibited a common problem associated with the plug-flow approach: solids crusting and lower system performance during the winter because of freezing. The third digester design, the loop approach, was implemented as the herd size again increased in the mid-1980s. The simplified loop digester design comparatively reduced construction costs by $\$ 40,000$. Although changes in farm manure management practices are likely contributing factors, the loop digester helped to eliminate the solids 
Maintenance History: Daily maintenance is a 15-minute check of engine oil and a walkthrough inspection. Engine oil is changed regularly every 400 hours because there is no scrubbing system to remove hydrogen sulfides from the biogas. Engine oil is monitored for signs of engine failure. Engines are overhauled as necessary, especially engine valve guides. There is an annual manual clean-out of Plug 1 to remove lime and gritty solids.

Lessons Learned:

The decision would be to go straight to a loop digester design because of reduced capital and O\&M costs. The loop digester has less outside surface area than a plug-flow digester, so parasitic heating requirements are minimized. Also, the loop digester has heat pipes installed on a center wall, so the convective currents are greater than those in a plug-flow digester. As a result, there is no need to agitate the loop digester, and the crusting problem associated with the plug-flow digester is reduced.

COSTING INFORMATION

Siting Cost:

Capital Cost:

Annual O\&M Cost:

End-Use of Biogas:

Prime Mover Type:

\section{Not available.}

$\$ 180,000$ for the first plug-flow system installed in $1979^{1}$. Modifications to the engine/generator and effluent handling system cost an additional $\$ 80,000$. Operator estimates the turnkey capital cost required to build a new loop system that would replace the 3 units installed as of 1995 would be $\$ 250,000$.

Not available.

Electricity with thermal reclaim used for heating digester and a nearby home.

Original was a Detroit Diesel system that was replaced after 5,500 hours of operation with 2 150-kW model 342 Caterpillar LP gas engine/generators. These engines operate with gold-tipped spark plugs. The engine ignition is advanced by 21 degrees, and the engines have modified carburetors to account for the lower energy content of biogas. Two additional Caterpillar engines are installed. Total biogas installed capacity has a combined rating of $600-\mathrm{kW}$. There is also a $150-\mathrm{kW}$ diesel engine/generator on standby. 
ANNUAL SAVINGS

Electricity Production:

Electricity Savings:

Thermal Production: Not available.

Thermal Savings:

End-Uses of Effluent:

Other System Savings:

Designer/Installer:

Plug 2 and Loops 1\&2: $\$ 0.025 / \mathrm{kWh}$.

Not available.
Estimated in 1995 to be 1.5-1.7 million $\mathrm{kWh}$. With the estimated biogas production, could be as high as 2.5-2.7 million $\mathrm{kWh}$.

Previously estimated $^{1}$ at $\$ 68,000$. Estimated in 1995 to be $\$ 92,000$, including sale of excess electricity generated. The 1998 energy charge is $\$ 0.09 / \mathrm{kWh}$, with no demand charge. Depending on the time of year, the average buy-back rate is between $\$ 0.02$ -

Liquids are applied to croplands with a center pivot irrigation system, which avoids the possibility of soil compaction. Digested solids are sold in bulk to local nurseries.

Use of digester greatly reduces fly and odor problems. The system eases manure clean-up and reduces labor expenses. The digestion process adds to the solids value by killing weed seeds and increasing the plant nitrogen availability of the liquids used for land application.

Energy Harvest, Inc. (Plug 1).

Farm designed and installed.

1. Ashworth, J. (1985). Universe of US Commercial-Scale Anaerobic Digesters: Results of SERI/ARD Data Collection. Golden, CO: Solar Energy Research Institute. Work performed by Associates in Rural Development, Inc., Burlington, VT. 
Case Study 4.3: $\quad$ Agway Farm

\begin{tabular}{ll}
\hline CONTACTS & Stan Weeks \\
\hline Address: & 6978 Route 80 \\
& Tully, NY 13159-9513
\end{tabular}

Telephone: $\quad 315.683 .5700$

GENERAL SYSTEM INFORMATION

Farm Type: Dairy.

Herd Size:

500 total head with manure from 250 manure from milkers used.

System Type:

Vertical concrete slurry tank with no mechanical mixing.

Dimensions:

$28 \mathrm{ft} \times 20 \mathrm{ft}$ diameter.

Capacity:

$7,225 \mathrm{ft}^{3}$ working volume ${ }^{1}(54,000$ gal $)$.

Biogas Production: $\quad 12,000 \mathrm{ft}^{3} / \mathrm{d}(65 \%$ methane content).

Operational Date: $\quad 1981$.

1998 Status: $\quad$ Operational.

Project History: $\quad$ The Agway project is the result of management's interest in evaluating the technology in the wake of the optimism surrounding $\mathrm{AD}$ technology in the 1970s. Operating experiences here, using the manure of 170 milkers and at 2 other locations, have been used to improve system design and to define operating economics. Before 1987, the digester system handled a smaller volume and was constructed with concrete staves. Because of its size and less than desirable construction, the digester was replaced with a larger, poured-concrete design. Inside the current digester "... a vertical dividing wall separates the point of manure entry and exit. No mechanical mixing of the digester contents occurs within the digester. Manure is mixed by thermal activity fostered by a concentrating heat pipe on $\mathrm{a}[\mathrm{n}]$...interior wall. The effluent is displaced by incoming manure and flows by gravity from the top of the digester into the adjoining manure storage. Some of the solids can be diverted into the adjoining manure storage."1 
Maintenance History: Daily O\&M requirements are minimal, requiring about 10-15 minutes on average. They follow a consistent data collection protocol to monitor system performance. Parameters include checking condensate, digester and engine temperatures, engine oil levels, engine oil pressure, and recording biogas production. Major system overhauls are scheduled annually; one for the engine, as well as removing built-up solids from the digester. The basic overhaul requires 2-3 days, and the recovery of the digester system might add 3-4 more days. This procedure enables the system to consistently maintain a $95 \%$ availability factor.

Lessons Learned:

A concrete stave silo digester with a fiberglass roof, and a Fiat TOTEM engine/generator that required a biogas scrubber and gas compressor was initially used. Standard design now consists of a poured epoxy-coated concrete silo, 4 inches of urethane foam, and a special sealant inside the urethane to provide a gas- and liquidtight interior surface. This allows for higher pressures inside the digester that directly feeds the engine/generator without the need for a compressor. The biogas is no longer scrubbed to remove hydrogen sulfide; instead, frequent oil changes and keeping the engine hot by running it $24 \mathrm{hr} / \mathrm{d}$ has become the best method to reduce corrosion. An insulated housing area reduces the frozen manure problem in the winter and allows for greater winter biogas production. The system was converted to separate solids before introducing them into the digester. This results in a $20 \%$ volume reduction, making the remaining liquid materials more pumpable. The separation is also believed to reduce solids crusting in the digester. The 1998 focus is on composting the separated solids to produce a value-added animal bedding. The use of composted solids in this fashion has the potential to reduce mastitis.

COSTING INFORMATION

Siting Cost: $\quad$ Included in capital cost.

Capital Cost:

$\$ 175,000$ (about $\$ 1,000 /$ cow).

Annual O\&M Cost: $\quad$ Estimated to be $\$ 3,650$.

End-Use of Biogas: $\quad$ Electricity with thermal reclaim used for digester and 2 buildings.

Prime Mover Type: $\quad$ 18-kW 4-cylinder Mercruiser (GM) marine engine modified by Perennial Energy. At the time of the site visit, the engine had logged more than 15,000 operational hours since its last overhaul. This is far beyond the 8,500 hour operational life usually desired. 
ANNUAL SAVINGS

Electricity Production:

Estimated at 145,000-150,000 kWh.

Electricity Savings: $\quad$ Estimated at $\$ 17,000-\$ 18,000 . \$ 0.12$ is the $1998 \mathrm{kWh}$ charge, with no demand charge.

Thermal Production: $\quad$ "From the available data, it appears that about $30 \%$ of the energy in the biogas is recovered as hot water..." This is estimated to be the equivalent of 8,000-8,400 gal of propane.

Thermal Savings: $\quad$ Estimated at $\$ 5,600-\$ 5,800$ at $\$ 0.70 /$ gal propane.

End-Uses of Effluent: $\quad$ Digester effluent goes to a storage area to be land applied. Fertilizer value is estimated to be $\$ 100 /$ cow/year, but the value cannot be entirely attributed to the digester.

Other System Savings: $\quad$ Odor control is a significant advantage because the digestion process nearly eliminates the volatile acids present in raw manure.

Designer/Installer: $\quad$ Agway.

1. Koelsch, et al. (1988). On-Farm Biogas Systems Information Dissemination Project. Ithaca, NY: Cornell University, Department of Agricultural and Biological Engineering. 175 pages. 
Case Study 4.4: $\quad$ Fairgrove Farms, Inc.

\begin{tabular}{ll}
\hline CONTACTS & David or John Pueschel \\
\hline Address: & 6770 Balk Road \\
& Sturgis, MI 49091 \\
Telephone: & 616.651 .6646
\end{tabular}

GENERAL SYSTEM INFORMATION

Farm Type: Dairy.

Herd Size: $\quad 850$ total head with manure from 720 milkers used.

System Type: $\quad$ Plug-flow.

Dimensions: $\quad 120 \mathrm{ft}$ x $24 \mathrm{ft}$ x $12 \mathrm{ft}$ with a "V" bottom.

Capacity: $\quad 24,000 \mathrm{ft}^{3}(180,000$ gal $)$.

Biogas Production: $\quad 50,000-57,000 \mathrm{ft}^{3} / \mathrm{d}(60 \%$ methane content).

Operational Date: 1981.

1998 Status: $\quad$ Operational.

Project History: $\quad$ The project was initiated when the farm owners started looking for a total answer to their manure management problems in combination with a desire to help control electricity costs. "This system is innovative in its construction. Most on-farm systems use a lined lagoon or tank with a soft plastic cover that can degrade or require special maintenance. The Fairgrove system has had no such problems. It has an insulated stress-core top over a [4 inch] concrete cover interrupted only by a baffle inspection hole. Further, the tank is buried under $2 \mathrm{ft}$ of soil." 1

Maintenance History: The system has experienced few problems. Manure is scraped from the free stall barns twice daily. Sand settling out of the manure has sometimes accumulated around the heat exchanger and blocked effective digester heating. Operators solve this problem by cleaning the heat exchanger system every 3 years. Ashworth ${ }^{2}$ reported that trapped sand caused the heat exchanger to break. The operators spend about $20 \mathrm{~min} / \mathrm{d}$ on general maintenance including loading the digester and maintaining the engine/generator system. Hydrogen 
Lessons Learned:

sulfide in the biogas is not scrubbed before fueling the engine/generator, which results in more frequent oil changes than might be conducted at a facility which removes hydrogen sulfide before combustion. Engine oil is replaced every 1,100 operating hours, about once a month.

The value has been unquestionable when measured in terms of energy savings, manure management, and the production of valuable coproducts for use as bedding and fertilizer. If there is a secret to the success of this system, the operators say it is the use of a hardcovered, well-built digester tank. Even though the original system was installed with a minimum of trouble-prone "bells and whistles," the operators have also spent time removing equipment that was found not to be necessary for operational success. Operators would also build a separate preheating tank to allow for grit settling before introducing the manure to the digester.

COSTING INFORMATION

Siting Cost:

Capital Cost:

Annual O\&M Cost:

End-Use of Biogas:

Prime Mover Type:
Included in capital cost.

$\$ 150,000$.

$\$ 6,000-\$ 7,000$, including the annualized cost of engine replacement.

Electricity production with thermal reclaim used for digester heating.

85-kW model 3306 Caterpillar modified by Perennial Energy. The current engine has been operating for more than 3 years without an overhaul.
ANNUAL SAVINGS

Electricity Production:
Previously estimated at 435,000-620,000 kWh. However, with an $85 \%$ availability factor, electricity production could be at 630,000 $720,000 \mathrm{kWh}$.

Electricity Savings:

Previously estimated to be $\$ 38,500^{2}-\$ 42,000^{1}$. However, at the 1998 electric rate of $\$ 0.105 / \mathrm{kWh}$, operators estimate the savings to be $\$ 48,000$.

Thermal Production: $\quad$ Used for digester heating.

Thermal Savings: Not applicable.

End-Uses of Effluent: $\quad$ Effluent is separated into solid and liquid fractions using a centrifuge. Solids reclaimed at this stage have a consistency like 
sawdust and are used as stall bedding for the animals. This material is pure and odor free, and the operators said that cows using this bedding have a lower incidence of mastitis than they did using conventional bedding. Bedding expenses are estimated to be reduced by as much as $\$ 3,000 /$ month. The liquid effluent flows by gravity into a storage lagoon. The liquid effluent is used as a fertilizer and is spread directly on fields using a boom system for better coverage. Some liquids are pumped up to 4 miles prior to land application. Liquids are applied at a rate of 5,000 gal/acre, which offsets the need for $100 \mathrm{lb}$ of nitrogen, $25 \mathrm{lb}$ of phosphate, and $100 \mathrm{lb}$ of potassium. The operators believe this results in a saving of \$25-\$30/acre. In $1985^{1}$ it was reported that the annual value of other benefits was $\$ 18,000$, although that figure seems quite low today.

Other System Benefits: $\quad$ Fly and odor control.

Designer/Installer: $\quad$ Perennial Energy, Inc. and modified by Fairgrove Farms.

1. Cliburn, J., et al. (1993). Biogas Energy Systems: A Great Lakes Casebook. Chicago, IL: Council of Great Lakes Governors, Great Lakes Regional Biomass Energy Program. 38 pages.

2. Ashworth, J. (1985). Universe of US Commercial-Scale Anaerobic Digesters: Results of SERI/ARD Data Collection. Golden, CO: Solar Energy Research Institute. Work performed by Associates in Rural Development, Inc., Burlington, VT. 
Case Study 4.5: $\quad$ Foster Brothers Farm

\begin{tabular}{lll|}
\hline CONTACTS & Robert L. Foster & Don Brumfield \\
\hline Address: & RD \#3, Route 166 & Vermont Natural Ag Products \\
& Middlebury, VT 05753 & $\begin{array}{l}\text { 559 Lower Foote Street } \\
\text { Middlebury, VT 05753 }\end{array}$ \\
Telephone: & 802.388 .6234 & 802.388 .0156 \\
\hline GENERAL SYSTEM INFORMATION & \\
\hline
\end{tabular}

Farm Type: $\quad$ Dairy.

Herd Size: $\quad 635$ total head with manure from 340 milkers used.

System Type: $\quad$ Plug-flow with XR-5 cover material.

Dimensions: $\quad 96 \mathrm{ft} \times 48 \mathrm{ft} \times 7 \mathrm{ft}$.

Capacity: $\quad 32,250 \mathrm{ft}^{3}(241,000 \mathrm{gal})$.

Biogas Production: $\quad 28,000 \mathrm{ft}^{3} / \mathrm{d}^{\text {reported }}{ }^{1}$. However, given current level of electricity production, probably $35,000-40,000 \mathrm{ft}^{3} / \mathrm{d}$.

Operational Date: $\quad 1982$.

1998 Status: $\quad$ Operational.

Project History: The project was initiated as a result of concerns regarding manure management and the energy crises of the 1970s. The project was designed to accommodate frozen manure in the winter assembled from push-off areas at the free-stall barns. The digester labor requirement had to complement the labor requirement used in stall scraping and feeding chores. Adequate manure storage and ease of application were both important considerations. The plug-flow design is viewed as having an advantage because uniform temperatures are not required throughout the digester, and the reduction in thermal stress of the bacteria provides a higher yield of biogas. $^{2}$

Maintenance History: The digester has had 2 manual clean-outs since 1982. Normal maintenance, consisting primarily of engine oil changes every $300-$ 400 hours, is also done as scheduled. Biogas clean up for removing hydrogen sulfide consists of limestone flakes in a plastic barrel. 
Minor mechanical pump failures, but no major problems, have been reported.

Lessons Learned:

An improvement would be to use a single manufacturer for engine generator and related electrical switch gear. Another would be to put in a neck chain sump for mechanical clean-out rather than rely on manual cleaning. Also, there is a substantial commitment required for the long haul when developing the infrastructure and markets for "over-the-counter" bagged solids. Bulk sales might be a better opportunity for most operators.

COSTING INFORMATION

Siting Cost:

Capital Cost:

Annual O\&M Cost:

End-Use of Biogas:

Prime Mover Type:
Not available.

$\$ 185,000$ when installed in 1982. Modifications to the engine/generator and effluent handling have cost an additional $\$ 115,000$. Operator estimates costs for the full use of effluent solid materials has been about $\$ 450,000$.

$\$ 8,000^{1}-\$ 12,000$.

Electricity production with thermal reclaim used for digester heating.

Original prime mover was a $125-\mathrm{kW}$ model 353 Caterpillar natural gas engine/generator. Although the original prime mover is still installed, lower buy-back rates for excess electricity led to the installation of a 85-kW model 3304 Caterpillar diesel engine which was modified to operate on a dual-fuel (biogas and diesel) basis for load displacement. This engine has operated for more than 50,000 hours with only minor work done on its head.
ANNUAL SAVINGS

Electricity Production:

Electricity Savings:

Thermal Production:

Thermal Savings:

End-Uses of Effluent:
Estimated at 450,000-510,000 kWh.

Previously estimated ${ }^{1}$ at $\$ 40,000$ when facility sold power. The 1998 on-peak energy charge is $\$ 0.281 / \mathrm{kWh}$, with no demand charge. System works on a displacement basis only with no sales of excess electricity production.

Used only for digester heating.

Not applicable.

Digester effluent is run through a screw-type dewaterer. Liquid effluent is sprayed on fields with irrigation guns. Dewatered solids 
are composted. Formerly used as bedding, solids are composted and are now sold as 7 soil amendments (potting soil, germinating mix, etc.) through Vermont Natural Ag Products, Inc. This gives an opportunity to export nutrients from the farm that would otherwise accumulate in excess of own needs.

Other System Savings: $\quad$ The digester is centrally located on the farm, and is viewed as an integral component of the farm's manure management system. It generates a better product than other manure management options. Odor reduction is also viewed as a major benefit of the system. The total value of the intangible benefits provided by the digestion system are estimated to be $\$ 40 /$ cow/year.

Designer/Installer: Hadley and Bennett.

1. Ashworth, J. (1985). Universe of US Commercial-Scale Anaerobic Digesters: Results of SERI/ARD Data Collection. Golden, CO: Solar Energy Research Institute. Work performed by Associates in Rural Development, Inc., Burlington, VT.

2. Foster, R. (1983). Integrating Methane Production and Irrigation Systems, 5 pages. Unpublished article. 


\section{Case Study 4.6: $\quad$ Langerwerf Dairy}

CONTACTS Leo and Linda Langerwerf

Address:

1251 Durham-Dayton Highway

Durham, CA 95938

Telephone: $\quad 530.893 .3131$

GENERAL SYSTEM INFORMATION

Farm Type: Dairy.

Herd Size:

Digester originally sized for 600 milkers. The 1998 herd size is 700 head with manure from 340 milkers used. Will be expanding the milking herd to 400 milkers in 1999.

System Type: $\quad$ Plug-flow with hypalon cover material.

Dimensions: $\quad 125 \mathrm{ft} \times 25 \mathrm{ft} \times 14 \mathrm{ft}$.

Capacity: $\quad 43,750 \mathrm{ft}^{3}(327,000$ gal $)$.

Biogas Production: $\quad 30,000 \mathrm{ft}^{3} / \mathrm{d}^{\text {design }}{ }^{1}(60 \%$ methane content). $15,000-20,000 \mathrm{ft}^{3} / \mathrm{d}$ in 1998.

Operational Date: $\quad 1982$.

1998 Status: $\quad$ Operational.

Project History: $\quad$ The project was initiated to take advantage of the California Department of Food and Agriculture's low-interest loan program that was available to dairies for installing anaerobic digesters as an alternative manure management tool. After examining several systems, a plug-flow was selected because the digested solids could be more readily recovered before discharge into a storage pit after scrape collection. This reduced some of the problems and expenses associated with using spreader trucks, which previously pumped materials from the storage pit for land application. The project was slowed in its initial start up because of a lack of labor and knowledge of system operation. The digester is housed in an innovative low-cost greenhouse, which protects it from wind damage and rainwater collection. However, after 16 years of continuous running, key components of the system are at the end of their functional lives. 
Maintenance History: $\quad$ Normal maintenance consists of a visual inspection of the digester solids loading rate (11\%-14\% TS concentration is desired) and engine/generator oil levels. The biogas is filtered through an mercaptan filter to remove hydrogen sulfide before combustion. The engine is run continuously, except for scheduled oil changes every 400-500 hours. A new engine head is installed every 6,000 hours at a cost of $\$ 800$. Down time for the head change is about 2 hours. The engine is totally rebuilt every $28,000-32,000$ operating hours at a cost of $\$ 10,000-\$ 12,000$. The engine block has more than 150,000 operating hours.

Lessons Learned:

The main project drawback was its investment cost, although there were minor problems associated with learning proper digester operating temperature, $\mathrm{pH}$, and feeding requirements. There has been additional stress associated with equipment maintenance. With the scheduled digester rebuild, the Langerwerfs are considering installing a shorter digester cover. The current digester cover is $8-9 \mathrm{ft}$ tall, the plan is to install one only $4 \mathrm{ft}$ tall. This will allow the height of the greenhouse to be reduced, avoiding possible wind shearing. They would like to move the engine/generator closer to the digester. This would reduce condensation in biogas, as well as loss of thermal energy used for digester heating. It would also reduce the chances for an engine fire damaging farm structures.

COSTING INFORMATION

Siting Cost:

Capital Cost:

Annual O\&M Cost:

End-Use of Biogas:

Prime Mover Type:
Not available.

$\$ 200,000$, which included the digester, solids separating system, and all ancillary equipment. Half the project was funded using a lowinterest loan. The balance of project costs were funded with a commercial loan through the local Production Credit Association.

Not available.

Electricity production with thermal reclaim used for milking facility hot water heating and residential space heating.

85-kW model 3306 Caterpillar engine, which generally operates at a load displacement level of 40-kW. 
ANNUAL SAVINGS

Electricity Production:

Electricity Savings:

Thermal Production:

Thermal Savings:

End-Uses of Effluent:

Other System Savings:
Estimated at 300,000 kWh when the system is fully functional. With the lesser herd size and aged digester inefficiency, 1998 electricity production is estimated to be $190,000-230,000 \mathrm{kWh}$.

$\$ 22,000-\$ 27,000$ at an energy charge of $\$ 0.12 / \mathrm{kWh}$ in 1998 , with no demand charge. Savings could be $\$ 36,000-\$ 40,000$ when the facility is returned to a fully functional status and milking herd size. The system operates on a net metering basis.

Not available.

$\$ 15,000$, with water heating savings estimated to average about $\$ 1,000 /$ month.

Liquids are pumped into an irrigation line and land applied yearround basis. Could consider using the liquids for algae production to be used as a source of animal protein. Currently feeding the cows a ration of distillers dried grains and solubles ( $36 \%$ protein) at a cost of $\$ 4,000 /$ month. Separated solids are used for freestall and calf barn bedding and also sold as garden mulch to local gardeners at $\$ 6.00 / \mathrm{yd}^{3}$. Any excess solids are spread onto fields during planting to increase soil tilth. Would like to consider developing a bagged compost as a value-added product.

Manure solids sales are about $\$ 6,000 /$ year. Savings resulting from reduced number of manure pit clean-outs are estimated to be $\$ 9,000 /$ year. Unquantified benefits from fly and odor control. "Unlimited possibilities if you keep your mind open."

Designer: $\quad$ Resource Conservation Management, Inc.

Installer: $\quad$ Lee Miller.

1. Langerwerf, L. (1989). Integrated Systems for Waste Management and Energy Generation: Langerwerf Dairy Biogas Generation System, 3 pages. Unpublished article. 
Case Study 4.7: $\quad$ Royal Farms

\begin{tabular}{ll}
\hline CONTACTS & Roy Sharp \\
\hline Address: & 20174 Road 140 \\
& Tulare, CA 93274
\end{tabular}

Telephone: $\quad 209.688 .2051$

GENERAL SYSTEM INFORMATION

Farm Type: Swine (farrow-to-finish).

Herd Size:

16,500 total head with 1,650 sows normally.

1998 herd size is substantially less due to market conditions.

System Type: $\quad$ Covered lagoon with hypalon cover material.

Dimensions: $\quad 205 \mathrm{ft} \times 205 \mathrm{ft} \times 25 \mathrm{ft}$.

Capacity: $\quad 1,050,000 \mathrm{ft}^{3}(5,574,096$ gal).

Biogas Production: $\quad \quad 70,000 \mathrm{ft}^{3} / \mathrm{d}(70 \%-80 \%$ methane content).

$25,000-28,000 \mathrm{ft}^{3} / \mathrm{d}$ in 1998 due to reduced herd size.

Operational Date: $\quad 1982$.

1998 Status: $\quad$ Operational.

Project History: $\quad$ The current manure management program started in 1972 with the objective of supporting a large animal population in a confined area that meets or exceeds public health and environmental standards. The need to reduce flies, dust, and odors led to the design and installation of a system using hydraulic manure flushing into a 3-cell lagoon. The energy crisis predictions of high electricity prices precipitated a focus on renewable energy resources. Because biogas was known to be a by-product of the lagoon's digestion process, the California Energy Commission funded a feasibility study. Conventional complete-mix and plug-flow digesters were evaluated and rejected because of the desire for a low-cost digester, and the study led to the decision to install a system using a simple floating cover attached to a retaining wall on the first cell of the lagoon. Royal started with only a 1/3 acre cover over the first-cell lagoon because of cost, and eventually covered the entire first cell and added a second engine/generator in 1987. Royal Farms borrowed the 
Maintenance History:

money to install the cover, and paid the loan in 2 years. The greatest perceived benefit is that the technology is a complete manure management system, providing odor reduction, with essentially no dust or flies on premises. Additionally, no nitrates were found in a groundwater test done by the USDA. Given the success of this project, 2 other swine farms have also installed floating covers: Sharp Ranch (550 sows) and Caruthers Ranch (900 sows). Both farms produce electricity with $75-\mathrm{kW}$ Waukesha induction generators.

Performance of the floating cover has been satisfactory, but some problems have occurred with wind and cover tie-downs. There have been very few cover puncture problems, which have been easily repaired because of the type of cover material. The cover exhibits no visible signs of deterioration after 16 years in the field. Cover skirts were weighted at $6 \mathrm{ft}$, but will sometimes surface and cause a loss of biogas. A 5-minute daily inspection is average, but there may not be an investigation for 4-5 days. A slow-down in gas production is the cue that there is a problem with the digester. Engine oil changes are performed every 450 hours on the average, using a high ash oil developed for natural gas engines. The engines selected for the project were expensive, but provide a $95 \%-96 \%$ availability factor including engine overhauls. There is usually 40,000-46,000 hours between engine overhauls. The fact that slightly oversized engines were installed, combined with the type of engine oil and frequency of oil changes, may be the reason for relatively long time between overhauls. Biogas cleaning is done by a proprietary chemical filter system which should be changed every 2,000 hours. Filters have not been maintained, with no detected difference in engine performance.

Lessons Learned: $\quad$ The farm would essentially do the same thing, except install a heavier cover. Sharp Energy is patenting a modular cover that will act as an insulator and help drain off rain and snow. The use of better quality equipment on the front end, even if it costs more, is important because over the life cycle of the system the investment will pay out. This was found to be especially true on the Caruthers Ranch project where a less expensive engine was destroyed by hydrogen sulfide, which corroded copper and bronze fittings. Also would use aluminum fittings to the extent possible.

COSTING INFORMATION

Siting Cost:

Not available.

Capital Cost:

$\$ 89,000$ for initial project. Expansion estimated to be $\$ 131,000$. Total cost is estimated to be $\$ 220,000$. 
Annual O\&M Cost: $\quad$ Estimated to be $\$ 8,000$.

End-Use of Biogas: $\quad$ Electricity production with hot air reclaim used for supplemental heating in nursery barns.

Prime Mover Type: $\quad$ 75-kW Waukesha induction generator modified by Perennial Energy initially installed. 100-kW Waukesha installed during project expansion.

ANNUAL SAVINGS

Electricity Production:

Electricity Savings:

Thermal Production:

Thermal Savings:

End-Uses of Effluent:

Other System Savings:

Designer:

Installer:
700,000-750,000 kWh when farm is fully populated. In 1998 electricity production about $35 \%-40 \%$ of this potential because of reduced herd size.

When farm is fully populated, offset power bills and excess generation sales at a $\$ 0.026 / \mathrm{kWh}$ avoided cost rate save $\$ 43,000$ $\$ 44,000$. The 1998 savings are about $35 \%-40 \%$ of this potential.

Not available.

$\$ 5,000$.

Effluent recycled from third lagoon is used for parlor flushing and the excess is irrigated.

Substantial savings resulting from reduced number of lagoon cleanouts. The primary lagoon was cleaned for the first time in 1997. This was done without disturbing the cover by using pumps to move the biosolids to a drying area, from where it was later applied as an odorless powder soil amendment to corn, wheat, and silage crops. It was found it to be a good thing, and will pump the biosolids annually until the sludge level is stabilized in the lagoon. "Anaerobic digestion is the only renewable energy resource that creates multiple environmental benefits, including displacing fossil fuels, destroying pathogens, and stabilizing nutrients."

Jeff Chandler.

Sharp Energy. 
Case Study 4.8: $\quad$ Brendle Farms

\begin{tabular}{ll}
\hline CONTACTS & Mike Brendle \\
\hline Address: & 252 School House Road \\
& Somerset, PA 15501
\end{tabular}

Telephone: $\quad 814.443 .3141$

GENERAL SYSTEM INFORMATION

Farm Type: Caged layer.

Herd Size: $\quad 75,000$ layers.

System Type: $\quad$ Slurry-based loop.

Dimensions: $\quad 14 \mathrm{ft} \times 42 \mathrm{ft}$ diameter digester.

$40 \mathrm{ft} \times 14 \mathrm{ft} \times 10 \mathrm{ft}$ flat bottom preheating tank.

Capacity: $\quad 19,400 \mathrm{ft}^{3}(145,000$ gal $)$ digester.

$5,600 \mathrm{ft}^{3}(42,000$ gal $)$ pre-heating tank.

Biogas Production: $\quad 28,000 \mathrm{ft}^{3} / \mathrm{d}^{2}$ estimated $(60 \%-65 \%$ methane content).

1983.

1998 Status: $\quad$ Operational.

Project History: $\quad$ The operator had an interest in AD based on past work in graduate school, wanted to be innovative, and to save money by converting a manure problem into a resource. The interest was furthered by the results of a feasibility study done by the NRCS area engineer. The digester operates at about $103^{\circ} \mathrm{F}$ with an $8 \%$ TS concentration and a 17-22 day HRT. In 1990, Robert Brendle (Mike's father) was awarded the "Governor's Energy Award for Outstanding Contribution to Pennsylvania's Energy Security."

Maintenance History: $\quad$ Basic daily maintenance is about 5 minutes, and includes checking the engine oil, oil pressure, and fan belt tension. Engine oil is changed every 2-3 weeks (350-450 hours). The engine has been rebuilt twice since 1983 . Limestone is removed from a preheating tank every 6-8 weeks, with up to 8 hours ${ }^{1}$ required for removal and flushing. Limestone has been removed from the digester only twice since the digester went online. 
Lessons Learned:

The original engine ran at $900 \mathrm{rpm}$, not fast enough to oil the engine properly. After the first engine was rebuilt in 1.5 years, engine rpm was increased to 1,200 by advancing the timing. The rebuilt engine lasted almost 7 years before a non-digester related fire on the farm shorted electrical lines and dropped safety switches, causing the engine to burn out when the cooling system failed. Also the need to keep engine and electrical equipment away from the digester to prevent corrosion caused by hydrogen sulfide was discovered. Some time was spent developing a preheating tank, which was primarily installed to allow limestone grit and feathers to settle out before entering the digester. It was found that the preheat tank also allows the manure to heat up before entering the digester, helping to prevent it from having a thermal shock in the winter. This tends to stabilize biogas production, especially in the winter. Turn-key system replacement cost is estimated to be about $\$ 2.00 /$ laying hen, and the monetary benefit of having the digester is about $\$ 0.01-\$ 0.015 /$ dozen eggs produced.

COSTING INFORMATION

Siting Cost:

Not available.

Capital Cost:

$\$ 125,000$ for the initial system. The preheat tank cost an additional $\$ 15,000$ and the new engine installed after the fire cost $\$ 17,500$.

Annual O\&M Cost:

Not available, but estimated to be $\$ 5,000$ for materials and equipment. $^{1}$

End-Use of Biogas: $\quad$ Electricity production with thermal reclaim.

Prime Mover Type: $\quad$ 65-kW model 3306 Caterpillar natural gas engine/generator.

ANNUAL SAVINGS

Electricity Production:

Electricity Savings:

Thermal Production:

Thermal Savings:

End-Uses of Effluent:
Estimated to be $365,000 \mathrm{kWh}$ (about 1,000 kWh/d)

Estimated at $\$ 30,000-\$ 35,000$. The 1998 energy charge is $\$ 0.086 / \mathrm{kWh}$, with no demand charge.

Excess heat is used to preheat wash water for egg processing and for heating the egg packing area and office. Space and water heating were previously electric.

Included above.

Discharged effluent is stored in a lagoon, and liquids are later spray irrigated onto croplands. Limestone recovered from the preheat tank 
is stockpiled. The limestone is later land applied at a rate of 400

$\mathrm{lb} / \mathrm{acre}$ on land used to grow corn, oats, and hay.

Other System Savings: $\quad$ The nutrient value of the land-applied effluent is about $\$ 20,000 /$ year. Other system benefits include odor and fly control.

Designer:

Bert Waybright (Mason-Dixon Farm).

Installer:

Brendle Farms.

1. Bogovich, W. (1995). Poultry Power for Long-Term Profit. Unpublished project report. 


\section{Case Study 4.9: $\quad$ Darrell Smith Farm}

\begin{tabular}{ll}
\hline CONTACTS & Darrell Smith \\
\hline Address: & Route 2, Box 45 \\
& Princeton, NC 27569
\end{tabular}

Telephone: $\quad 919.734 .6107$

GENERAL SYSTEM INFORMATION

Farm Type: Poultry.

Herd Size: $\quad 70,000$ caged layer hens.

System Type: $\quad$ Complete-mix with metal tank.

Dimensions: $\quad 28 \mathrm{ft} \times 31 \mathrm{ft}$ diameter.

Capacity: $\quad 21,000 \mathrm{ft}^{3}$ working volume $(158,000$ gal).

Biogas Production: $\quad 17,000 \mathrm{ft}^{3} / \mathrm{d}$ initially (58\% methane content $)^{1}$

21,000 $\mathrm{ft}^{3} / \mathrm{d}$ through 1997 (62\% methane content $)^{2}$

42,000 $\mathrm{ft}^{3} / \mathrm{d}$ estimated mid-summer 1998

Operational Date: 1983.

Modifications should be completed by fall 1998.

1998 Status: $\quad$ Operational.

Project History: $\quad$ The project was initiated to control odor and for other environmental concerns. Because a $\$ 0.11 / \mathrm{kWh}$ electrical buy-back rate was offered by the local power company when the project began operating, the initial operating strategy was to store the biogas and generate electricity for sale at peak demand periods. A floating cover added in 1985 as part of a research project ${ }^{3}$ was dismantled in 1995 when the fabric failed. The digester was originally designed to operate at about $103^{\circ} \mathrm{F}$ with a $5.5 \%$ TS concentration and a $21-23$ day HRT.

In 1997, Duke Engineering and Services (DE\&S) formed a partnership with Smith Farms to undertake extensive modifications to the system to operate it at the thermophilic $\left(130^{\circ}-140^{\circ} \mathrm{F}\right)$ temperature range with a TS concentration of up to $8.0 \%$. This strategy should allow the processing of twice as much organic material with the fixed volume of the digester by reducing the 
biomass HRT. These modifications were made to increase digester gas production to enable electricity generation $24 \mathrm{hr} / \mathrm{d}$. The modifications were also made to produce a line of soil amendments, and organic fertilizer coproducts, thus yielding additional revenue streams.

As already mentioned, the thermophilic operation should be able process more biomass than the original design. However, more heat input is required to keep the digester up to temperature, particularly in winter. To conserve heat, the process uses a redesigned heat exchanger to preheat the incoming feed with the outgoing digester effluent. Primary heat is provided by an existing exchanger in the digester, which uses hot water from jacket cooling of the engine/generator. A piped-in back up package boiler is available should the engine be shut down. The solids accumulated on the screen are drawn through a wringer that squeezes out excess moisture and produces a cake that can then be handled as a solid. This cake is produced in the litter storage building where it can be air dried or blended with other materials. The filtrate liquid from the separator is pumped to a storage tank. Filtrate is to be used as a liquid fertilizer because it is estimated that $60 \%$ of the processed nutrients are remaining in it.

Various types of food residues are also being experimentally blended with the manure feedstock to chemically balance the overall feedstock for increased gas production and increased nutrient value. This could also provide additional project revenues through tipping fees for organic residues not otherwise easily disposed of.

Maintenance History:

About $1 \mathrm{hr} / \mathrm{d}$ is spent monitoring the digester. The digester historically was fed a total of 6,355 gal of manure each day. Also, a number of engine/generator problems were reported, primarily related to the undersizing of the cooling system. A faulty casting also cracked the engine head. The generator control panel was replaced because of corrosion caused by hydrogen sulfide. Additional maintenance was needed because of grit buildup on the digester tank's bottom. Long-run experience has shown that the digester needs to be cleaned out every $4-5$ years.

Lessons Learned:

"One of the major problems encountered...has been the grit in the manure...At manure solids contents less than 8\%-9\% TS, the grit will settle in a short time. To reduce the amount of grit reaching the digester, a strategy of mixing the manure, letting the grit settle (2-10 minutes) and pumping the supernatant to an adjacent pit was 
developed. The degritted manure was then fed to the digester as needed."1

COSTING INFORMATION

Capital Cost:

$\$ 225,000$ for primary system. Costs for 1998 revision not available.

Annual O\&M Cost: $\quad$ Estimated to be $\$ 5,000$.

End-Use of Biogas: $\quad$ Electricity with thermal reclaim used for heating digester.

Prime Mover Type: $\quad$ 80-kW Minneapolis-Moline.

ANNUAL SAVINGS

Electricity Production:

Electricity Savings:

Thermal Production:

End-Uses of Effluent:

Original Designer:

Original Installer:

$2^{\text {nd }}$ Design/Install:
$300,000 \mathrm{kWh}$ with original on-peak operating strategy.

$520,000 \mathrm{kWh} 1996$ estimate.

Estimate for 1998 not available.

Originally $^{1}$ estimated to be $\$ 26,000$. 1998 savings not available.

Not applicable.

Originally landspread from lagoon with some manure re-fed into digester. Current strategy is to produce a product line of compost, soil amendments and organic fertilizers

Bio-Gas of Colorado and A.O. Smith Harvestore (Dr. R.L. Vetter).

1. Safley, L.M.; Vetter, R.; Smith, D. (1987). “Operating a Full-Scale Poultry Manure Digester.” Biological Wastes 19:79-90.

2. Vetter, R.L. (30 November 1996). Personal Communication. Agri-BioSystems, Inc., Elgin, IL.

3. Safley, L.M.; Westerman, P. (1989). “Anaerobic Lagoon Biogas Recovery Systems.” Biological Wastes 27:4362. 
Case Study 4.10: $\quad$ Oregon Dairy Farm

\begin{tabular}{ll}
\hline CONTACTS & George and Mary Hurst \\
\hline Address: & 2870 Oregon Pike \\
& Lititz, PA 17543
\end{tabular}

Telephone: $\quad 717.656 .7305$

GENERAL SYSTEM INFORMATION

Farm Type: Dairy.

Herd Size:

300 total head with manure from 250 milkers used.

System Type: $\quad$ Slurry-based loop with Hypalon cover material.

Dimensions: $\quad 12 \mathrm{ft}$ x $40 \mathrm{ft}$ diameter.

Capacity: $\quad 15,000 \mathrm{ft}^{3}(113,000$ gal $)$.

Biogas Production: $\quad 18,000-20,000 \mathrm{ft}^{3} / \mathrm{d}$ estimated (60\% methane content).

Operational Date: 1983.

1998 Status: $\quad$ Operational.

Project History: $\quad$ The project was initiated as a result of concerns about future energy costs. Additional encouragement was provided by the local electric utility's need for capacity and by the $10 \%$ federal energy tax credit that was in place before the Tax Reform Act of 1986. An additional reason for implementation was odor control. The digester was designed to operate with a $10 \%-12 \%$ TS concentration and a 20 day HRT. A preheating tank was installed to avoid shocking the digestion system. Foaming was found to happen only when the preheat tank was not used.

Maintenance History: $\quad$ There have been no major problems to report. The staff performs a 15-minute daily walk-through inspection, mainly checking engine oil and manure pumps, and monitoring manure flow. A major engine overhaul (down to bearings) was performed in 1988. Formerly an iron sponge was used to strip hydrogen sulfide from biogas, but frequent oil changes have reduced the problem of hydrogen sulfides. The heat exchanger was replaced because the factory-built unit did not perform to specification. The black iron hot water pipe running 
Lessons Learned:

to the house lasted only 2 years and was replaced with a hightemperature plastic pipe. The side walls of the digester building were changed from steel to vinyl because of hydrogen sulfide corrosion.

The company would try to reduce the initial cost, but are unsure of the exact measures required. Although the project did not produce its estimated 10-year simple payback from energy offsets alone, they would do it again because of intangible benefits. The feeling is that only farms with 200-300 head and larger should consider implementing the system given present capital costs.

COSTING INFORMATION

Siting Cost:

Capital Cost:

Annual O\&M Cost:

End-Use of Biogas:

Prime Mover Type:
Included in turnkey price.

$\$ 120,000$ turn key.

$\$ 3,500-\$ 4,000$ ( $\$ 2,500$ on oil and filters and $\$ 1,000$ on the annualized cost of 5 year major rebuild of engine).

Electricity with thermal reclaim used for home heating.

50-kW model G333 Caterpillar gasoline engine, which was modified by advancing timing 30 degrees to operate on a dual-fuel basis for load displacement. Occasionally supplements biogas with propane when needed.
ANNUAL SAVINGS

Electricity Production:

Electricity Savings:

Thermal Production:

Thermal Savings:

End-Uses of Effluent:

Other System Savings:
200,000-250,000 kWh annually.

Estimated at $\$ 14,000-\$ 17,500$. The 1998 energy charge is $\$ 0.07 / \mathrm{kWh}$, with no demand charge.

Not available, but is used for home heating.

$\$ 1,200$ annually.

Digested manure pumped to lagoon and land applied. Formerly sold separated solids, but quit selling because market was saturated.

Easier manure management because of the slurry's more homogenous consistency. Unsure of specific nutrient value of digested manure, but does not have to add chemical fertilizers to effluent-applied lands. Also because manure is less acidic ( $\mathrm{pH}$ changes from 6.3 to 7.1 as a result of the digestion process), has to 
add less lime to soil. Still believes that the digestion system is the most cost-effective method for odor control.

Designer:

Bert Waybright (Mason Dixon Farm).

Installer:

Oregon Dairy Farms. 
Case Study 4.11: $\quad$ Cooperstown Holstein Corporation Farm

\begin{tabular}{ll}
\hline CONTACTS & Peter Huntington \\
\hline Address: & RR 4, Box 428 \\
& Cooperstown, NY 13326
\end{tabular}

Telephone: $\quad 607.547 .5053$

GENERAL SYSTEM INFORMATION

Farm Type: Dairy.

Herd Size: 490 total head with the manure from 270 milkers used. Considering an expansion in herd size to 460 milkers.

System Type: $\quad$ Complete-mix with metal tank.

Dimensions: $\quad 28 \mathrm{ft} \times 31 \mathrm{ft}$ diameter.

Capacity: $\quad 21,000 \mathrm{ft}^{3}$ working volume ${ }^{1}(158,000 \mathrm{gal})$.

Biogas Production: $\quad 23,625 \mathrm{ft}^{3} / \mathrm{d}^{\text {reported }}{ }^{2}(60 \%$ methane content). Now estimated to be around $25,000 \mathrm{ft}^{3} / \mathrm{d}$ ( $60 \%$ methane content).

Operational Date: $\quad 1985$.

1998 Status: $\quad$ Operational.

Project History: The digester was installed as a component of a major upgrade to the farm's entire manure management system, which was geared to allow growth in herd size. In addition to the digester and its control room, the upgrade included: 3 manure pits, a pump, and an underground line from the main barns to the digester-storage facility, the gravity flow line from the heifer barn, and a 1 million gal slurry storage tank. The system used to have a compressor and storage tank to send the biogas to a nearby retirement home. However, changes in market conditions in 1994 caused to owners to pursue the electrical cogeneration option, which finally worked out in 1997. During its first year of operation, the cogeneration system operated continuously except for scheduled maintenance. Purchased electricity was basically nil.

Maintenance History: Daily O\&M requirements include reading 16 metering instruments, calculating the amount of slurry added to the digester, draining the 
Lessons Learned:

condensate from the water trap of the iron sponge used for scrubbing hydrogen sulfide, and checking the engine's oil level. The daily routine requires 15-20 minutes and includes monitoring overall system performance and adjustment of the digester's heat exchanger system. Engine oil is changed every 300 hours. The digester's feeding system originally had an automatic control system, but the control system wiring burned out; consequently, the digester had to be fed manually. In spring 1998, a pump used for influent tank manure mixing failed, and its replacement caused a down time of 1 month. A 1 week scheduled maintenance to drain and clean the digester and make minor improvements occurred in 1997. Before that, the longest period that the digester was down occurred in 1988 for a 3-day cleaning to remove built-up solids. From 1988-1997, the system operated non-stop without an outage. After operating less than 1 year, the failure of the solids separator in 1987 led to the decision not to collect solids for use as bedding. However, with the increased herd size, a solids separator will now be used after digestion to create a bedding material. Any surplus solids will be bulk sold to other farmers as a bedding material.

The digester's manual feeding system reduced biogas production by $25 \%-30 \%$, and "adequate documentation on the wiring panels would have prevented this problem." "The automatic operation of the digester's feeding system was restored by an electrical contractor during September 1994. At the time the digester was down in 1988, the return flow of the slurry was repositioned by moving a mixing pump from the center of the digester to the wall. This was done to reduce thermal bridging impacts caused by builtup solids. The decision to install the engine/generator was not without complications. The electrical agreement allows no recognition of surplus sales, and although local utility personnel were cooperative, overall negotiations with the utility were frustrating. Intertie negotiations with the local electricity supplier were not encouraging, and inhibited prospects for a speedy contract.

COSTING INFORMATION

Siting Cost:

Included in capital cost.

Capital Cost:

$\$ 500,000$ for entire manure handling improvement operation. The engine/generator cost $\$ 24,000$ and the 1997 digester modifications were budgeted at $\$ 35,000$. 
Annual O\&M Cost: $\quad$ Previously estimated to be $\$ 4,125$ plus labor expenses ${ }^{1}$ when the compressor was used. Unknown with the installation of the engine/generator, but will likely be about the same.

End-Use of Biogas: $\quad$ Electricity production with thermal reclaim for digester heating and for farm sanitary wash water.

Prime Mover Type: $\quad$ Continental 65-kW.

ANNUAL SAVINGS

Energy Production: $\quad$ Likely averages 300,000-350,000 kWh.

Energy Offsets:

Estimated at $\$ 40,000-\$ 50,000$ at a blended electricity price of $\$ 0.17 / \mathrm{kWh}$.

Thermal Production: Given that about one-third of the biogas generated is used for digester heating, the project could still potentially recover all the thermal energy required for sanitary washing and still have a surplus. Part of the farm's challenge will be to find new opportunities for this resource. Possible uses include radiant floor heating and preheating animal drinking water.

Thermal Savings: Not available.

End-Uses of Effluent: $\quad$ Digester effluent is stored in slurry tank for later land application on corn. Annual effluent fertilizer value is estimated to be $\$ 25,000$ or more. Offsetting purchased sawdust with digested solids is estimated to save $\$ 10,000$. The nutrient management benefits are much more than expected. Moreover, the manure management system made a more efficient use of the farm's labor by being able to do away with daily spreading. This labor saving is estimated at 0.75 full-time equivalent.

Other System Savings: $\quad$ Would do an AD project solely for odor control. As farms get larger and concerns about nutrient management increase, AD will become a manure management option for the farm of the future.

Designer/Installer: $\quad$ A. O. Smith Harvestore/Dr. R. L. Vetter.

1. Koelsch, R., et al. (1989). Experience with Three Anaerobic Digestion Systems on Commercial Dairies. American Society of Agricultural Engineers Paper No. 89-6550. 17 pages.

2. Vetter, R.L., et al. (1990). Full Scale Anaerobic Digester and Waste Management System for a 300 Cow Dairy. Presented at the Sixth International Symposium on Agricultural and Food Processing Wastes, Chicago, IL, 17-18 December. Niles, MI: American Society of Agricultural Engineers; pp. 236-249. 
Case Study 4.12: $\quad$ BTI Gonzales R\&D and Production Plant

\begin{tabular}{lll}
\hline CONTACTS & Dr. Renato E. Lumbroso & \\
\hline Address: & $\begin{array}{l}\text { BioRecycling Technologies, Inc. } \\
\text { 6101 Cherry Avenue } \\
\text { Fontana, CA 92336 }\end{array}$ & $\begin{array}{l}\text { BTI-Gonzales } \\
\text { Old Stage Road } \\
\text { Gonzales, CA } 93926\end{array}$ \\
& 909.899 .2982 & 408.675 .0586 \\
Telephone: & 909.899 .9519 & 408.675 .2013 \\
FAX: & &
\end{tabular}

GENERAL SYSTEM INFORMATION

Farm Type: Dairy.

Herd Size: $\quad 1,600$ total head with manure from 400 milkers used.

System Type: $\quad 2$ complete-mix with metal tanks, configured as two-stage thermophilic reactors.

Dimensions: $\quad$ Not available.

Capacity: $\quad 15,000$ gal each.

Biogas Production: $\quad 11,000 \mathrm{ft}^{3} / \mathrm{d}(58 \%-60 \%$ methane content)

Operational Date: 1985 initially.

1992 substantial modification to original digester.

1995 new digesters installed.

1998 Status: $\quad$ Operational.

Project History: $\quad$ The project was initially built as a conventional anaerobic digester, in that use of the biogas for energy purposes was the principal objective. O\&M problems caused the digester to be shutdown in 1987. After converting the original digester to a proprietary process, BTI redirected the focus from energy production to the use of digested solids and liquid nutrients. The Gonzales plant site is mainly involved in testing the horticultural value of these recovered materials at an on-site research facility and with other organizations. BTI is currently in the construction phase of a facility located near Fresno, California. Please see Case Study 22 for further details.

Maintenance History: $\quad$ The original plug-flow digester had to be purged of a 3-ft layer of solids. BTI redesigned the plug-flow digester to operate as a 
Lessons Learned:

continuously stirred system operating under thermophilic conditions (approximately $131^{\circ} \mathrm{F}$ ). This redesigned system was replaced in 1995 by 2 vertical complete-mix "stir-tank" reactors. Although a $60-\mathrm{kW}$ engine/generator was originally installed, is has been replaced by a new dual-fueled boiler.

Zero effluent discharge is the company goal. BTI wishes to transform digested solids and liquids into the most valuable products, and thereby offer an economically attractive recycling solution to the disposal of animal manures. A new area of research is the conduct of field trials to measure increases in plant yield not necessarily related to the fertilizer value, i.e., trying to measure the impacts of the living microflora present in the coproducts that are simply not present in conventional fertilizer. The theory is that the microflora enhances plant vigor, resulting in an increase in crop yield. This can directly translate into more dollars/acre for the user. So far the results are quite encouraging. A recently completed trial on organic broccoli found yields were increased an average of $10 \%$. Moreover, the first cuttings were available for harvest from 7-10 days before the conventional control. This could provide an even greater financial benefit to a farmer who is able to market his product before competitors flood the market, thereby reducing price premium. Although BTI plans to eventually develop markets in row crop agriculture, its current focus is on high-value products such as broccoli, garlic, lettuce, and tomatoes.

COSTING INFORMATION

Siting Cost: Not available.

Capital Cost: $\quad$ Not available.

Annual O\&M Cost: $\quad$ Not available.

End-Use of Biogas: $\quad$ Thermal production for heating digester, drying finished products and other process requirements.

Prime Mover Type: $\quad$ Not available. 
ANNUAL SAVINGS

Electricity Production:

Electricity Savings:

Thermal Production:

Thermal Savings:

End Uses of Effluent:

Other System Savings:

Designer/Installer:
Not applicable.

Not applicable.

Not available.

Not applicable.

After leaving the digester, the digested slurry is separated into liquid and fiber fractions by using a revolving squeezing sieve separator. The liquid fraction undergoes additional centrifuge separation and generates a liquid "centrate" and a solid "cake." The centrate is used as an organic liquid fertilizer for organic farm practices or as an addition to conventional fertilizers. According to BTI, the centrate contains a wide spectrum of microflora, fine organic matter, and hormone-like substances, and its use has given very encouraging results in field trials. Other NutriPlus products, such as $N P-15$, are different formulations of bridge-organic liquid fertilizers obtained by stabilizing and enriching the centrate with traditional chemical products. The cake is processed with other organic materials to produce dry pellets of various sizes (NutriPellets). These are reportedly very convenient to use value-added specialty organic fertilizers. The fiber fraction is further combined with other selected agricultural by-products and undergoes a very controlled aerobic composting process. According to the specific formulas used, different specialized products are obtained. These include AlTex, a value-added organic potting soil and partial replacement for the peat moss used by the horticultural and ornamental markets, Agri-Blend, a soil amendment and fertilizer, and Agriturf, a top-dress material for golf courses.

BTI believes it integrates the most efficient processes into its systems. These processes include high-rate thermophilic AD, special separation techniques, and controlled aerobic digestion that results in the optimal added-value for each product. "Coproduct utilization is the key to financial success."

BioRecycling Technologies, Inc. 
Case Study 4.13: $\quad$ Rocky Knoll Farms

\begin{tabular}{ll}
\hline CONTACTS & Harlan Keener \\
\hline Address: & 1266 Gypsy Hill Road \\
& Lancaster, PA 17602
\end{tabular}

Telephone: $\quad 717.464 .2669$

GENERAL SYSTEM INFORMATION

Farm Type:

Herd Size:

System Type:

Dimensions:

Capacity:

Biogas Production:

Operational Date:

1998 Status:

Project History:
Swine (farrow-to-finish).

Normally 13,000 total head with 1,000 sows. Has 2,000 finishing hogs in 1998. Also codigesting dairy whey and other dairy processing residues.

Complete-mix with XR-5 cover material.

$28 \mathrm{ft} \times 143 \mathrm{ft} \times 14 \mathrm{ft}$ (deepest point).

$46,800 \mathrm{ft}^{3}(350,000 \mathrm{gal})$.

$60,000 \mathrm{ft}^{3} / \mathrm{d}(60 \%-62 \%$ methane content). Probably producing $40,000-45,000 \mathrm{ft}^{3} / \mathrm{d}$ in 1998 .

1985.

Operational.

The project was initiated because of a desire to proactively reduce the risk of odor complaints by neighbors who live $600 \mathrm{ft}$ from the farm boundary. Beginning in 1995, the farm began to codigest milk processing byproducts after receiving a permit from state regulatory agency. Not only was biogas production increased, the farm received a tipping fee from the processing company. Later it was found that a permit was not required. The farm lost its normal herd size in 1996 because of disease. It nevertheless kept the digester working by continuing to codigesting milk processing byproducts. A mix of $80 \%-90 \%$ manure with milk processing byproducts was originally used; but since the herd loss, the mixture percentages have been reversed. A 4\%-5\% TS concentration and a 20-23 day HRT is maintained when possible. 
Maintenance History: An average of 10-20 min/d is spent checking engine oil levels and other system components. Frequent oil changes are performed on the engine/generator (every 360 hours). An iron sponge to strip hydrogen sulfide from biogas was formerly used, but hydrogen sulfides are no longer a significant problem due to frequent engine oil changes. The digester is kept at $100^{\circ} \mathrm{F}$ using waste heat discharged from the engine. The digester has never needed to be pumped out because of the low lignin content of the manure.

Lessons Learned:

"Mistakes are what you call experience." Originally has a plug-flow system that was modified by installing a side-mounted pump that agitates liquid in digester periodically to reduce crusting. The original building housing the digester was destroyed because of hydrogen sulfide emissions and replaced by a building with an open ridge vent to allow any collected gases to dissipate. Moving the digester further from other farm buildings would avoid contamination from engine exhaust gas discharge. There were leaks in pipes caused by electrolysis. The leaks were mitigated by installing zinc bars for cathodic protection. The use of building materials that do not corrode such as aluminum, as well as surplus materials to reduce first-cost are "lessons learned." It is also important to factor in a greater emphasis on gravity flow of manure.

COSTING INFORMATION

Siting Cost: Included in turnkey contract.

Capital Cost: $\$ 225,000+\$ 100,000$ for modifications.

Annual O\&M Cost:

Previously estimated to be $\$ 8,000$.

End-Use of Biogas:

Electricity production with thermal reclaim. Farrowing rooms and nursery normally have heating requirements partially supplemented from hot water reclaimed from engine/generator. Also uses hot water at $150^{\circ} \mathrm{F}$ for high-pressure wash down.

Prime Mover Type: $\quad$ 200-kW model 342 Caterpillar natural gas engine/generator, which generally operates with a load displacement of $125-\mathrm{kW}$. Has secondary 25-kW Kohler which runs during period of excess biogas production.

ANNUAL SAVINGS

Electricity Production: $\quad 1.0-1.2$ million $\mathrm{kWh}$.

Electricity Savings: $\quad$ Formerly estimated at $\$ 60,000-\$ 65,000$. Probably is offsetting $\$ 30,000-\$ 35,000$ in 1998 with an energy charge of $\$ 0.075 / \mathrm{kWh}$ and 
no demand charge. Also receives a tipping fee from dairy plant which is not included in these savings.

Thermal Production: $\quad$ Normally estimated at being the equivalent of 12 gal of propane/hour (1.1 million Btu/hour).

Thermal Savings:

Normally estimated at $\$ 40,000$ for heating season (September through April) at \$0.60/gal propane.

End-Uses of Effluent: $\quad$ Landspread on crops for nutrient value with a displaced fertilizer value of $\$ 15,000$ annually for the 250 acres that receive the effluent.

Other System Savings: $\quad$ No money spent on legal defense for odor complaints. Eases manure handling requirements and permits simpler application of nutrients when land-applied. "The digester is one of the best investments I ever made in farming because of no odor lawsuits from neighbors." Also found the financial return offered by the digestion system a surprising event, especially after herd loss.

Initial Designer/Installer: $\quad$ Energy Cycle, Inc.

$2^{\text {nd }}$ Designer/Installer: $\quad$ Rocky Knolls Farms 
Case Study 4.14: $\quad$ Carroll's Foods, Inc.

\begin{tabular}{ll}
\hline CONTACTS & Bob McLeod \\
\hline Address: & Post Office Box 856 \\
& Warsaw, NC 28398
\end{tabular}

Telephone: $\quad 919.293 .3434$

GENERAL SYSTEM INFORMATION

Farm Type: Swine (farrow-to-finish).

Herd Size: $\quad 11,500$ total head with 1,000 sows.

System Type: $\quad$ Covered lagoon.

Dimensions: $\quad 265 \mathrm{ft}$ x $265 \mathrm{ft}$ on surface $\times 24 \mathrm{ft}$ deep. 147 x $147 @ 24 \mathrm{ft}$ with a 2.5:1 sideslope.

Capacity: $\quad 935,400 \mathrm{ft}^{3}$ (7 million gal).

Biogas Production: $\quad 70,000 \mathrm{ft}^{3} / \mathrm{d}$ design ( $65 \%$ methane content). $35,000 \mathrm{ft}^{3} / \mathrm{d} 1998$ estimated average (80\% methane content).

Operational Date: $\quad$ XR-5 cover installed 1992.

Prime mover installed in 1994.

Polypropylene cover installed in 1997.

1998 Status: $\quad$ Operational.

Project History: $\quad$ In 1987, the North Carolina Energy Division and North Carolina State University constructed the first covered lagoon digester on the East coast at the Randleigh Dairy using funds provided by the DOE's Southeast RBEP, the North Carolina Agricultural Research Service, and the North Carolina Dairy Foundation. The Division's swine digester demonstration project is a substantial scale up of the Randleigh project. Its objective is to inform swine integrators and producers through practical demonstration and educational outreach about the merits of a lower-cost and more easily maintained digester suitable for use on farms using hydraulic flush manure management systems. Carroll's Foods was selected as the host cooperator following a Request for Qualifications process. Although the XR-5 cover was installed and collected biogas for 2 years between 1992 and 1994, electricity generation was delayed because of institutional 
Maintenance History:

Lessons Learned: problems with the facility's electric supplier. This was eventually resolved by allowing the engine to operate as an isolated unit. Then in 1995, the XR-5 cover ripped and sank. For a period, this project looked like a "poster child" for failed projects. In late 1996, Carroll's Foods and the Energy Division decided to rehabilitate the project and move forward once again. During the late summer of 1997, a new cover made of polypropylene and using a different design was installed. Although there have been some problems with the new cover design, it is expected to be fully validated by the end of 1998 .

Metering problems from particles wedged in the gas meter precluded measuring gas production.

The lift station would be designed differently, because there is no need to keep solids in suspension. The lift station sump would be made smaller as a result. The original cover attachment was earth-bermed, but did not seal because of dirt in the trench. It was necessary to mechanically seal the edges of the cover to the attachment apron. The biogas compressors were moved from being near the lift station to being closer to the engine room. The originally estimated biogas production level was not achieved due to wash-out of bacteria from the digester. It is likely biogas production would increase if the facility used less water for manure flushing, so long as animal health or worker safety were not compromised. Also, the nature of the interruptable rate schedule offered by the facility's electricity supplier makes it difficult to balance load and energy production from the engine.
COSTING INFORMATION

Siting Cost:

Capital Cost:

Annual O\&M Cost:

End-Use of Biogas:

Prime Mover Type:
$\$ 88,000$ (however, this amount includes additional costs due to the nature of the demonstration project).

$\$ 191,500$ (42\% Carroll's cost-share). Second cover installed at a cost of $\$ 26,000$.

Not available, but $\$ 8,000-\$ 10,000$ is estimated.

Electricity production with no thermal reclaim.

110-kW Model Caterpillar G3306. 
ANNUAL SAVINGS

Electricity Production:

Electricity Savings:

Thermal Production:

Thermal Savings:

End-Uses of Effluent:

Other System Savings:

$1^{\text {st }}$ Cover Designer:

Balance of System:

$2^{\text {nd }}$ Cover Designer:

Installer:
With the 1998 level of biogas production and an $85 \%$ availability factor, about 550,000-600,000 kWh could be produced annually.

Not available. The 1998 energy charge is $\$ 0.06 / \mathrm{kWh}$, with a $\$ 12.00 / \mathrm{kW}$ demand charge. Given the potential electricity production, annual electricity savings could be $\$ 45,000-\$ 50,000$.

Not applicable.

Not applicable.

Land application from a second lagoon cell. Interested in exploring the digester as an intermediate treatment step for nutrient management. Considering growing duckweed as a secondary source of nutrient removal, followed by chemical precipitation of remaining nitrogen and phosphorus.

Savings could result from a reduction in excess nitrogen disposal. "There are too many intangible benefits from odor control not to have a positive conclusion, but covering a lagoon and harvesting biogas from it still needs additional work."

Department of Biological and Agricultural Engineering, North Carolina State University.

Charles R. Browning and Associates.

Charles R. Browning and Associates.

Carroll's Foods of North Carolina. 
Case Study 4.15: $\quad$ Martin Farms

CONTACTS

Address:

Telephone:

GENERAL SYSTEM INFORMATION

Farm Type:

Herd Size:

System Type:

Dimensions:

Capacity:

Biogas Production:

Operational Date:

1998 Status:

Project History:
Debbie and Harold Martin

Rt. 1 Box 310

South Boston, VA 24592

804.476.6613 (barn)

Swine (farrow-to-feeder).

3,000 total head with 600 sows.

Covered lagoon with XR-5 cover material.

$120 \mathrm{ft} \times 120 \mathrm{ft} \times 27 \mathrm{ft}$.

$389,000 \mathrm{ft}^{3}$ (2.9 million gal).

$12,000 \mathrm{ft}^{3} / \mathrm{d}$ average $(80 \% \text { methane content })^{1}$.

$14,000 \mathrm{ft}^{3} / \mathrm{d}$ in summer, with winter less than $6,000 \mathrm{ft}^{3} / \mathrm{d}$.

Original cover installed in 1993.

Prime mover installed in 1994.

Second cover installed in 1997.

Operational.

Martin Farms, Carroll's Foods of Virginia, the Virginia Department of Mines, Minerals and Energy, and DOE's Southeast RBEP collaboratively funded this demonstration project. The project is the first of its kind in Virginia and believed to be the first farm in the nation designed to incorporate an anaerobic digester from its inception. On average, about $80 \%$ of the farm's electrical energy needs are provided. Due to the nature of the lagoon system, electrical generation during the winter averages $15-\mathrm{kW}$ when the digester is fully functional. During the summer, electrical generation exceeds $25-\mathrm{kW}$. It is not anticipated that the project will ever produce more electricity than the Martin's farm will consume. The farm manure management system is based on hydraulic flushing and features 2 cells: the passive covered digester and a second storage lagoon. Initially, a heat exchange grid was installed on the bottom of the digester to act as the engine's radiator, and to use the waste heat to 
Maintenance History:

Lessons Learned: warm the lagoon during the winter. It was hoped that a warmer lagoon would increase biogas production during the cooler months and help reduce sludge accumulation. However, the mass of water in the lagoon was too great for the amount of heat recovered from the engine to provide much warmth. In 1996, the original XR-5 cover ripped and partially sank. During the late summer of 1997, a new cover made out of XR-5 based on a different design was installed. Although there have been some problems with the new cover design, it is expected to be fully validated by the end of 1998 .

Maintenance is a daily routine check of equipment that takes about 20 minutes. Although the biogas is scrubbed with an iron sponge before engine fueling, engine oil is changed every 300 hours.

Tears in the digester's cover skirts diluted the energy content of the biogas by allowing air to enter when the project was first started. Despite this problem, the covered lagoon has, to date, worked well and has required little maintenance. Given current herd size and energy offsets, capital costs need to be reduced by $25 \%$ or more to enhance economic performance. The main areas where savings could be achieved are the lagoon cover and the lagoon heat exchanger. Cover costs could be reduced by design modifications or materials cost. "It may prove more cost-effective not to have a lagoon heat exchanger...However, a system could be designed to utilize the waste heat from the engine to supply the farm's heat energy needs." The low level of winter biogas production makes its use somewhat problematic by an engine.
COSTING INFORMATION

Siting Cost: Included in capital cost.

Capital Cost:

Annual O\&M Cost:

End-Use of Biogas:

Prime Mover Type:

ANNUAL SAVINGS

Electricity Production:
$\$ 85,128^{1}$ was the original project cost. Replication costs are estimated to be $\$ 95,200$. $^{2}$

Not available, but estimated to be $\$ 2,500$.

Electricity with no thermal reclaim. In the fall of 1998, the farm will be converting to a hot water boiler.

25-kW model H225 Chrysler marine engine with a Kato generator.
Estimated at 150,000-175,000 kWh. 
Electricity Savings: $\quad$ Estimated at $\$ 10,625$. The 1998 energy charge is $\$ 0.065 / \mathrm{kWh}$, with no demand charge.

Thermal Production: Currently not applicable. When the new boiler system is installed it will be used to crate hot water for use by pig mats under farrowed pigs in the nursery area.

Thermal Savings: $\quad$ Currently not applicable, but if hot water were recovered it could offset around $\$ 6,000$ in propane expenses. ${ }^{2}$

End-Uses of Effluent: Digester effluent goes to the second-cell storage lagoon and is later recycled to flush the swine houses on a continuous cycle. Excess liquids from the second cell are land-applied.

Other System Savings: $\quad$ Significantly helps control odors and eliminates objections by neighbors.

$1^{\text {st }}$ Cover Designer: $\quad$ AgriWaste Technology, Inc.

Balance of System: $\quad$ Resource Conservation Management, Inc.

$2^{\text {nd }}$ Cover Designer: $\quad$ Resource Conservation Management, Inc. and Engineered Textile Products.

1. Gettier, S.; Roberts, M. (1994). Animal Lagoon Biogas Utilization System, Final Project Report. Muscle Shoals, AL: Southeastern Regional Biomass Energy Program. 23 pages.

2. Moser, M., et al. (1998). "Benefits, Costs and Operational Experience at Seven New Agricultural Anaerobic Digesters.” Proceedings of Bioenergy '98; October 4-8 1998; Madison, Wisconsin. Chicago, IL: Great Lakes Regional Biomass Energy Program. 
Case Study 4.16: $\quad$ Beltsville Agricultural Research Center

\begin{tabular}{ll}
\hline CONTACTS & Keith Hummel \\
\hline Address: & USDA Agricultural Research Service \\
& Beltsville Agricultural Research Center \\
& Research Animal Services Building 177C \\
& Beltsville, MD 20705
\end{tabular}

Telephone: $\quad 301.504 .9243$

GENERAL SYSTEM INFORMATION

Farm Type: Dairy.

Herd Size: $\quad$ System was designed for 450 total head with 225 milkers. 1998 herd size is 325 head with 150 milkers.

System Type: $\quad$ Slurry with vertical poured-concrete tank.

Dimensions: $\quad 28 \mathrm{ft} \times 30 \mathrm{ft}$ diameter.

Capacity: $\quad 19,800 \mathrm{ft}^{3}$ working volume $(148,000 \mathrm{gal})$.

Biogas Production: $\quad 13,000 \mathrm{ft}^{3} / \mathrm{d}(70 \%$ methane content).

1994.

1998 Status: $\quad$ Operational.

Project History: $\quad$ The project was initiated because of a desire to control odor at the new Dairy Research facility. Manure is pumped from a central collection pit to a solids separator. The separated solids having a moisture content of about $70 \%$ are sent to a composting bin for 3-4 weeks. The liquids are pumped to the digester and heated to about $100^{\circ} \mathrm{F}$ with a $20-23$ day HRT. About $40 \mathrm{ft}^{3} / \mathrm{cow} / \mathrm{d}$ of biogas is manufactured. After digestion, the liquids are transferred to a 1.8 million gal storage tank where they are held as long as 180 days. Minimal mechanical mixing of the digester contents occurs within the digester. Manure is mixed by thermal activity via hot water which is circulated throughout the digester by pipes embedded in the floor and an interior concrete wall. Milking center water is pumped for separate treatment at a wastewater treatment facility. 
Maintenance History: Daily O\&M requirements are minimal, taking 10-15 minutes on daily average. A consistent data collection protocol is followed to monitor system performance.

Lessons Learned: $\quad$ Not available.

COSTING INFORMATION

Siting Cost: Included in capital cost.

Capital Cost: $\quad \$ 500,000$, but this includes other costs associated with the farm's entire manure management handling system (storage tank, alley scrapers, etc.)

Annual O\&M Cost: $\quad$ Not available.

End-Use of Biogas: $\quad$ Thermal production used for heating digester, the balance is flared.

Prime Mover Type: $\quad$ Not available.

ANNUAL SAVINGS

Electricity Production: $\quad$ Not applicable.

Electricity Savings: $\quad$ Not applicable, but is was estimated that sufficient biogas was available to generate about $\$ 15,000$ worth of electricity annually.

Thermal Production: $\quad$ Not available.

Thermal Savings: $\quad$ Not available.

End-Uses of Effluent: $\quad$ It is estimated that more than 160 tons of dry, odor-free material will be produced that can be used as landscape media or as an organic growing media. Liquids are applied to fields either by soil injection or by irrigation.

Other System Savings: Odor control is a significant advantage because the digestion process nearly eliminates the volatile acids present in raw manure. Also, the process offers the chance to reduce water and methane pollution, and to reduce fly and insect populations.

Designer/Installer: Agway. 
Case Study 4.17: $\quad$ Craven Dairy Farms

\begin{tabular}{ll}
\hline CONTACTS & Jeff Craven \\
\hline Address: & 10395 Meda Dairy Road \\
& Cloverdale, Oregon 97112
\end{tabular}

Telephone: $\quad 503.392 .4555$

GENERAL SYSTEM INFORMATION

Farm Type: Dairy.

Herd Size:

750 total head, but uses the manure from 1,000 cows.

System Type: $\quad$ Plug-flow with polypropylene cover material.

Dimensions: $\quad 120 \mathrm{ft} \times 30 \mathrm{ft} \times 12 \mathrm{ft}$.

Capacity: $\quad 43,200 \mathrm{ft}^{3}$.

Biogas Production: $\quad 42,000 \mathrm{ft}^{3} / \mathrm{d}$ from 650 cows $^{1}$ ( $60 \%$ methane content).

1997.

1998 Status: $\quad$ Operational.

Project History: $\quad$ Craven Farms, the Oregon Department of Energy, and DOE's Pacific Northwest and Alaska RBEP collaboratively funded this demonstration project. The original purpose was to reduce fecal coliform discharges to local pasture lands from a herd of 800 cows. Later, the project was increased to accommodate the manure of 1,000 cows as the strategic growth requirements of the dairy industry became more apparent. As a result of increasing the digester size, the project became more profitable than originally projected because the local utility offered a higher buy-back rate and the owner was better able to take advantage of certain tax benefits. The digester is sized to operate at $100^{\circ} \mathrm{F}$ with an $11 \%-12 \%$ TS concentration and a 20 day HRT. Manure is collected by daily tractor scraping to a collection pit from where it is pumped into the digester. Until the herd expansion is complete, arrangements have been made to transport manure from other farms to increase electrical and fiber outputs.

Maintenance History: $\quad$ Normal daily maintenance takes about 5-15 minutes and consists of a visual inspection of the digester solids loading rate and checking 
engine/generator oil levels. It is expected that engine oil and filter changes will occur about every 200 operating hours.

Lessons Learned:

One cost containment strategy was to use current and pre-owned equipment to the greatest extent possible; however, some of it did not perform as expected. ${ }^{2}$ The manure pump failed to deliver the anticipated flow rate, which initially affected the digester's desired solids concentration. Both engines were replaced and both generators reconditioned. These factors raised capital cost more than was originally expected. However, the equipment is now functioning well and the farm is quite pleased with the project as built.

COSTING INFORMATION

Siting Cost:

$\$ 29,500$.

Capital Cost:

$\$ 217,950$.

Annual O\&M Cost:

Not available.

End-Use of Biogas:

Electricity production. A thermal reclaim system for milk house and parlor hot water heating will be completed later in 1998.

Prime Mover Type: $\quad$ Two 65-kW Ford model 460 engines. As of May 1997, with 650 cows contributing manure, there was sufficient biogas to generate an average continuous output of $85-\mathrm{kW}$. As the herd size increases, it is estimated that up to $120-\mathrm{kW}$ can be generated. ${ }^{2}$

ANNUAL SAVINGS

Electricity Production:

Not available.

Electricity Savings:

Estimated to be $\$ 24,000^{1}$ in 1998 . All power output is being sold to the local electricity supplier at a rate of $\$ 0.035 / \mathrm{kWh}$, while the farm purchases all their needs at rates averaging $\$ 0.028 / \mathrm{kWh}$.

Thermal Production: $\quad$ Now used for digester heating, but when the thermal reclaim system is installed it will displace $24-\mathrm{kW}$ in electric water heating.

Thermal Savings: Currently not applicable, but when the thermal reclaim system is installed it is estimated that it will save $\$ 3,500$ in water heating expenses.

End-Uses of Effluent: $\quad$ Liquids are pumped into existing storage ponds for later land application. Separated solids are to be used for freestall and calf barn bedding and also sold as potting soil amendments at $\$ 8.00 / \mathrm{yd}^{3}$ 
Other System Savings: $\quad$ Digested fiber sales are estimated to be $\$ 30,000 /$ year. ${ }^{1}$

Designer: $\quad$ Resource Conservation Management, Inc.

Installer: $\quad$ Craven Farms.

1. Moser, M., et al. (1998). "Benefits, Costs and Operational Experience at Seven New Agricultural Anaerobic Digesters.” Proceedings of Bioenergy '98; October 4-8 1998; Madison, Wisconsin. Chicago, IL: Great Lakes Regional Biomass Energy Program.

2. Mattocks, R. (1997). Craven Farms Dairy Manure Digester, Interim Report. Seattle, WA: Pacific Northwest and Alaska Bioenergy Program. 3 pp. 


\section{Case Study 4.18: $\quad$ Barham Farms}

\begin{tabular}{ll}
\hline CONTACTS & Julian Barham \\
\hline Address: & 10518 Covered Bridge Road \\
& Zebulon, NC 27597
\end{tabular}

Telephone: $\quad 919.365 .8400$

GENERAL SYSTEM INFORMATION

Farm Type: Swine (farrow-to-wean).

Herd Size: $\quad 8800$ total head with 4000 sows.

System Type: $\quad$ Covered lagoon

Permalon cover material initially.

HDPE replacement.

Dimensions:

$264 \mathrm{ft} \times 264 \mathrm{ft} \times 20 \mathrm{ft}$.

Capacity:

$1,394,000 \mathrm{ft}^{3}$ (10.4 million gal).

Biogas Production:

$50,000 \mathrm{ft}^{3} / \mathrm{d}$ summer average and $36,000 \mathrm{ft}^{3} / \mathrm{d}$ winter average projected $^{1}$ (methane content not provided). During summer 1997 , produced $31,000 \mathrm{ft}^{3} / \mathrm{d}$ (70\%-75\% methane content). Producing $28,000 \mathrm{ft}^{3} / \mathrm{d}$ in summer 1998 .

Operational Date: $\quad$ First cover installed in February 1997.

Second cover installed in July 1997.

Third cover installed in June 1998.

1998 Status: $\quad$ Operational.

Project History: $\quad$ In 1995, 1 year after the farm opened, the operator became interested in innovative strategies to reduce odors, improve water quality, and manage energy costs. The AgSTAR program was contacted, which led to a feasibility study and the decision to participate as a showcase of improved manure management systems. The farm manure management system uses a pit-recharge hydraulic flushing that generates $1 \%-2 \%$ TS and a 60-65 day HRT. The project is likely the first in the nation to be designed using the NRCS interim standard 360, Covered Anaerobic Lagoon. System design included the provision of a clay-lined lagoon with a loading rate of $9.5 \mathrm{lb}$ $\mathrm{VS} / 1000 \mathrm{ft}^{3}$ of volume. ${ }^{2}$ The manure management system also has a 
Maintenance History: A daily routine check of equipment that takes about 20 minutes.

Lessons Learned:

second lagoon used for storage. The system initially featured an innovative cover and piping system that had 4 separate floating modules, rather than the single cover used on earlier designs. The digester's first cover delaminated in the early summer of 1997 and was replaced under warranty. A second cover was installed, which also failed. In the summer of 1998, a different design was developed, which is a total lagoon "bank-to-bank" system and uses HDPE cover material.

As already noted, startup problems were encountered with the covers and gas recovery system. However, the biggest problem was matching biogas production to electricity generation in the first summer while the digester was achieving its "steady-state." The generator system is induction based. As a result, the lower level of biogas production was insufficient to power the engine except for a few hundred hours of test operation during 1997. The engine is being operated at a level of around 90-kW during daytime peak-load hours. A boiler is used during off-peak hours to provide hot water for pig mats under farrowed pigs.

COSTING INFORMATION

Siting Cost:

Capital Cost:

Annual O\&M Cost:

End-Use of Biogas:

Prime Mover Type:

ANNUAL SAVINGS

Electricity Production:

Electricity Savings:

Thermal Production:
$\$ 25,000$ (AgSTAR).

$\$ 264,474^{4}$ although some farm labor is not included in this estimate.

Not available.

Electricity generation with thermal reclaim. Also has separate boiler system installed.

Model 3406 Caterpillar coupled to a 120-kW generator.
Not available, but likely to be $325,000-355,000 \mathrm{kWh}$.

Estimated at $\$ 35,000$. The farm will enter into a sales agreement with the local electricity suppler to sell any surplus electricity.

Not available, but likely 1.2 million Btu are recovered. Heat from the boiler and waste heat captured from the engine are stored in a 10,000 gal hot water storage tank for year-round use in heating the farrowing buildings. 
Thermal Savings: $\quad$ Estimated to be $\$ 11,000$ in offset propane. ${ }^{2}$

End-Uses of Effluent: $\quad$ Digester effluent goes to the second storage lagoon before used to irrigate cropland. Strongly considering installing an attached greenhouse to produce hydroponic vegetables such as tomatoes. This would require that the digester effluent would be sterilized before use as a nutrient source.

Other System Savings: $\quad$ Significant help in controlling odors. "Would be a good investment just to cover and flare solely for odor control and water quality benefits."

$1^{\text {st }}$ Cover designer: $\quad$ Resource Conservation Management, Inc.

$2^{\text {nd }}$ Cover designer: $\quad$ Environmental Fabrics, Inc.

Balance of System: $\quad$ Power Energy Systems, Inc.

1. Moser, M., et al. (1997). "AgSTAR Program: Three Commercial-Scale Anaerobic Digester Systems for Animal Waste." Proceedings of the $3^{\text {rd }}$ Biomass Conference of the Americas; August 24-29, 1997; Montréal, Québec, Canada. New York: Elsevier Science; pp. 1221-1228.

2. U.S. Environmental Protection Agency. (1997) AgSTAR Handbook: A Manual for Developing Biogas Systems at Commercial Farms in the United States. Washington, DC; EPA-430-B-97-015.

3. Saele, L. (1997) Barham Hog Farm: Improving Waste Management Through AgSTAR! NRCS Newsletter (6) .

4. Moser, M., et al. (1998). "Benefits, Costs and Operational Experience at Seven New Agricultural Anaerobic Digesters.” Proceedings of Bioenergy '98; October 4-8 1998; Madison, Wisconsin. Chicago, IL: Great Lakes Regional Biomass Energy Program. 
Case Study 4.19: $\quad$ Cushman Dairy

\begin{tabular}{ll}
\hline CONTACTS & Nathan Cushman \\
\hline Address: & 120 Kahn Road \\
& North Franklin, CT 06254
\end{tabular}

Telephone: $\quad 860.642 .4711$

GENERAL SYSTEM INFORMATION

Farm Type: Dairy.

Herd Size: $\quad 600$ milkers (May increase to 900 milkers in 2-3 years).

System Type: $\quad$ Complete-mixed with metal tank having a cone-shaped bottom.

Dimensions: $\quad 38 \mathrm{ft}$ x $31 \mathrm{ft}$ diameter.

Capacity: $\quad 29,300 \mathrm{ft}^{3}$ working volume $(219,000$ gal).

Biogas Production: $\quad 40,000-45,000 \mathrm{ft}^{3} / \mathrm{d}(60 \%$ methane content).

1997.

1998 Status: $\quad$ Operational.

Project History: $\quad$ The digester was installed for odor control and nutrient management reasons. A grant from the state Department of Agriculture was used to help buy down system capital costs. After reviewing digester options, the operator decided to construct a mixed tank system because of comfort level with technology. Given the other options, a mixed tank was viewed as having greater flexibility for the future not seemingly offered by the other options. A mixed tank system offers the chance to use surplus heat to increase the operating temperature of the digester to the thermophilic range. This would provide the ability to significantly increase herd size without major system modifications. The digester currently operates at $103^{\circ} \mathrm{F}$ with a $9 \%$ TS concentration and a 12-15 day HRT.

Maintenance History: $\quad$ Not available.

Lessons Learned: $\quad$ The project is based on net metering, a utility concept in which the meter can run backward if surplus power is produced. Because of the project size, an intertie agreement was able to move forward 
quickly without a formal contract with the local electric supplier. The operator would have liked to have done a better job with capital budgeting, but found it difficult to plan exactly. Some costs were known, but others were hard to pin down. The moving of the digester site to another area on the farm might have been considered since the current location required running a new electrical service line, which cost an additional \$18,000. All in all, the experience to date has been a happy one.

COSTING INFORMATION

Siting Cost:

Capital Cost:

Annual O\&M Cost:

End-Use of Biogas:

Prime Mover Type:
Included in capital cost.

$\$ 450,000$.

\$10,000-\$12,000 (planned).

Electricity production to offset purchased power. Can sell surplus back to the utility.

Primary: Ford 6005 80-kW with Kohler generator.

Secondary: Ford 6003A 40-kW with Kohler generator (used for digester's electrical requirements).
ANNUAL SAVINGS

Energy Production:

Energy Offsets:

Thermal Production:

End-Uses of Effluent:

Other System Savings:

Designer/Installer:
Projected to average between $425,000-500,000 \mathrm{kWh}$.

Projected to be $\$ 40,000-\$ 48,000$ at the 1998 electricity price of $\$ 0.096 / \mathrm{kWh}$. Surplus can be sold back at a cost of $\$ 0.029 / \mathrm{kWh}$.

Used for digester heating only.

Digester effluent is stored for later land application. Offsetting purchased bedding with digested solids is estimated to save $\$ 12,000$. Excess solids are sold as compost at $\$ 8.00 / \mathrm{yd}^{3}$, which could provide revenues of as much as $\$ 2,000 /$ month.

Labor savings resulting from reduced amount of land spreading. System gives flexibility to increase herd size because of odor control benefits. Digester will not be a financial drag on farm resources.

Agri-Biosystems, Inc. 
Case Study 4.20: $\quad$ Freund Dairy

\begin{tabular}{ll}
\hline CONTACTS & Matt Freund \\
\hline Address: & 324 Norfolk Road (State Road 44) \\
& East Cannan, CT 06024
\end{tabular}

Telephone: $\quad 860.824 .0266$

GENERAL SYSTEM INFORMATION

Farm Type: Dairy.

Herd Size:

350 head with the manure from 200 milkers used.

System Type:

Horseshoe-shape slurry with hypalon cover material.

Dimensions:

$62 \mathrm{ft} \times 14 \mathrm{ft} \times 8 \mathrm{ft} \times 2$ sides.

Capacity:

$13,800 \mathrm{ft}^{3}(108,400 \mathrm{gal})$

Biogas Production:

$14,000 \mathrm{ft}^{3} / \mathrm{d}$ in the winter and $4,000 \mathrm{ft}^{3} / \mathrm{d}$ during summer pasturing.

Operational Date:

1997.

1998 Status:

Operational.

Project History:

The digester was installed to increase the manure handling efficiency. The system permits liquid manure handling throughout the year, especially during the cold winter months. A specific farm objective is to be able to separate fiber from manure in the winter months and store the liquid filtrate for irrigation. Odor control was not an issue. The farm has already implemented a demand-side management strategy to reduce energy bills, and has explored using a number of renewable energy resources. A grant from the state Department of Agriculture was used to help buy-down system capital costs. During the winter, the digester operates at $100^{\circ} \mathrm{F}$ at a $11 \%-13 \%$ TS concentration and a 20-day HRT. Because cows are pastured in the summer months, considerably less manure is collected, which results in a longer and more variable HRT.

Maintenance History: $\quad$ Normal daily maintenance takes about 15 minutes and consists of a visual inspection of the digester and the boiler system. However, during startup maintenance and system tuning sometimes took all day. Although informed and expecting a period of intensive learning 
Lessons Learned:

on how to operate the system, because of decisions to minimize some equipment purchases, start-up was " 6 months of hell."

The main project drawback was a lack of practical information about what other farmers had done in the digestion area. Would have spent more time gathering background information, especially on failed systems. Would liked to have had a better discussion on the pitfalls and payoffs of various design options. Would also have been more skeptical of some information that was provided in the design phase. For example, tried to install a gravity-fed influent collection tank to save on the cost of a mixer if it were found not to be necessary. After many hours of trying to make the passive system work, eventually added a mixer to the collection vessel at a cost of $\$ 5,000$. It would have been less expensive and much less of a hassle to install the mixer initially. Additionally, there are certain times of the year when some materials simply do not pump.

COSTING INFORMATION

Siting Cost: $\$ 24,000$ (AgSTAR).

Capital Cost:

$\$ 125,000$, which included the digester, solids separating system, lined storage lagoon, and ancillary equipment. Digester component of project was estimated to cost $\$ 64,000$.

Annual O\&M Cost: $\quad$ Estimated at $\$ 1,500$.

End-Use of Biogas: $\quad$ Digester heating and heating the farmhouse and nearby greenhouses.

Prime Mover Type: $\quad$ Modified 400,000 Btu/hour Burnham boiler.

ANNUAL SAVINGS

Thermal Production: Not available.

Thermal Savings: $\quad$ Estimated at $\$ 10,400$ after digester heating requirements are met.

End-Uses of Effluent: $\quad$ Liquids are pumped into an irrigation line and land applied yearround. Separated fiber is used for freestall and calf barn bedding, replacing sawdust bedding estimated to cost $\$ 7,000$ annually. Would like to develop value-added products from separated fiber.

Other System Savings: $\quad$ Many small modifications still required to get system fully functional, but overall "very happy with the digestion system."

Designer: $\quad$ Resource Conservation Management, Inc.

Installer: $\quad$ Freund Dairy. 
Case Study 4.21: $\quad$ AA Dairy

\begin{tabular}{ll}
\hline CONTACTS & Bob Aman \\
\hline Address: & 58 Footes Crossing \\
& Candor, NY 13743
\end{tabular}

Telephone: $\quad 607.659 .3200$

GENERAL SYSTEM INFORMATION

Farm Type: Dairy.

Herd Size: $\quad$ Although the digester is sized for 1,000 milkers, the 1998 herd size is 500 milkers. Will be using system benefits to expand the milking herd to 1,000 cows in the near future.

System Type: $\quad$ Plug-flow with hypalon cover material.

Dimensions: $\quad 130 \mathrm{ft} \times 30 \mathrm{ft} \times 12.5 \mathrm{ft}$.

Capacity: $\quad 48,400 \mathrm{ft}^{3}(362,000$ gal $)$.

Biogas Production: $\quad 42,000 \mathrm{ft}^{3} / \mathrm{d}^{1}$

Operational Date: 1998.

1998 Status: $\quad$ Operational.

Project History: $\quad$ Interest in AD began in the late-1970s during the energy crisis. However, the farm was much smaller. As the herd size increased, the new farm was designed from the beginning to have a digestion system as a key component to the farm's entire manure management system. The perspective changed to allow growth in herd size while also controlling odor and water quality. In addition to the digester and related components, the upgrade also included a 2.4 million gal lined storage pond, 5 miles of irrigation line, an irrigation pump, and applicator. ${ }^{1}$ Because AD systems are an approved BMP in New York, the project was able to take advantage of grant from the local Soil and Water Conservation District. Including the cost of the lined storage lagoon, the grant covered about one-third of the total project cost.

Maintenance History: $\quad$ Normal maintenance consists of a visual inspection of the digester solids loading rate and engine/generator oil levels. The biogas is not 
scrubbed before combustion. The engine is run continuously, except for scheduled oil changes every 200 hours. Spent oil is sent to a laboratory for analysis, and the length of time between engine oil changes could increase as the system gathers operational history.

Lessons Learned: $\quad$ If more had been known about the subject, some basic design setups would have been changed to save some money. One of these would have been siting the engine closer to the power pole for utility hookup. The current engine site required running $265 \mathrm{ft}$ of 3-phase power cable that cost $\$ 8,000$.

COSTING INFORMATION

Siting Cost:

Capital Cost:

Annual O\&M Cost:

End-Use of Biogas:

Prime Mover Type: $\$ 29,500$ (AgSTAR).

$\$ 211,800^{2}$, which included the digester, engine/generator, solids separating system, and ancillary equipment. The lined storage pond, 5 miles of irrigation line, an irrigation pump and applicator cost an additional $\$ 102,000$.

Estimated $^{1}$ at $\$ 15,000$.

Electricity production. Will develop thermal reclaim option when most efficient use for it is found.

130-kW model 3306 Caterpillar engine, which operates at a load displacement level of 75-kW with 500 milkers.

\footnotetext{
Electricity Production: $\quad$ Using the manure from 500 dairy cows could produce 430,000-

ANNUAL SAVINGS $455,000 \mathrm{kWh}$.

Electricity Savings: $\quad$ When the digester reaches full capacity is estimated that $\$ 30,000$ in electricity costs will be offset, reducing purchased power to around $\$ 6,000$ annually. The current farm electric bill averages about $\$ 36,000-\$ 42,000 /$ year at an energy charge of $\$ 0.09 / \mathrm{kWh}$. Any surplus electricity generated will be sold to the local utility at a rate of $\$ 0.02 / \mathrm{kWh}$.

Thermal Production: $\quad$ Not available.

Thermal Savings:

$\$ 3,500$ design estimate. ${ }^{2}$

End-Uses of Effluent: "The effluent leaving the digester is $6.7 \%$ solids. It is pumped to a screw press separator...(designed to)...handle about 2 cows daily manure production per minute. The separator does seem to work
} 
better with digested manure than with raw manure."1 Liquids will eventually be pumped into an irrigation line and land applied on crops. It is expected that no fertilizers will be required except as a starter. It is likely that there will be a time when no commercial fertilizers are used. Separated solids are sold to a bulk amendment processor for $\$ 8.00-\$ 10.00 / \mathrm{yd}^{3}$. Manure solids sales could generate between $\$ 20,000-\$ 25,000 /$ year with 500 milkers.

Other System Savings: $\quad$ Significant unquantified benefits from odor control. "Building for the future."

Designer: $\quad$ Resource Conservation Management, Inc.

Installer: $\quad$ AA Dairy.

1. Wright, P.; Perschke, S. (1998) "Anaerobic Digestion and Wetland Treatment Case Study: Comparing Two Odor Control Systems for Dairy Farms.” ASAE Paper No. 984105. Presented at the 1998 ASAE Annual International Meeting, Orlando, FL, 12-16 July [1998].

2. Moser, M., et al. (1998). "Benefits, Costs and Operational Experience at Seven New Agricultural Anaerobic Digesters." Proceedings of Bioenergy '98; October 4-8 1998; Madison, Wisconsin. Chicago, IL: Great Lakes Regional Biomass Energy Program. 
Case Study 4.22: $\quad$ Kirk Carrell Dairy

\begin{tabular}{ll}
\hline CONTACTS & Kirk Carrell \\
\hline Address: & 10502 County Road 913 \\
& Godley, TX 76044
\end{tabular}

Telephone: $\quad 817.389 .3552$

GENERAL SYSTEM INFORMATION

Farm Type: Dairy.

Herd Size:

580 total head with manure from 400 milkers used.

System Type: $\quad$ Plug-flow.

Dimensions: $\quad 104 \mathrm{ft} \times 18 \mathrm{ft} \times 8 \mathrm{ft}$ (12 ft at "V" bottom).

Capacity: $\quad 14,700 \mathrm{ft}^{3}$ working volume $(110,000$ gal).

Biogas Production: $\quad 20,000 \mathrm{ft}^{3} / \mathrm{d}$ projected (60\% methane content).

Operational Date: $\quad$ Fall 1998.

1998 Status: $\quad$ Under construction.

Project History: $\quad$ The project was originally built in 1985. Biogas production and other operating difficulties led to it being shut-down within a year of its startup. In 1995, the Texas Agricultural Experiment Station began to renovate the system as a demonstration of technology for treating dairy manures. "The challenge for the renovation project has been to identify shortcomings in the original design and develop modifications to overcome these."1 In addition to providing power for the dairy, the renovated system was undertaken to reduce the potential for water pollution. The original digester consisted of the concrete tank, a rubber/fabric gas bag collection system, and a metal building constructed over the gas bag for its protection. This was replaced with a lightweight reinforced concrete plank cover over a Hypalon membrane to collect the gas. This revised system has the potential for a longer life than the original and, also, allows for easier access to the digester for system monitoring. The digester is designed to operate at $100^{\circ} \mathrm{F}$ with a $4 \%-5 \%$ TS concentration and a 10-day HRT. 
Maintenance History: $\quad$ Not available. To reduce the potential for engine damage from hydrogen sulfides and other contaminants in the biogas, a scrubber was installed. The scrubber is an in-line molecular sieve cartridge filter. Replacement cartridges are relatively inexpensive (\$100) and are easy to install.

Lessons Learned: $\quad$ Not available.

COSTING INFORMATION

Siting Cost:

Capital Cost:

Annual O\&M Cost:

End-Use of Biogas:

Prime Mover Type:

ANNUAL SAVINGS

Electricity Production:

Electricity Savings:

Thermal Production:

End-Uses of Effluent:

Other System Savings:

Rehab Designer:

Cady Engler, Texas A\&M University.

Cover Installer:

Only used for digester heating.
Not available.

$\$ 100,000$ was spent to rehabilitate the system. However, this included the cost of monitoring instrumentation that would not normally be associated with such a project. Basically everything from the original system except the concrete tank was scrapped.

Not available, but based on the projected level of electricity production should be $\$ 4,000-\$ 5,000$.

Electricity production.

Chevrolet 454 cubic inch industrial engine and a $60-\mathrm{kW}$ generator.

Not available, but estimated to be 250,000-275,000 kWh. Should be sufficient to provide the electricity needs of the dairy.

Not available, but estimated to be $\$ 12,500-\$ 14,000$. The system operates on a stand-alone displacement basis that will not sell excess electricity to the utility. Excess biogas will be flared.

Effluent is pumped to a lagoon and later reused for flush water.

1. Engler, C.; McFarland, J. (1997). Dairy Manure Research and Demonstration Project. 6 pages. College Station, TX: Texas A\&M University. 
Case Study 4.23: $\quad$ BTI-Noble Fertilizer Production Facility

\begin{tabular}{lll|}
\hline CONTACTS & Dr. Renato E. Lumbroso & \\
\hline Address: & $\begin{array}{l}\text { BioRecycling Technologies, Inc. } \\
\text { 6101 Cherry Avenue } \\
\text { Fontana, CA 92336 }\end{array}$ & $\begin{array}{l}\text { BTI-Noble } \\
\text { 18559 W. Lincoln Avenue } \\
\end{array}$ \\
Kerman, CA 93630 \\
Telephone: & 909.899 .2982 & 209.846 .7601 \\
FAX: & 909.899 .9519 & \\
\hline GENERAL SYSTEM INFORMATION & \\
\hline
\end{tabular}

Farm Type: $\quad$ Not applicable (centralized system).

Herd Size: $\quad 10,000$ total head of dairy cows.

System Type: $\quad$ Complete-mix with metal tanks, configured as two-stage mixed thermophilic reactors.

Dimensions: $\quad 10$ tanks, each measuring $28 \mathrm{ft}$ by $19 \mathrm{ft}$ in diameter .

Capacity: $\quad 530,000$ gal.

Biogas Production: $\quad 300,000 \mathrm{ft}^{3} / \mathrm{d}$ projected $(58 \%-60 \%$ methane content target).

Operational Date: December 1998.

1998 Status: $\quad$ Under construction.

Project History: $\quad$ The BTI production plan is based on the daily delivery of fresh manure produced from about 10,000 dairy cows. It is estimated that there are 80-90 dairies within a 30-mile radius of the site. Third-party contractors under contract to BTI will collect the manure daily from dairy farms in the vicinity of the site. On average, approximately 10 truckloads of fresh manure will be entering the plant over a 10-hour period from Monday-Saturday. The manure will be tested for quality before to being delivered to a receiving tank. The manure feedstock in the receiving tanks will then be diluted and homogenized with water and then pumped to the primary digesters.

After a certain HRT, digested "slurry" is discharged and collected in another tank and fresh manure is added to each primary digester. The digested "slurry" will then be sent to a building where 
separators divert the solid fibrous fraction and the liquid fraction. The solid fibrous fraction will be transported to a secondary processing area of the site where it will be stored in windrows for further aerobic processing to attain the specifications for its intended end-product. The windrows are constantly monitored to ensure proper maturation. After maturation, the composted product is bagged or hauled off-site.

After separation, the primary digesters create a liquid fraction that can be redigested with fresh manure or piped to centrifuges for further separation. The centrifuges will produce a liquid called "centrate" and a solid material called "cake." The centrifuged "cake" is transported to the pelletizing process building to be blended with other products and manufactured into NutriPellets, a dry, high-grade fertilizer about the size of a very small ball bearing. The pelletized product is then bagged.

The liquid centrate is pumped from the centrifuges into secondary digesters, where the liquid is further digested into biogas and a final digested liquid through a second-stage continuous AD process conducted at a lower temperature than the primary digestion. The digested liquid can then be shipped for use as liquid organic fertilizer. Some of the digested centrate is piped to stabilization tanks. There, the centrate is stabilized by lowering the $\mathrm{pH}$ through the addition of one or more mineral acids, and may be fortified to create a controlled formula family of products called NutriPlus.

The biogas generated from the primary digesters, the slurry tanks, and the secondary digesters is combined and piped to the cogeneration system. That portion of electrical energy that is not used on site will be sold to the local utility or nearby property owners for use at market rates. A thermal recovery system, which is integrated into the exhaust of the engine, recovers the heat for use within the facility, principally to heat the manure feedstock and the primary digesters. A standby flare will be used to burn off biogas if a malfunction prevents it from being combusted in the cogeneration system.

Maintenance History: $\quad$ Not applicable.

Lessons Learned: Not available. 
COSTING INFORMATION

Siting Cost: Not available.

Capital Cost: $\quad \$ 5.5$ million.

Annual O\&M Cost: $\quad$ Not available.

End-Use of Biogas: $\quad$ Electricity generation with thermal recovery for heating digester, drying finished products, and other process requirements.

Prime Mover Type: $\quad$ Not available, but will be a lean-burn internal combustion engine.

ANNUAL SAVINGS

Electricity Production:

Electricity Savings:

Thermal Production:

Thermal Savings:

End Uses of Effluent:

Other System Savings:

Designer:

Installer:
Not available, but prime mover to have a rated capacity of 1050$\mathrm{mW}$.

Up to $450-\mathrm{kW}$ to be used for internal load, the balance of electricity will be sold as "green" power.

4.3 million Btu/hour.

Not applicable.

See Case Study 4-12 on the BTI-Gonzales operation.

See Case Study 4-12 on the BTI-Gonzales operation.

BioRecycling Technologies, Inc.

The Industrial Company (TIC). 


\subsection{Summary of Case Studies}

The AD process is biologically based; therefore, it must be evaluated and implemented at each site. As a result, few meaningful generalizations can be made. Factors required for successful project implementation include: an adequate match of digester type to the farm's manure management program, competent design, and installation, which simplify digester O\&M, maximization of coproduct use to enhance economic performance, and, overall, an accommodating farm management and its willingness to incorporate the uncertainties of a new technology.

The list of reasons explaining why some AD projects fail must be headed by bad design or installation. When selecting the "best" qualified contractor to design or install an anaerobic digester system, an investor should rarely consider a firm without a significant amount of practical experience in the field. Poor equipment and materials selection is the second most common reason digesters fail. Although buying the best and most expensive equipment and materials available cannot guarantee project success, amortizing the cost of quality components over the life cycle of the project is a far better prospect than experiencing a failure resulting from the use of inferior products. The third reason is related to farm management. Even the best designed and installed digester made of quality components will fail in the hands of the "wrong" farm. The phrase best used here is that the operator needs to be "screwdriver friendly."

Excluding institutional factors (e.g., the farm was sold or closed, owner health) some of the primary causes of farm-based digester failure include: ${ }^{1,2}$

"Shut down due to an inability to heat digester to desired level."

"Design problems; insufficient insulation and agitation; grit deposition; engine hydrogen sulfide corrosion."

"Insufficient gas production due to build-up of straw and foam."

"Eccentric design used unproven materials and concepts."

"Screening and sedimentation process inadequate; too many pumps; needs new generator and separator screen; hay from cow dirt clogs pumps; wind damage to digester cover."

"Engine overheating; $20 \%$ down-time in first 2.5 years; engine rebuilt; valve and pump problems; excess foaming and overflowing; manure freeze-up; power generation under design figures."

"Shut down because of maintenance problems; repairs regarded as too expensive."

1 Ashworth, J. (1985). Universe of US Commercial-Scale Anaerobic Digesters: Results of SERI/ARD Data Collection. Golden, CO: Solar Energy Research Institute. Work performed by Associates in Rural Development, Inc., Burlington, VT.

2 ICF Consulting Associates (1992). U.S. Anaerobic Farm Digester Study. Unpublished report prepared for the U.S. Environmental Protection Agency, Washington, DC. 
"Severe gas leak; concrete cover cracked; 4 90-degree pipe elbows caused plugged lines; sawdust and manure formed scum layer."

"Never produced enough gas to generate electricity; manure not rich enough for gas production to reach desired level."

"Plugging problems; digester operated periodically for 1 year."

"Cost overruns; commercial belt press does not dry solids adequately for bedding."

"Shut down because of engine malfunction."

"Start-up problems; debris plugged bedding equipment; soap in digester."

"Shut down due to poor maintenance; level of hydrogen sulfide requires additional scrubber; digester too small to service number of cows on farm."

"Digester design impractical for northern climates; sulfide scrubbing/removal problem; large fluctuation in digester efficiency due to different management over operational life."

"Shut down because of lack of use for gas; owner did not want to just vent gas."

"Breach of contract dispute between designer and installer."

"Digester never became operational at optimal level because of problems in creating desired $\mathrm{pH}$ balance."

"Floor that supported digester exploded; project abandoned."

"Shut down after 2 months because of straw build-up; chopper pump installed too late; builder went out of business shortly after digester installed and owner left with inoperative digester."

"Hydrogen sulfide corrosion in engine; plugging problems; owner cannot spend required time to repair and manage digester."

"Shut down because of a lack of funding and amount of time required for doing maintenance."

"System too small for farm; hydrogen sulfide corrosion."

"Shut down attributed to 3 factors: inability to filter hydrogen sulfide caused gas compressor failure; lack of community support and too much biogas consumed in heating digester and could not generate enough electricity. Project was a 'disaster'."

"Shut down because economically inefficient; might have been better if less biogas was used to heat digester; experienced problems in obtaining desired $\mathrm{pH}$ balance." 
"Manure freeze-up; computer-controlled pressure and flame flare outlets did not function properly; insufficient gas production for feedstock volume."

"Poor design and pump problems in manure handling system; management problems forced shut down"

"Sand build-up in tank forced several cleanings; odor problem; escalating problems combined with falling commodity prices forced digester shut down."

To be merciful to the current designers of $\mathrm{AD}$ systems, many bad designs of old were caused by well-intentioned people early in the evolution of the industry. Most designs were borrowed from other waste treatment practices without giving adequate consideration to the unique characteristics of animal manures. Among other factors, these characteristics include: corrosiveness, abrasive fibers, grit, and a higher viscosity. As one scientist relates it, until now a digester operator has been akin to a "Model T" owner; we are now moving into the 1950s and 1960s of reliability, but not yet the 1990s of efficiency and use. 


\subsection{AND WHAT OF THE FUTURE?}

The conversion of agricultural wastes, animal manures in particular, into a renewable energy resource has been the focus of intensive research for more than two decades. Much has been learned about how manure can be used as an energy and nutrient source. Several available digester systems are both cost-effective and easily managed; however, the American farmer has not been motivated to adopt these new practices. More cost-effective and easily managed manure management techniques are still needed, especially for smaller farms, to encourage the farmer's use of animal waste for energy and nutrients.

Not only will farmers benefit monetarily, the use of AD will also help mitigate animal manure's contribution to air, surface, and groundwater pollution. There are additional indirect benefits for sustainable rural economic development from the implicit multiplier effect resulting from the direct jobs that can be created by providing, installing, and maintaining the digester system equipment. The implicit multiplier effect of integrated agricultural production and processing can be 2-3 times traditional production-only values.

Current developments in applied R\&D could provide some very exciting advances in AD technology for use on the farm. One R\&D project in Florida uses an anaerobic filter digester to treat flushed dairy manure. "Current liquid dairy waste management Pilot-scale anaerobic filter at the University of Florida (photo credit: Ann C. Wilkie) practices in Florida use short-term holding ponds for flushed manure wastewater storage with subsequent pumping to sprayfields to supply fertilizer nutrients and irrigation water for the production of forage crops. For economic reasons, sufficiently large storage facilities are not feasible and the holding time is on the order of three days. Such a practice allows anaerobic decomposition to begin, yet just as the odorous intermediate products accumulate the waste is

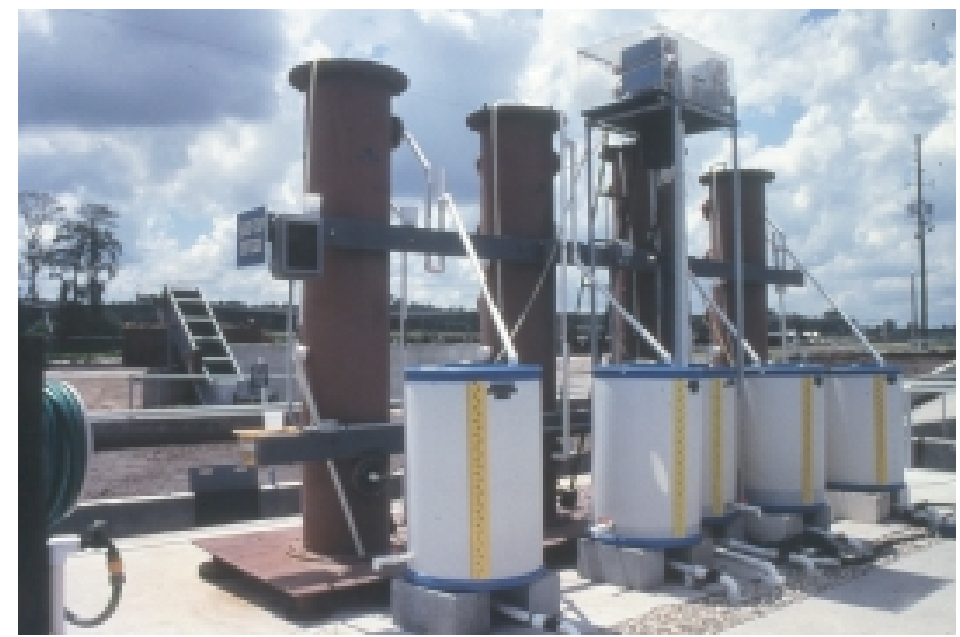
sprayed onto cropland, thereby volatilizing the odorous compounds and creating a high nuisance potential."1 As noted in Section 2.2, efforts at using an engineered lagoon and cover are an advancement in controlling odors and capturing biogas for productive use, but because of the large volume required may not always be a solution because of shallow water tables or other reasons.

\footnotetext{
${ }^{1}$ Wilkie, A.C. (1998). “Anaerobic Digestion of Livestock Wastes: A Suitable Approach to Odor Abatement.” The North Carolina 1998 Pork Conference and Beef Symposium; Raleigh, North Carolina. Raleigh, NC: North Carolina Pork Council; pp. 5-16.
} 
The anaerobic filter (fixed-film/packed-bed) was commercialized for industrial wastewaters in the late 1980s and, as the name implies, relies on packing material (media) to retain the biomass in the reactor vessel. Filter media are usually made from ceramics, glass, plastic, or wood. These filters are operated either in an upflow mode or in the less common downflow mode, depending on the manufacturer. The retention time for this "higher" rate digestion technology usually is typically 1-3 days, depending on the wastewater characteristics.

Other types of anaerobic digesters discussed for farm application, but not yet commercially used in the United States, include a variety of systems originally developed for industry as well, such as upflow sludge blankets and sequencing batch reactors. Although these technologies offer the potential for reducing the HRT required for the anaerobic process, they are perceived to suffer comparatively from higher capital and operating costs, as well as a greater level of process and operational complexity than the types now in operation.

On the verge of a breakthrough, one company ${ }^{2}$ is commercializing the anaerobic sequencing batch reactor (ASBR) system originally developed at Iowa State University. The company hopes to develop a system that is marketed to swine farms as an effective and reliable alternative to conventional lagoon systems. An ASBR system can have a significant advantage over lagoon systems from a perspective of odor control and space (volume) efficiency, and allows for a substantial reduction in BOD (as high as $92 \%$ removal). Although these types of systems are widely used by industry, the market conditions of farm-based operations have caused a lag in technology deployment. This group has two demonstration projects under way: one in Colorado, the other in Iowa. An ASBR system offers great flexibility in treating organic residues by handling wastewaters that can be high in solids and oxygen-demanding substances, as well as relatively weak waste streams such as domestic sewage. In an ASBR, wastes are fed periodically, from four to eight times each day. After each feeding, the digester cycles through four phases: feed, react, settle, and decant.

One other company ${ }^{3}$ is beginning to commercialize a multi-stage AD system. Multi-stage systems are based on the concept that by separating the hydrolytic, acidogenic, and methanogenic phases of the digestion process, bacteria can be converted more efficiently at each phase and with a shorter retention time. This should theoretically produce higher levels and concentrations of biogas from any feedstock. Because waste volumes can be minimized, greater cost-effectiveness should be the result. This operation has been tested extensively at a pilot plant in Chicago, and the first commercial demonstration is scheduled to be constructed on a dairy farm in Wisconsin.

Another project in California ${ }^{4}$ uses Advanced Integrated Ponding Systems (AIPS ${ }^{\mathrm{TM}}$ ). AIPS use a submerged canopy in a facultative pond where the organic wastes are completely converted into methane, nitrogen, carbon dioxide, and stable residues. The submerged canopy may be more costeffective than conventional covered lagoons because it is not exposed to weather and other

\footnotetext{
${ }^{2}$ Urell, R. (9 February 1998). Personal communication. ENTEK Biosystems, LLC, Peosta, IA.

${ }^{3}$ Newton, S. (12 February 1998). Personal communication. Commercial Engineering Corporation, Chicago, IL.

${ }^{4}$ Green, B. (28 April 1997). Personal communication. University of California, Berkeley, CA.
} 
elements. One intriguing aspect of AIPS is that the digester effluent is discharged into secondary pools and expressly used as a growth culture for algae. This approach offers a much more complete solution for carbon dioxide sequestration and nutrient removal.

There are even explorations into processes that combine the use of a reverse osmosis (RO) plant to treat discharged digester effluent. The pores of a RO membrane are so small that heterogeneous material is retained and only water molecules are allowed to pass. The result is a clean water fraction and a commercial standard fertilizer concentrated to about $10 \%$ of the original effluent volume.

Promising future waste-to-profit activities may enhance the economic performance of the overall farm manure management system. New end-use applications that can provide added value to coproducts and maximize nutrient use include advanced electricity generation and process heat; greenhouses; and algae, plant, and fish aquaculture. Following the digestion process, diluted wastewater effluent can be used as a nutrient source for hydroponic plant culture in attached greenhouses. Additionally, the use of attached greenhouses can provide enhanced plant growth rates if the available carbon dioxide is captured.

Three new end-use applications are close to commercial deployment that provide the opportunity to generate electricity and recover process heat. They are the Sterling engine, the micro-turbine, and the fuel cell. The Stirling engine has a long history of development, first beginning in the 1800s. A new generation of Stirling engine has been recently perfected which is particularly suited for use as small-scale $(<40-\mathrm{kW})$ gas-fired cogeneration and cooling devices. According to the developers, ${ }^{5}$ these systems offer significant potential advantages over internal combustion engines in efficiency, life expectancy, noise, and emissions. The ability of Stirling engines to maintain higher efficiencies at lower power levels than internal combustion engines could significantly expand the market for small-scale cogeneration.

Like a larger gas turbine, a microturbine is a system based on technology similar to a jet engine. A microturbine usually combines air bearings, lean combustion fuel/air mixtures, and state-of-theart power electronics and control software. Developers state that its benefits include low emissions, low O\&M, little noise, small footprint, no engine oil requirement, and an ability to run on multiple fuels. With an installed cost of $\$ 300-\$ 450 / \mathrm{kW}$, the use of microturbine systems could result in significant capital cost savings compared to the $\$ 1,000 / \mathrm{kW}$ of conventional generation equipment. Micorturbines are available in the range of $<100-\mathrm{kW}$, although the modular capabilities of some suppliers ${ }^{6}$ allow unit integration to provide up to $2-\mathrm{mW}$.

Fuel cells appear to offer a particularly clean and effective method of converting biogas into electricity and process heat. The fuel cell can be described as a galvanic engine or continuous feed battery. It generates electricity from fuel and air without the thermochemical steps required in engines such as turbines. Because there is no combustion and few moving parts, the process has

\footnotetext{
${ }^{5}$ Lane, N; Beale, W. (1996). "Stirling Engines for Gas Fired Micro-Cogen and Cooling." Presented at the Strategic Gas Forum, Detroit, Michigan. Atlanta, GA: Association of Energy Engineers, Inc.

${ }^{6}$ Capstone Turbine Corporation. (1998). Information available at http://www.capstoneturbine.com.
} 
ultra-low emissions, essentially no noise, and high efficiency. Instead of the $20 \%-25 \%$ electrical conversion efficiency from today's engine/generator technologies, fuel cells could produce electricity from biogas at a $45 \%-55 \%$ conversion efficiency, a two-fold increase in productivity. When combined with process heat recovery, overall fuel cell efficiency is greater than $80 \%$. Fuel cells are now being deployed in the $200-\mathrm{kW}$ range, and prototype units are being demonstrated in the $2-\mathrm{mW}$ range.

Wastewater effluent can also be discharged into ponds and used as a growth culture for algae or aquatic plants. Algae are as much as $50 \%$ protein and can be used for many purposes. Currently, algae are produced for animal feed and as a soil amendment. Other algae that can be grown include a lipid-rich algae that can be converted into a liquid diesel fuel substitute, various algae that can be used as natural colorants or dyes, and Spirulina, a super-nutrient containing betacarotene. Some species of duckweed, an aquatic plant that contains 35\%-45\% protein and has properties similar to algae, have phenomenal growth rates when grown in waste effluents. Fresh duckweed has been used as fish food with good results in Bangladesh, and dried duckweed meal has provided an excellent substitute for soy and fish meals in poultry rations in Peru. ${ }^{7}$

According to one report, ${ }^{8}$ a patent was issued for a system using duckweed using a combination of aerobic treatment cells followed by an anaerobic settling zone. A key feature of the system is a lightweight grid of plastic strips that float on the surface of the water to keep the duckweed from drifting. A special harvester was developed to skim off the duckweed in a manner somewhat analogous to an amphibious grain harvester. In addition to the duckweed system, a modular cover for lagoons, ponds, basins, or tanks also is available. One option for covered systems is to install a system for recovering biogas. Since the first full-scale system was constructed in 1989, more than 100 municipal and industrial systems have been installed worldwide.

A combination of these activities could be incorporated on farms with multi-function production systems. "Agri-Plex" would be a more accurate name for such an operation. One demonstration project in Texas $^{9}$ combines a digester and the use of effluents to support the growth of algae and fish. The manures from a 1,000-head cattle herd and from a 180-sow farrow-to-finish operation are first flushed into an anaerobic pit inside an integrated facultative pond. In this approach, the gas collection cover floats just below the water surface rather than on it as current lagoon covering techniques do. The waste stream can produce about 24,000 cubic feet of biogas daily.

After initial treatment, the effluent is discharged to two additional ponds that can be operated in series or in parallel. The first aquaculture pond supports the growth of aquatic plants, initially duckweed, to extract nutrients. The second pond is used as a water source for fish production. The fish culture includes tilapia, which is processed into fish meal or sold as bait fish. The two ponds will eventually be covered with a greenhouse structure to maintain heat during the winter

\footnotetext{
7 Skillicorn, P. et al. (1993). Duckweed Aquaculture: A New Aquatic Farming System for Developing Countries. Washington, DC: The World Bank.

${ }^{8}$ Riggle, D. (1998). “Combining Duckweed and High-Rate Anaerobic Treatments.” Biocycle 39(2): 64-65.

9 Parker, N.; Felder, R. (1996). Alternative Waste Management System with Methane Collection. Lubbock, TX: Texas Tech University. 14 pages.
} 
months, thereby enabling year-round production. Although this system is capital and labor intensive, it provides the greatest potential for economic return.

Other farm residues are digestible. Several research programs have successfully investigated the use of growing energy crops such as aquatic and marine plants, grasses such as napiergrass, ${ }^{10}$ and woody biomass as potential feedstocks for the AD process.

One ambitious project at the University of California-Davis has developed a multi-stage AD system capable of processing rice straw. ${ }^{11}$ This system provides a total mass destruction of $60 \%$, yielding about 5,800 cubic feet of biogas per ton of rice straw. The residual digestate is mainly lignin $(60 \%)$ and ash (40\%), and is highly suitable for being land applied and a soil improver.

Unlike other rice straw projects under discussion like bioethanol, the commercial design currently under consideration is a modular system of 1-mW that processes about 16,000 tons annually. This could make the AD system deployable directly at rice mills, significantly reducing transportation costs. The designers believe that that could pay $\$ 30-\$ 40 /$ ton and still generate electricity at the current retail rate. Given the current California rice straw incentive payment, they believe that net generation costs will be about $\$ 0.02 / \mathrm{kWh}$. The digestion system is also being evaluated for its applicability at the Santa Anita Raceway, where 2,000 horses produce about 325 tons of manure and bedding material daily. Other applications under consideration include paper sludge and vegetable processing wastes.

Extending the $\mathrm{AD}$ process to recover methane has considerable potential beyond the farm to other industries with organic waste streams. Many of these industries use AD as a pretreatment step to lower sludge disposal costs, control odors, and reduce the costs of final treatment at a municipal wastewater treatment facility. From the perspective of the municipal facility, pretreatment effectively expands treatment capacity. Many of these industries already recover methane for displacing on-site energy requirements. Some industries that use AD technology for wastewater treatment include alcohol, baker's yeast, bakery, brewery, candy, canneries, chemical, chocolate, citric acid, coffee, dairy and cheese, distillery, fermentation, fruit juice, fructose production, pulp and paper, pharmaceutical, potato processing, rubber production, sludge liquor, slaughterhouse, soft drinks, starch (barley, corn, wheat), sugar processing, vegetable and fruit, and yeast. The use of AD technology for treating wastewater from industry has grown tremendously during the past decade to the point where there are now more than 1,000 vendorsupplied digestion systems in operation or under construction throughout the world.

Worldwide, more than 115 AD plants now operate or are under construction using MSW or organic industrial waste as their principal feedstock. ${ }^{12}$ The total annual installed capacity is more

\footnotetext{
${ }^{10}$ Wilkie, A.C., et al. (1986). "Enhancement of Anaerobic Methanogenesis from Napiergrass by Addition of Micronutrients." Biomass 11:135-146.

${ }^{11}$ Zhang, R. (24 March 1998). Personal communication. University of California, Davis, CA.

${ }^{12}$ IEA Bioenergy Anaerobic Digestion Activity (1998). Biogas and More! Overview of Systems and Market for Anaerobic Digestion of MSW. Washington, DC: Resource Development Associates.
} 
than 5.6 million tons. This can provide enough energy to heat and cool 2 million American homes. Another $40 \mathrm{AD}$ plants are in the planning phase with an annual capacity of nearly 2.1 million tons. Some 50+ prime technology license holders have proven systems operating at the pilot- or full-scale level (at least 100 tons/year). Waste managers have found that AD provides environmental benefits which allow waste disposal facilities to meet increasingly stringent regulations. Odor and nutrient control is also a major driver in their decision-making processes.

\subsection{Follow The Methane (Slight Return)}

As mentioned in Section 2.7, the methane contained in biogas is a potent greenhouse gas. According to the IPCC, the 100-year GWP of methane is now estimated to be 21 times greater than the GWP of carbon dioxide.

As already shown, with better waste management, methane from manure can be a clean, renewable source of energy. Moreover, based on life cycle cost analysis of proven methane recovery technologies such as slurry, covered lagoons, plug-flow and complete-mix digesters, an unavoidable livestock production liability can become a profit-making asset.

U.S. livestock manures are estimated to emit about 3 million tonnes of methane annually and account for approximately $10 \%$ of the total U.S. methane emissions. ${ }^{13}$ Swine and dairy production facilities account for $80 \%$ of these emissions. There are no formal federal rules or regulations aimed at reducing methane emissions from livestock manures. However, as a portion of the methane emission reduction component of the Climate Change Action Plan announced by President Clinton and Vice-President Gore in 1993, the EPA, DOE, and USDA are expanding a voluntary pollution prevention program with the livestock industry. In the AgSTAR program, a livestock producer will agree to explore profitable methane reduction activities by signing a MOU. Under the MOU, producers will survey farm facilities to identify profitable opportunities to capture and use methane. AgSTAR producers will install systems for the recovery and use of methane only where it is profitable to do so.

Based on the most recent national data ${ }^{14}$ available, a survey of dairy and swine farms in the United States reaffirmed the conclusion that AD is a technology with considerable potential. Assuming that the biogas manufactured at these facilities is used to generate electricity in conventional internal combustion engines, the key factors determining digester profitability are farm size and electricity rates. The inventory of these economically recoverable emissions suggests that $0.426 \mathrm{Tg}$ of methane are potentially recoverable from 2957 dairy and swine farms in 19 states. Pork production represents $61.8 \%$ of recoverable emissions; $60.5 \%$ of potential operations are on dairy farms. The resultant supply curve (Figure 5.1) demonstrates the cumulative effects of deploying digesters in just three key states (North Carolina, California, and

13 U.S. Environmental Protection Agency (1993). "Methane Emissions from Livestock Manure." Chapter 6 in Opportunities to Reduce Anthropogenic Methane Emissions in the United States: Report to Congress. Washington, DC: U.S. Environmental Protection Agency EPA-430-R-93-012; pp. 1-61.

${ }^{14}$ National Agricultural Statistics Service (1993). Census of Agriculture. Washington, DC: U.S. Department of Agriculture,. The report is available at http://www.nass.usda.gov/census/census92/agrimenu.htm. 
Illinois) could recover $78.6 \%$ of these methane emissions. This deployment level could meet the AgSTAR program's goal as defined in the Climate Change Action Plan.

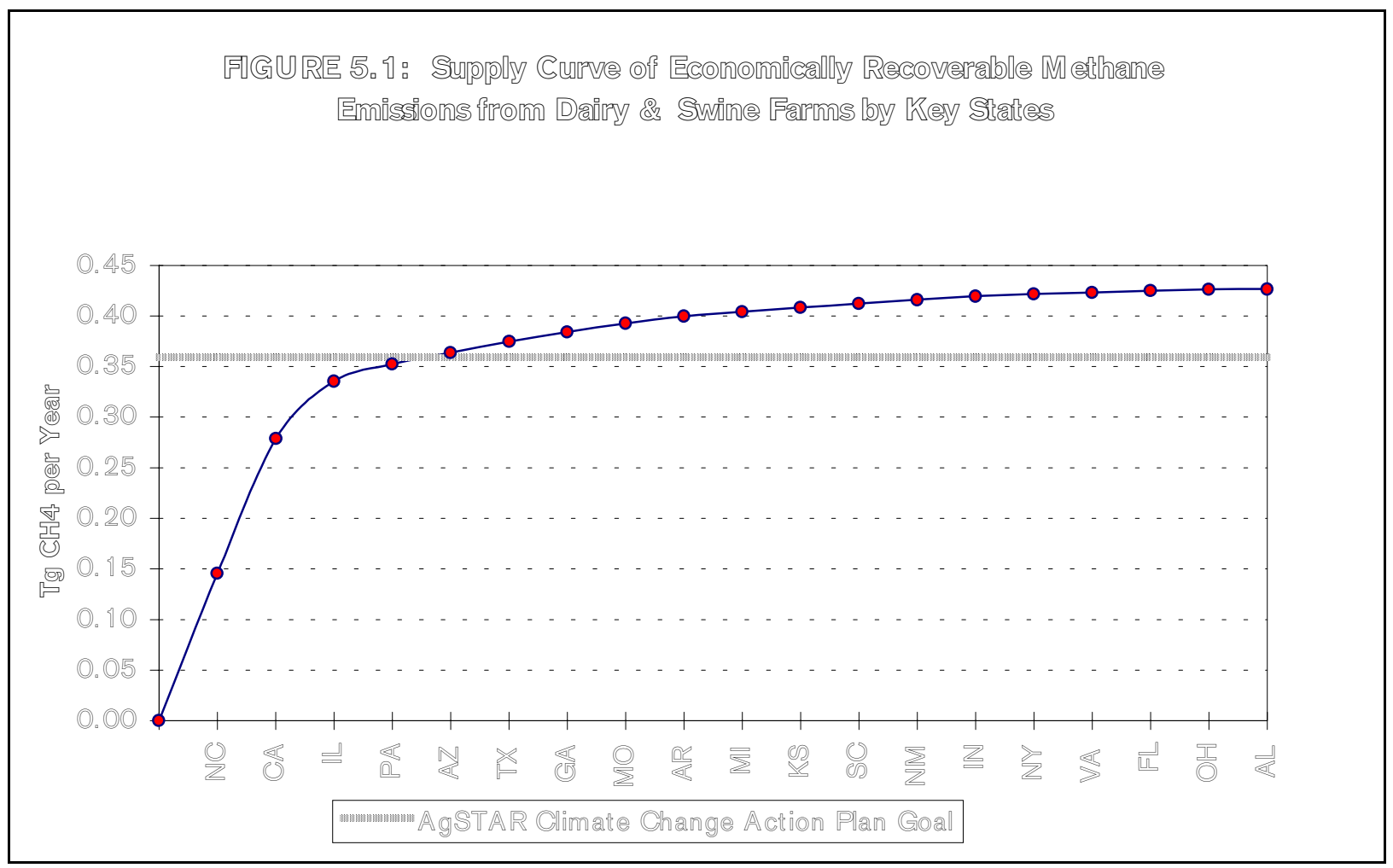

Locating the methane emissions by DOE's Regional Biomass Energy Program area, 80\% are in the Southeast and West (Figure 5.2). However, by number of dairy and swine farms having economically recoverable methane emissions, $60 \%$ are located in the West and only $19 \%$ are located in the Southeast. Pork production represents $62 \%$ of recoverable emissions; $61 \%$ of potential operations are on dairy farms.

Assuming that all recoverable methane emissions are converted into electricity at today's low efficiency rates suggests that slightly more than $165-\mathrm{mW}$ of new capacity could be brought on line. Potentially more important, given methane's current GWP of 21, it represents a reduction in greenhouse gas emissions equivalent to the carbon dioxide emissions from about 3,500-mW of generating capacity from traditional fuels. To give some sense of scale, this represents about half the current biomass-electric generating capacity in the United States. ${ }^{15}$ In the longer term, it is about $20 \%$ of DOE's biomass power program's impact metric for the Year $2010 .{ }^{16}$

\footnotetext{
${ }^{15}$ Energy Information Administration (1996). Annual Energy Review: Renewable Energy. Washington, DC: U.S. Department of Energy. Homepage information available at http://www.eia.doe.gov/emeu/aer/aerren.html.

${ }^{16}$ Office of Utility Technologies (1996) DOE Biomass Power Program Strategic Plan:1996-2015. DOE/GO10096-345. Washington, DC: U.S. Department of Energy.
} 
FIG URE 5.2: Ec o nom ic a lly Recove rable Methane Em issions from

Dairy and Swine Farm s by Regional Biomass Energy Program Area

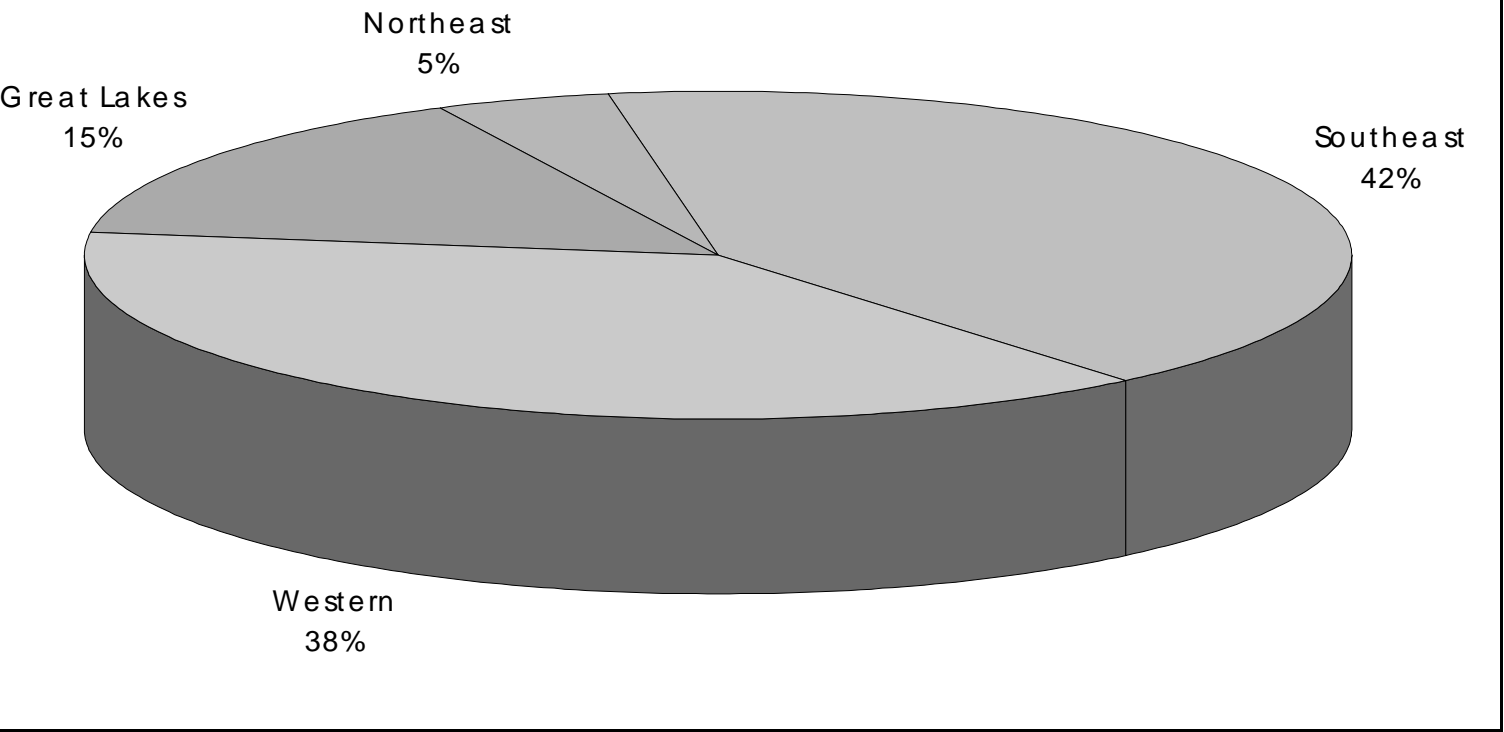

Most voluntary greenhouse gas control programs are not working as effectively as planned. As a result, there has been much recent discussion about the need to impose more stringent greenhouse gas control efforts. Although these may take 2-3 years to be fully developed, broad-based carbon taxes are among the most promising and important of the emerging tools for promoting reductions in carbon emissions. Five European nations have adopted such taxes, but initiatives in the United States, Australia, and the European Union have failed or stalled.

A carbon tax cannot guarantee how great the reduction in emissions will be, but any tax will be excellent for biogas projects because of methane's GWP. Some economists ${ }^{17}$ have made a range of estimates for the effect various carbon taxes would have. The firmest conclusion that emerges from their work is that the tax would have to be high, some $\$ 100 /$ ton of carbon or about $\$ 367 /$ ton of carbon dioxide, if it were to reduce emissions substantially in the long run. A $\$ 100 /$ ton carbon tax would raise the current price of crude oil (around $\$ 20 /$ barrel) by about two-thirds. The tax would have to be this high in part because economic growth will, in the absence of abatement policy, increase emissions over time.

Some planning units at the DOE currently use a placeholder of $\$ 15 /$ ton of carbon dioxide (\$55/ton carbon) in their current planning models. Such a modest carbon tax would provide a value adder of about $\$ 0.113 / \mathrm{kWh}$ to an AD project. All forms of methane recovery projects would then become very attractive financially and might double the number of economically deployable farm digesters.

\footnotetext{
${ }^{17}$ Baron, R. (1996). Policies and Measures for Common Action Working Paper. Economic/Fiscal Instruments: Taxation (i.e., carbon/energy). Paris, France: International Energy Agency.
} 
There is much discussion about the United States' ability to reduce its atmospheric carbon emissions. The most widely discussed evaluation is the so-called "Five-Lab" study, ${ }^{18}$ which calculated the carbon reduction potentials of cellulosic ethanol and biomass power. Depending on the amount of a hypothetical carbon tax, these two biomass technologies could reduced emissions by 12 million tonnes (no tax) to 30 million tonnes ( $\$ 50 /$ tonne tax).

An equally plausible scenario can be created for the carbon reduction potential of recovering biogas from four sources: landfills, farms, municipalities, and industries. By 2005, around 40 trillion Btu of biogas could be recovered, which would reduce carbon equivalent emissions by 4.5 million tonnes. By 2015, more than 240 trillion Btu of biogas could be recovered, which would reduce carbon equivalent emissions by more than 27 million tonnes. Other uncalculated carbon benefits would result from substituting organic digestate coproducts for traditional chemical fertilizers. Because this biogas is recovered from zero and negative value feedstocks, technology could likely be deployed without a carbon tax.

When other wastewater sludges and a variety of other organic materials are added in, the energy potential reaches a fairly high percentage of national energy use. Some researchers ${ }^{19}$ believe that about 7,000 trillion Btu of biogas (7 quads) could be recovered in the United States from digesting waste feedstocks, which would reduce carbon equivalent emissions by more than 790 million tonnes. Digesting terrestrial biomass in the United States could provide around 22,000 trillion Btu of biogas (22 quads), which would reduce carbon equivalent emissions by 2.5 billion tonnes.

Unfortunately neither the "Five-Lab" nor the later "Eleven-Lab" study ${ }^{20}$ make any accounting for this potential, likely because the United States has no federal policy on biogas recovery projects. This should be contrasted to the range of developed and transitional economy countries that do: China, Denmark, Germany, India, Sweden, and Zaire, to name a few. For example, Denmark's commitment to AD increased with the presentation of a 1996 initiative by the Ministry of Environment and Energy that will double current biogas recovery by the year 2000, then triple it by the year 2005. A key issue is the development of better policy options for the recovery of biogas in the United States. It is not a failure of planning, but a failure of vision that will limit the deployment of AD technology in the United States.

\footnotetext{
${ }^{18}$ Interlaboratory Working Group (1997). Scenarios of U.S. Carbon Reductions: Potential Impacts of Energy Technologies by 2010 and Beyond. Lawrence Berkeley National Laboratory, Berkeley, CA, and Oak Ridge National Laboratory, Oak Ridge, TN. Jointly issued as LBNL-40533 and ORNL-444. The report is available at http://www.ornl.gov.ORNL/Energy_Eff/CON444.

${ }^{19}$ Chynoweth, D.; Owens, J; Legrand, R. (1997). "Renewable Methane from the Anaerobic Digestion of Biomass.” ASAE Publication 976077. Presented at the 1997 ASAE Annual International Meeting, Minneapolis, MN, 10-14 August.

${ }^{20}$ Technology Opportunities to Reduce U.S. Greenhouse Gas Emissions. (1997). The report is available at http://www.ornl.gov/climate_change/climate.htm.
} 


\subsection{SYSTEM DESIGNER/INSTALLER CONTACTS}

Agri-Biosystems, Inc.

Dr. Rich Vetter

PO Box 5144

Elgin, IL 60121

tel: $\quad 847.888 .7854$

fax: $\quad 847.888 .1484$

AgriWaste Technology, Inc.

Dr. L.M. Safley, Jr., PE

700-108 Blue Ridge Road

Raleigh, NC 27606

tel: $\quad 919.829 .0014$

fax: $\quad 919.829 .1507$

Agway Farm Research Center

Dr. Stan Weeks

6978 New York Route 80

Tully, NY 13159

tel: $\quad 315.683 .5700$

fax: $\quad 315.683 .9276$

Commercial Engineering Corp.

Skip Newton

2890 Dundee Road

Northbrook, IL 60062-2052

tel: $\quad 847.205 .1112 \times 21$

fax: $\quad 847.205 .1119$

BioRecycling Technologies, Inc.

Jim Hamamoto

6101 Cherry Avenue

Fontana, CA 92336

tel: $\quad 909.899 .2982$

fax: $\quad 909.899 .9519$

Charles R. Browning \& Associates

Suite 102

3008 Anderson Drive

Raleigh, NC 27609-7744

tel: $\quad 919.782 .3432$

fax: $\quad 919.781 .7796$
Duke Engineering \& Services

Harold, L. Backman, PE

PO Box 1004

Charlotte, NC 28210-1004

tel: $\quad 704.382 .8570$

fax: 704.373 .6970

email: hbackma@duke-engineering.com

ENTEK BioSystems, LC

Bob Urell

PO Box 372

Smithfield, VA 23431-0372

tel: $\quad 757.365 .4155$

fax: $\quad 757.657 .6500$

email: entekbio@aol.com

Enviroenergy Systems, Inc.

Paul Serbu

7860 Woodridge Drive

Gainesville, VA 22065

tel: $\quad 703.754 .2042$

fax: $\quad 703.476 .0414$

Environmonics, Inc.

Richard Mattocks

PO Box 371

Riverdale, NY 10471

tel: $\quad 718.884 .6740$

fax: $\quad 718.884 .6726$

email: utter@compuserve.com

Environmental Fabrics, Inc.

Dennis Schanklin

85 Pascon Court

Gaston, SC 29053

tel: $\quad 803.551 .5700$

fax: $\quad 803.551 .5701$ 
Environmental Treatment Systems

Charles Ross, PE

Suite 100

1500 Wilson Way

Smyrna, GA 30082

tel: $\quad 770.384 .0602$

Linde/Lotepro Corporation

Gordon W. Kumke

Mt. Pleasant Corporate Center

115 Stevens Avenue

Valhalla, NY 10595

tel: $\quad 914.749 .5204$

fax: 914.747 .3422

email: fs

Oswald Green, Inc.

Dr. William J. Oswald, PE

1081 St. Francis Drive

Concord, CA 94518

tel: $\quad 510.689 .3727$

fax: $\quad 510.682 .2093$

Perennial Energy Corporation

Ted Landers

Route 1 Box 645

West Plains, MO 65775

tel: $\quad 417.256 .2002$

fax: $\quad 417.256 .2801$

Resource Conservation Management, Inc.

Mark Moser

PO Box 4715

Berkeley, CA 94704

tel: $\quad 510.658 .4466$

fax: $\quad 510.658 .2729$

Safe Environmental Inventions, Inc.

Mark Thomas

Suite 610

1155 North State Street

Bellingham, WA 98225

tel: $\quad 360.647 .2800$

fax: $\quad 360.647 .5178$

e-mail: S.E.I@worldnet.att.net
Sharp Energy, Inc.

Roy Sharp

20174 Road 140

Tulare, CA 93274

tel: $\quad 209.688 .2051$

fax: $\quad 209.688 .2051$

NOTE: This should not be considered an exhaustive list of available consultants qualified to design or install on-farm anaerobic digesters in the US. There are certainly consultants not identified in this listing who may be able to provide this service. The exclusion of any such consultant is not an indication of lack of service quality. 


\subsection{OTHER CONTACTS}

\section{DEPARTMENT OF ENERGY}

N. Michael Voorhies

Regional Biomass Energy Program

Office of Fuels Development, EE-31

U.S. Department of Energy

1000 Independence Avenue, SW

Washington, DC 20585

tel: $\quad 202.586 .1480$

fax: $\quad 202.586 .8134$

email: michael.voorhies@ee.doe.gov

\section{RBEP MANAGERS}

GREAT LAKES

Frederick J. Kuzel

Council of Great Lakes Governors

35 East Wacker Drive, Suite 1850

Chicago, IL 60601

tel: $\quad 312.407 .0177$

fax: $\quad 312.407 .0038$

email: fkuzel@cglg.org

web-site: http://www.cglg.org/projects/biomass

States served: Illinois, Indiana, Iowa,

Michigan, Minnesota, Ohio, and Wisconsin.

NORTHEAST

Richard Handley

CONEG Policy Research Center, Inc.

400 North Capitol Street, NW

Suite 382

Washington, DC 20001

tel: $\quad 202.624 .8454$

fax: $\quad 202.624 .8463$

email: rhandley@capital.net

web-site: http://www.nrbp.org

States served: Connecticut, Delaware, Maine, Maryland, Massachusetts, New Hampshire, New Jersey, New York, Pennsylvania, Rhode Island, and Vermont.
PACIFIC NORTHWEST \& ALASKA

Jeffrey James

Seattle Support Office

U.S. Department of Energy

800 Fifth Avenue, Suite 3950

Seattle, WA 98104

tel: $\quad 206.553 .2079$

fax: $\quad 206.253 .2000$

email: jeffrey.james@hq.doe.gov

States served: Alaska, Idaho, Oregon, Montana, and Washington.

\section{SOUTHEAST}

Phillip C. Badger, P.E.

Tennessee Valley Authority

CEB 5C

Muscle Shoals, AL 35660

tel: $\quad 256.386 .3086$

fax: $\quad 256.386 .2499$

email: pcbadger@tva.gov

States served: Alabama, Arkansas, District of Columbia, Florida, Georgia, Kentucky, Louisiana, Mississippi, Missouri, North

Carolina, South Carolina, Tennessee, Virginia, and West Virginia.

\section{WESTERN \\ Jeff Graef}

Nebraska Energy Office

PO Box 81671

Lincoln, NE 68509-5085

tel: $\quad 402.471 .2867$

fax: $\quad 402.471 .3064$

email: jgraef@mail.state.ne.us

web-site: http://www.westbioenergy.org

States served: Arizona, California, Colorado, Kansas, Nebraska, Nevada, New Mexico, North Dakota, Oklahoma, South Dakota, Texas, Utah, and Wyoming. 
EPA

Kurt F. Roos

AgSTAR Program Director

Mail Stop 6206-J

401 M Street, SW

Washington, DC 50460

tel: $\quad 202.564 .9041$

fax: $\quad 202.564 .9569$

email: roos.kurt@epa.gov

\section{USDA/NRCS}

Leland M. Saele, PE

Environmental Engineer, AgSTAR

Natural Resources Conservation Service

405 Bland Road

Raleigh, NC 27609

tel: $\quad 919.873 .2170$

fax: $\quad 919.873 .2157$

email: 1saele@nc.nrcs.usda.gov

NOTE: NRCS has developed a pilot AgSTAR engineering position in Raleigh to better equip NRCS personnel with the technical support needed to identify and develop cost-effective methane recovery projects on livestock farms.

Wayne Bogovich

NRCS Area Engineer

North Ridge Building

Suite 105

1590 North Center Avenue

Somerset, PA 15501

tel: $\quad 814.445 .3141$

fax: $\quad 814.445 .2044$

\section{UNIVERSITIES}

Dr. Cady R. Engler, PE

Associate Professor

Department of Agricultural Engineering

Texas A\&M University

College Station, TX 77843

tel: $\quad 409.845 .3685$

fax: $\quad 409.847 .8627$

email: c_engler@tamu.edu
Dr. Clifford B. Fedler, PE

Professor

Department of Civil Engineering

PO Box 41023

Texas Tech University

Lubbock, TX 79409-1023

tel: $\quad 806.742 .2801 \times 255$

fax: $\quad 806.742 .3449$

email: cfedler@coe.ttu.edu

Dr. Sambbhunath (Sam) Ghosh

Professor

Department of Civil Engineering

3220 Merrill Engineering Building

University of Utah

Salt Lake City, UT 84112

tel: $\quad 801.581 .6937$

fax: $\quad 801.581 .8692$

Dr. Robert E. Graves, PE

Professor of Agricultural Engineering

The Pennsylvania State University

201 Agricultural Engineering Building

University Park, PA 16802-1909

tel: $\quad 814.865 .7155$

fax: $\quad 814.863 .1031$

email: reg2@psu.edu

Dr. F. Bailey Green

Applied Algae Research Group

Environmental Engineering \& Health

Sciences Laboratory

University of California, Berkeley

1371 S. 46th Street, Bldg. 112, \#3580

Richmond, CA 94804-4608

tel: $\quad 510.231 .5682$

fax: $\quad 510.231 .9500$

email:_fbgreen@socrates.berkeley.edu

Dr. Andrew G. Hashimoto

Professor \& Head

Bioresource Engineering

Gilmore Hall 116

Oregon State University

Corvallis, OR 91331-3906

tel: $\quad 503.737 .2041$

fax: $\quad 503.737 .2082$ 
Dr. Jason C.H. Shih

Professor, Biotechnology

Department of Poultry Science

PO Box 7608

North Carolina State University

Raleigh, NC 27685-7608

tel: $\quad 919.515 .5521$

fax: $\quad 919.515 .2625$

email: jason_shih@ncsu.edu

Dr. Shihwu (Wu) Sung, PE

Director Anaerobic Systems Engineering

Department of Civil Engineering

394 Town Engineering Building

Iowa State University

Ames, IA 50011-3232

tel: $\quad 515.294 .3896$

fax: $\quad 515.294 .8216$

email: sung@ccelab.iastate.edu

Dr. Ann C. Wilkie

Associate Professor

Soil and Water Science Department

University of Florida

PO Box 110960

Gainesville, FL 32611-0960

tel: $\quad 352.392 .8699$

fax: $\quad 352.392 .7008$

email: acwi@gnv.ifas.ufl.edu

Dr. Douglas W. Williams

Professor

Agricultural Engineering Department

California Polytechnic State University

San Luis Obispo, California 93407

tel: $\quad 805.756 .9108$

fax: $\quad 805.756 .2626$

Dr. Ruihong Zhang

Assistant Professor

Biological \& Ag Engineering Department

3046 Bainer Hall

University of California

Davis, CA 95616

tel: $\quad 916.754 .9530$

fax: $\quad 916.752 .2630$

email: rhzhang.ucdavis.edu

\section{ELECTRONIC RESOURCES}

Using the services of Center for Renewable Energy and Sustainable Technology (CREST), the U.S. Department of Energy's Regional Biomass Energy Program and the International Energy Agency Bioenergy's AD Activity have developed an e-mail list intended for the discussion of $\mathrm{AD}$ as a sustainable energy resource. Currently, more than 150 subscribers on four continents are on-line using the free service.

For those of you not familiar with e-mail lists, they can be an excellent way to ask a question or to raise an issue with like-minded individuals. In this case, you just address your e-mail message to "digestion@ crest.org" (omitting the "..."), and then simply write your message.

To subscribe, send a message to "majordomo@crest.org" with the line "subscribe digestion <your email address> in the message body (not the Subject: line).

For example:

subscribe digestion xyz@123.com.

Once you receive confirmation of your subscription you will receive additional information on the other available list commands. 


\section{REPORT DOCUMENTATION PAGE}

Form Approved OMB NO. 0704-0188

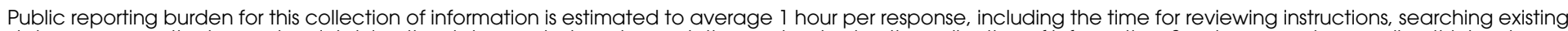

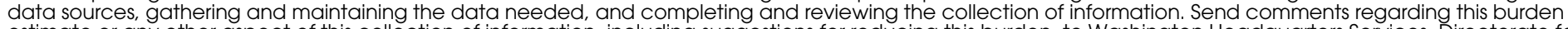

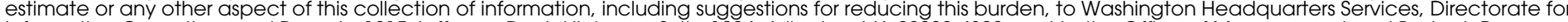

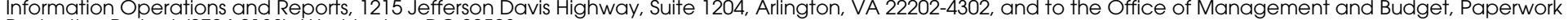
Reduction Project (0704-0188), Washington, DC 20503.
1. AGENCY USE ONLY (Leave blank)
2. REPORT DATE
3. REPORT TYPE AND DATES COVERED
September 1998
NREL Subcontract Report

4. TITLE AND SUBTITLE

Methane Recovery from Animal Manures The Current Opportunities Casebook

6. AUTHOR(S)

P. Lusk

7. PERFORMING ORGANIZATION NAME(S) AND ADDRESS(ES)

Resource Development Associates

240 Ninth Street, NE

Washington, DC 20002-6110

9. SPONSORING/MONITORING AGENCY NAME(S) AND ADDRESS(ES)

National Renewable Energy Laboratory

1617 Cole Blvd.

Golden, CO 80401-3393

5. FUNDING NUMBERS

Task \#:BF8880101

8. PERFORMING ORGANIZATION REPORT NUMBER

10. SPONSORING/MONITORING AGENCY REPORT NUMBER

NREL/SR-580-25145

11. SUPPLEMENTARY NOTES

NREL Technical Monitor: A.E. Wiselogel

12a. DISTRIBUTION/AVAILABILITY STATEMENT

National Technical Information Service

U.S. Department of Commerce

5285 Port Royal Road

Springfield, VA 22161

13. ABSTRACT (Maximum 200 words)

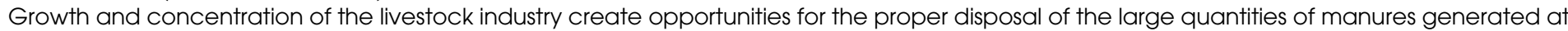

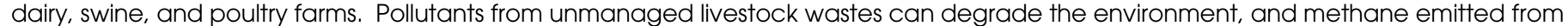

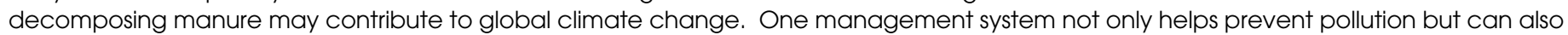

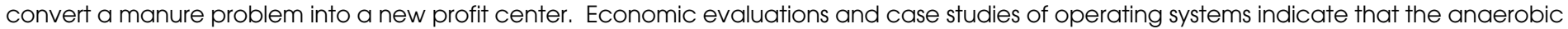

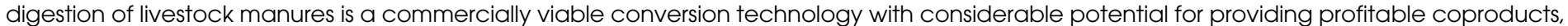

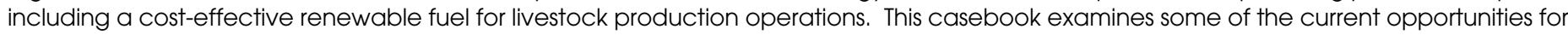
recovering methane from anaerobic digestion animal manures.

14. SUBJECT TERMS

15. NUMBER OF PAGES

anaerobic digestion, animal manure, bioconversion technology, engineering economy, environmental quality, pollution prevention, sustainable development

16. PRICE CODE

17. SECURITY CLASSIFICATION OF REPORT

18. SECURITY CLASSIFICATION OF THIS PAGE
19. SECURITY CLASSIFICATION OF ABSTRACT
20. LIMITATION OF ABSTRACT

.

NSN 7540-01-280-5500

Standard Form 298 (Rev. 2-89)

Prescribed by ANSI Std. Z39-18 